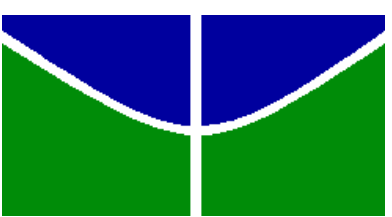

UNIVERSIDADE DE BRASÍLIA

FACULDADE DE EDUCAÇÃO

PROGRAMA DE PÓS-GRADUAÇÃO EM EDUCAÇÃO

\title{
JOGOS DE REFLEXÃO PURA COMO FERRAMENTA LÚDICA PARA A APRENDIZAGEM MATEMÁTICA
}

VIRGÍNIA PERPETUO GUIMARÃES PIN

BRASÍLIA

2016 
UNIVERSIDADE DE BRASÍLIA - UNB

FACULDADE DE EDUCAÇÃO - FE

PROGRAMA DE PÓS-GRADUAÇÃO EM EDUCAÇÃO - PPGE

\section{JOGOS DE REFLEXÃO PURA COMO FERRAMENTA LÚDICA PARA A APRENDIZAGEM MATEMÁTICA}

VIRGÍNIA PERPETUO GUIMARÃES PIN

Dissertação apresentada ao Programa de Pósgraduação em Educação da Faculdade de Educação, Universidade de Brasília - PPGE/FE/UnB, sob orientação do Prof. Dr. Antônio Villar Marques de Sá, como requisito à obtenção do título de Mestre em Educação.

BRASÍLIA 
UNIVERSIDADE DE BRASÍLIA - UNB

FACULDADE DE EDUCAÇÃO - FE

PROGRAMA DE PÓS-GRADUAÇÃO EM EDUCAÇÃO - PPGE

DISSERTAÇÃO DE MESTRADO

\title{
JOGOS DE REFLEXÃO PURA COMO FERRAMENTA LÚDICA PARA A APRENDIZAGEM MATEMÁTICA
}

\author{
VIRGÍNIA PERPETUO GUIMARÃES PIN
}

\section{Comissão Examinadora:}

Prof. Dr. Antônio Villar Marques de Sá (Orientador)

Faculdade de Educação da Universidade de Brasília (FE/UnB)

Prof. Dr. Cristiano Alberto Muniz (Membro interno)

Faculdade de Educação da Universidade de Brasília (FE/UnB)

Prof. Dra. Regina da Silva Pina Neves (Membro externo)

Instituto de Exatas da Universidade de Brasília (IE/UnB)

Prof. Dra. Josinalva Estácio Menezes (Suplente)

Instituto de Exatas da Universidade de Brasília (IE/UnB)

BRASÍLIA

2016 
Esta pesquisa é dedicada aos professores que buscam meios de atrair os alunos para o ensino e a aprendizagem, tornando o processo prazeroso e significativo. 


\title{
AGRADECIMENTOS
}

\author{
A Deus, \\ Por me dar a capacidade e iluminar o meu caminho. \\ Ao meu marido, \\ Por me fazer acreditar a cada dia em meu potencial.
}

À minha família,

Por estar sempre ao meu lado.

Ao meu orientador,

Por aceitar me acompanhar nesta trajetória.

Aos colegas e ao professor da turma de Laboratório de Pesquisa do ano de 2015, Por me ajudarem a encontrar o foco da minha pesquisa.

Aos componentes das bancas de qualificação e defesa, Por suas ricas considerações e sugestões na construção desta dissertação.

À direção e professora da escola,

Por disponibilizarem tempo e espaço para a aplicação da pesquisa aqui descrita. 


\section{RESUMO}

O ambiente escolar deve ser acolhedor, interessante e provocativo. Uma forma de estimular a aprendizagem matemática e o raciocínio dos alunos da educação infantil e despertar o seu interesse pela aprendizagem é utilizando instrumentos lúdicos, e em especial os jogos. Os Jogos de Reflexão Pura são um tipo de jogo de estratégia construído sobre bases matemáticas, mas que não apresentam um conteúdo matemático específico e oferecem diferentes situações e possibilidades que estimulam o pensamento e o raciocínio. Estes jogos são capazes de estimular as bases necessárias para a aprendizagem matemática da criança. Desta forma, esta pesquisa teve como objetivo compreender o os Jogos de Reflexão Pura na aprendizagem matemática da educação infantil. Esta pesquisa foi realizada com alunos do $2^{\circ}$ período da educação infantil e sua base foi o desenvolvimento de jogos, observando a relação dos alunos com eles e como isto influencia a sua aprendizagem matemática. Para isso foram utilizados os Jogos de Reflexão Pura: Jogo da Velha, Jogo da Memória, Cara a Cara, Mancala e Pontinhos. Os conceitos centrais estudados foram o de ludicidade e aprendizagem. Dentro destes se inseriram os jogos, o conceito de Jogos de Reflexão Pura e a aprendizagem matemática. Foram utilizados como referências principais os autores Piaget (1974, 1979, 1983, 1990, 2015), Kishimoto (2000), Macedo, Petty, Passos (2005), Huizinga (2007), Nunes e Bryant (1997), Muniz (2010) e Kamii (2012), dentre outros. Esta pesquisa qualitativa apresentou características da pesquisa-ação. Foram utilizados como instrumentos de construção de informação a observação, a entrevista e a análise das atividades desenvolvidas. Ao final da pesquisa, observou-se um crescimento dos alunos com relação à matemática, concluindo que os Jogos de Reflexão Pura podem contribuir para esta aprendizagem na educação infantil de maneira lúdica. Espera-se que essa pesquisa contribua para a aprendizagem dos alunos da educação infantil, proporcionando uma educação matemática lúdica.

Palavras-chave: Ludicidade, aprendizagem, jogos, matemática, educação infantil. 


\begin{abstract}
The school environment should be welcoming, interesting and provocative. One way to stimulate the mathematical learning and the reasoning of the students of the child education and to induce their interest by the learning is using playful instruments, especially the games. Pure Reflection Games are a type of strategy game built on mathematical bases, but which no specific mathematical content and offer different situations and possibilities that stimulate thinking and reasoning. These games are able to stimulate the necessary bases for the mathematical learning of the child. Thus, this research aimed to understand the Pure Reflection Games in the mathematical learning of children's education. This research was carried out with students of the 2nd period of early childhood education and its basis was the development of games, observing the relationship of students with them and how this influences their mathematical learning. For this were used the Pure Reflection Games: Tic tac toe, Memory Game, Guess Who, Mancala and Pontinhos. The central concepts studied were playfulness and learning. These included the games, the concept of Pure Reflection Games and the mathematical learning. As references were used the authors Piaget (1974, 1979, 1983, 1990, 2015), Kishimoto (2000), Macedo, Petty, Passos (2005), Huizinga (2007), Nunes and Bryant and Kamii (2012), among others. This qualitative research presented characteristics of the action-research. Observation, interviewing and analysis of the activities developed were used as instruments of information construction. At the end of the research, we observed a growth of the students in mathematics, concluding that the Pure Reflection Games can contribute to this learning in the children's education in a playful way. It is hoped that this research contributes to the learning of children's education students, providing a playful mathematical education.
\end{abstract}

Key words: Ludicidade, learning, games, mathematics, early childhood education. 
“A criança procura o jogo como uma necessidade e não como distração. É pelo jogo que a criança se revela. As suas inclinações boas ou más. A sua vocação, as suas habilidades, o seu caráter, tudo que ela traz latente no seu eu em formação, torna-se visível pelo jogo e pelos brinquedos, que ela executa".

Tizuko Morchida Kishimoto 1993, p. 106 


\section{LISTA DE ILUSTRAÇÕES}

Figura 1: Avaliação das competências e dificuldades conceituais sobre número, grupo CIMETE. .54

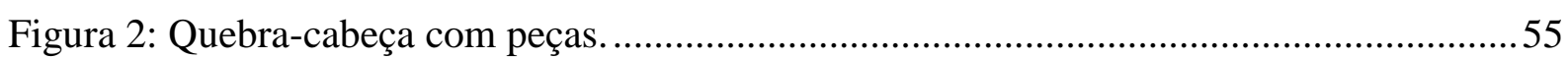

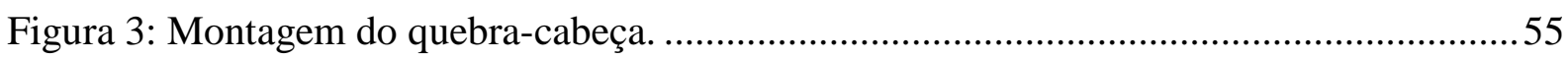

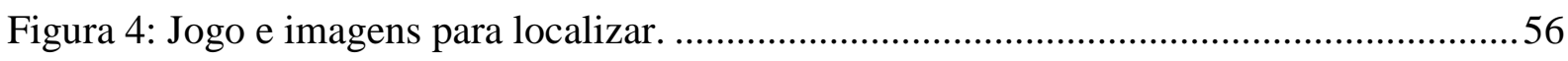

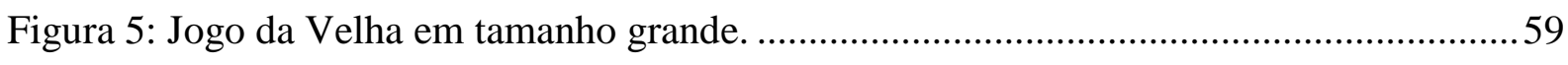

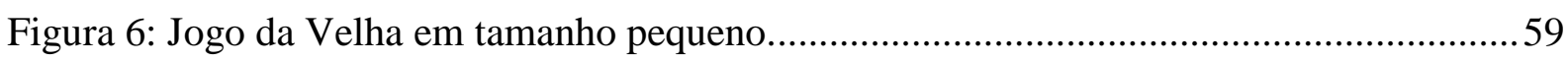

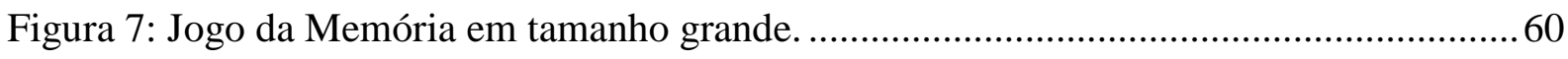

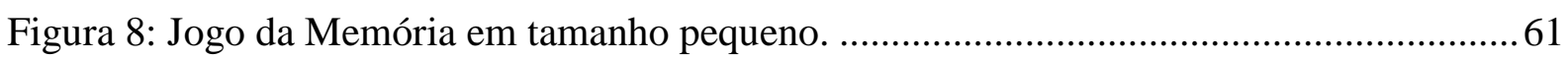

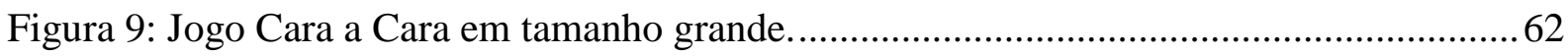

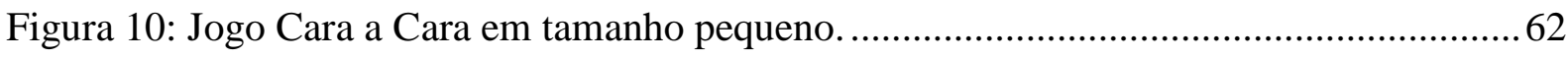

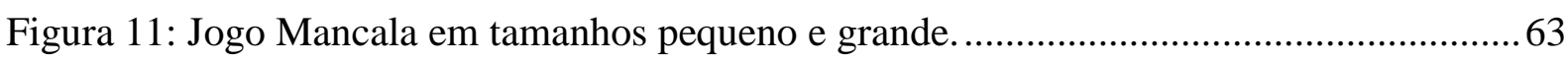

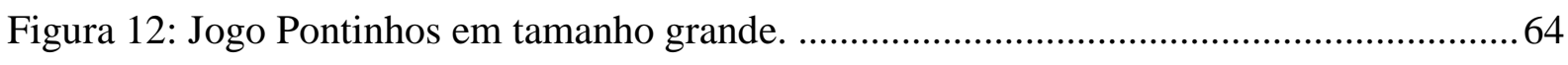

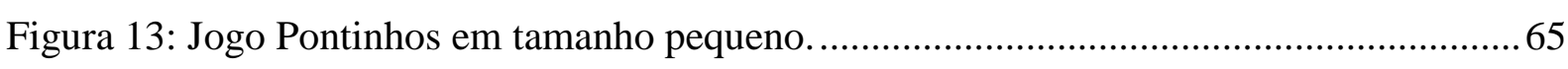

Figura 14: Desenho do jogo Cara a Cara feito pela aluna Rafaela......................................... 84

Figura 15: Desenho do jogo Cara a Cara feito pela aluna Sandra......................................... 84

Figura 16: Desenho do Jogo da Memória feito pela aluna Mônica........................................ 85

Figura 17: Desenho do Jogo da Memória feito pelo aluno Sérgio. ......................................... 85

Figura 18: Desenho do jogo Pontinhos feito pelo aluno Davi................................................ 86

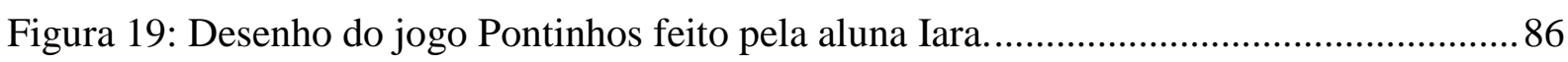




\section{LISTA DE QUADROS}

Quadro 1: Resultado da pesquisa bibliográfica realizada em 2015 .....................................21

Quadro 2: Resultado da pesquisa bibliográfica realizada em 2016.......................................23

Quadro 3: Resultado da pesquisa em anais do Enem. ........................................................... 24

Quadro 4: Resultado da pesquisa em anais do Sipem........................................................25

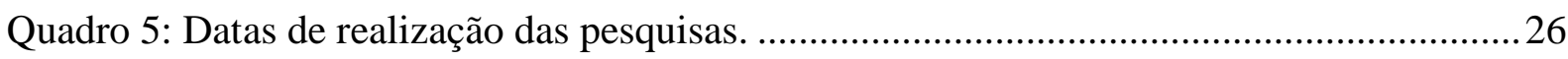

Quadro 6: Quadro de coerência da pesquisa. ....................................................................50

Quadro 7: Comparação das habilidades esperadas e estimuladas pelos jogos. ...................... 101 


\section{LISTA DE SIGLAS}

BCE - Biblioteca Central do Estudante

BDTD - Biblioteca Digital de Teses e Dissertações

Bireme - Biblioteca Regional de Medicina

Enem - Encontro Nacional de Educação Matemática

Fapesp - Fundação de Amparo à Pesquisa do Estado de São Paulo

Ibict - Instituto Brasileiro de Informação em Ciência e Tecnologia

Sbem - Sociedade Brasileira de Educação Matemática

Scielo - Scientific Electronic Library Online

Sipem - Seminário Internacional de Pesquisa em Educação Matemática

UnB - Universidade de Brasília

Unicamp - Universidade Estadual de Campinas 


\section{SUMÁRIO}

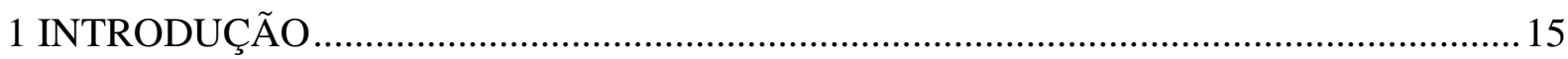

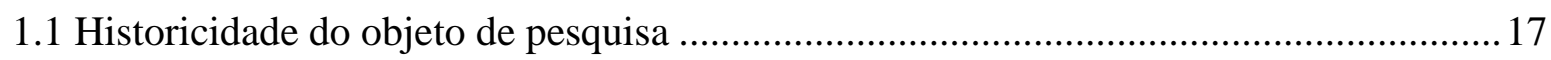

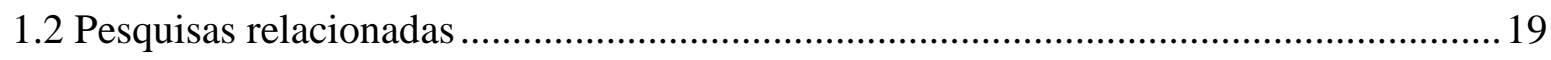

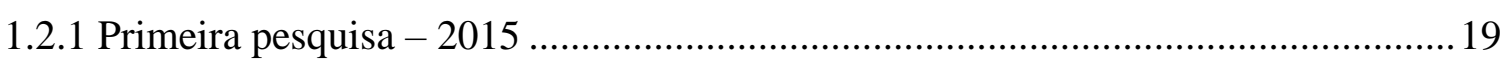

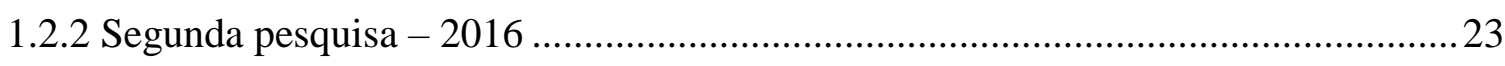

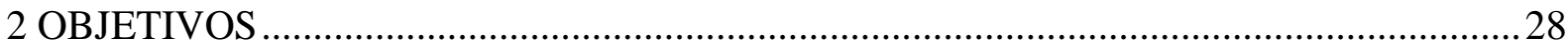

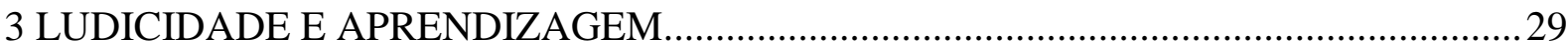

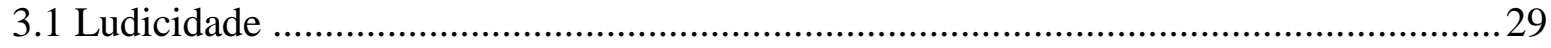

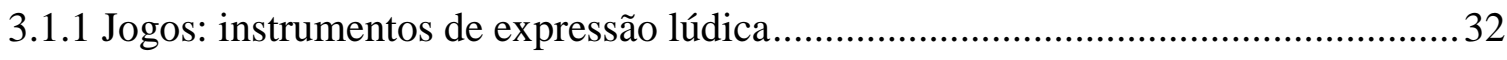

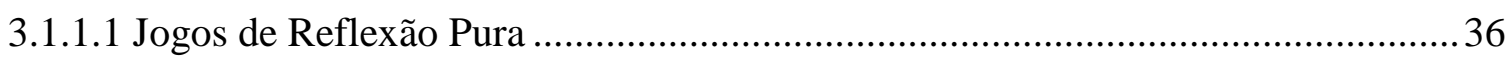

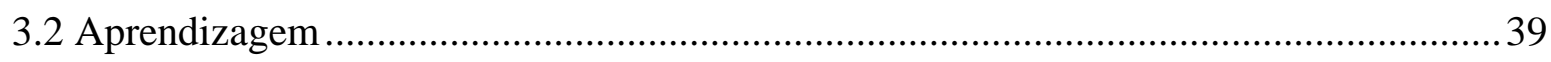

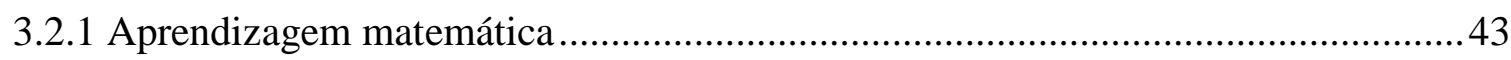

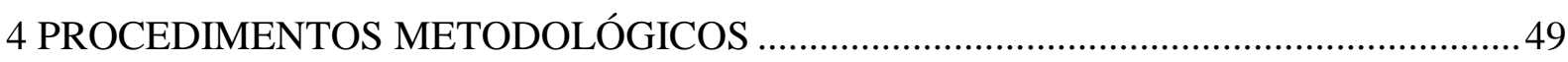

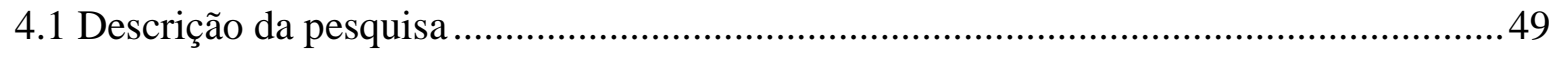

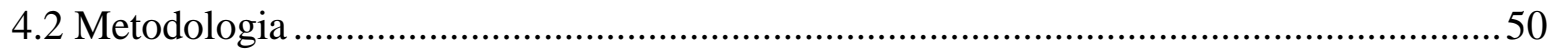

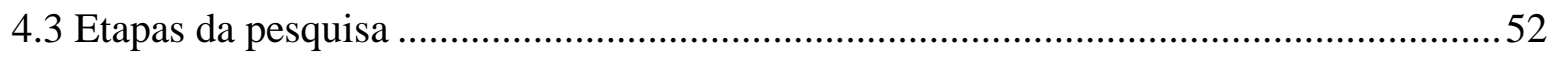

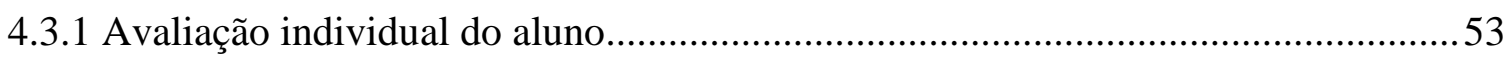

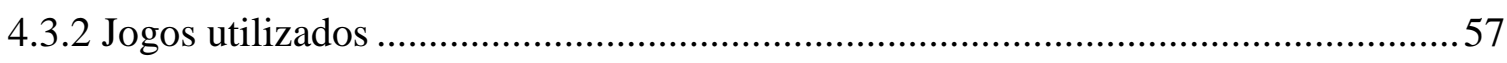

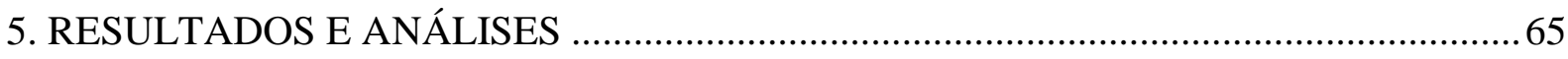

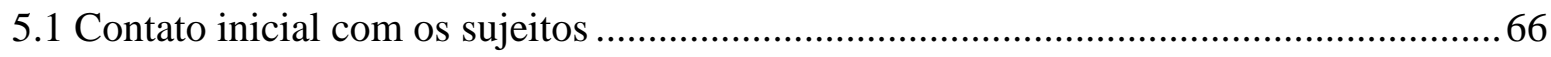

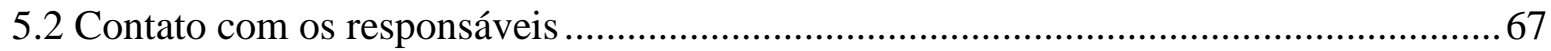

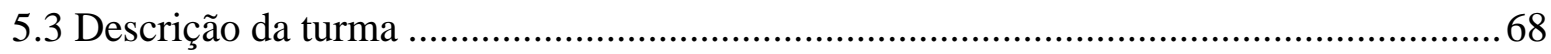

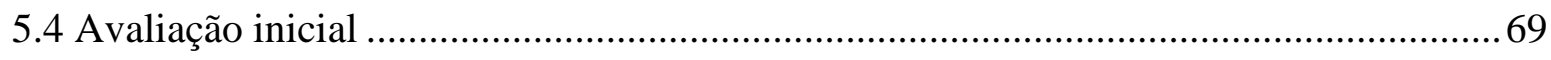

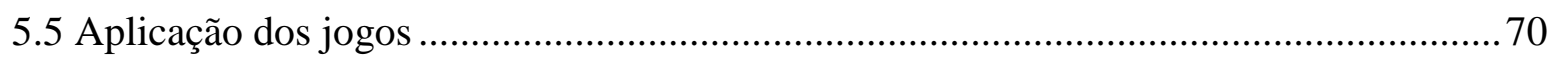

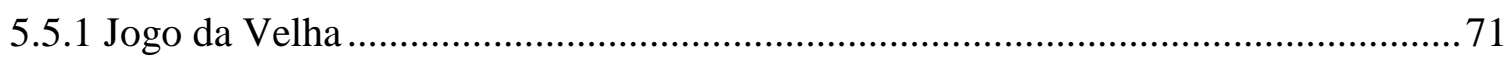

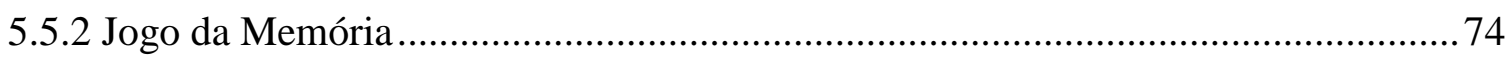

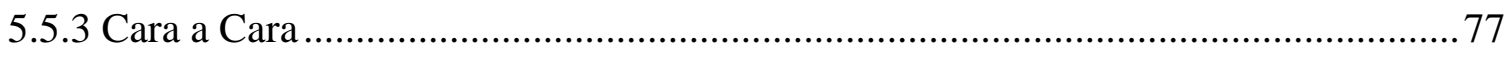

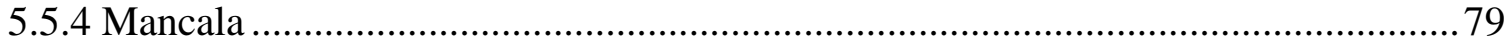

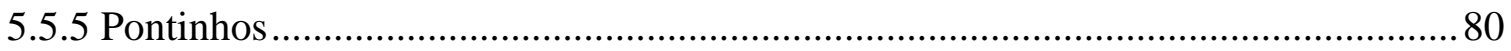




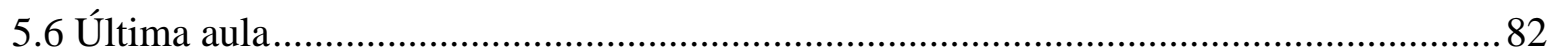

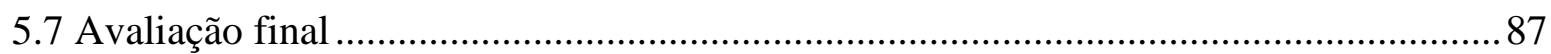

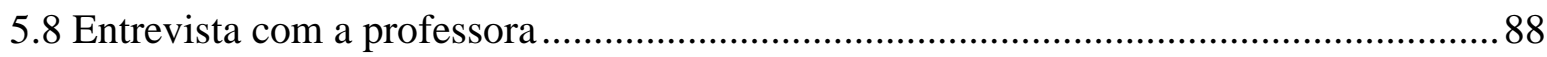

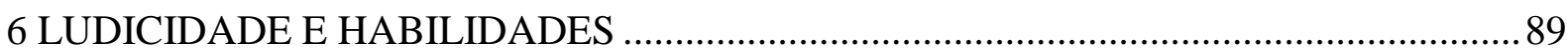

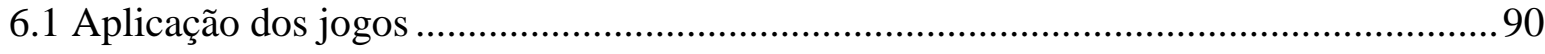

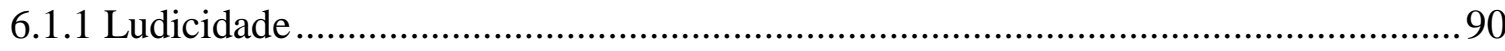

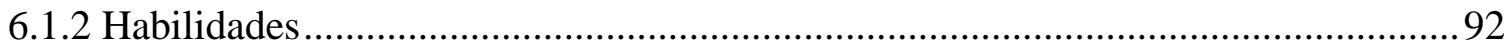

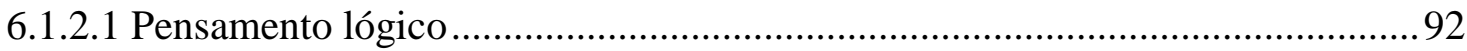

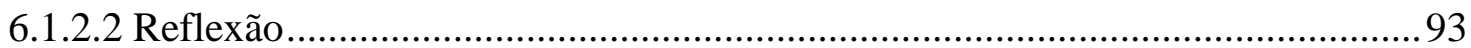

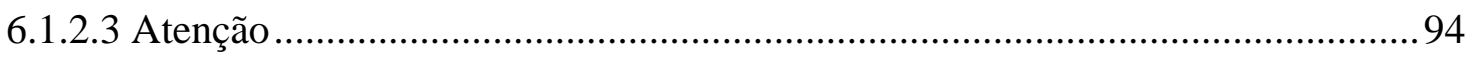

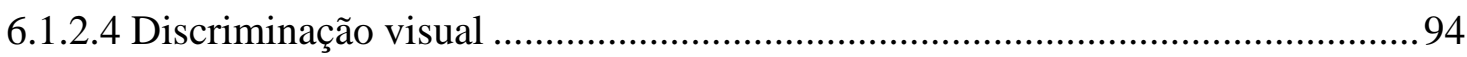

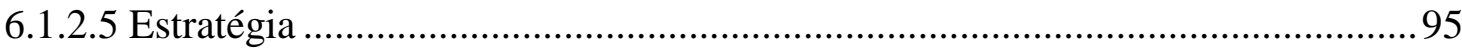

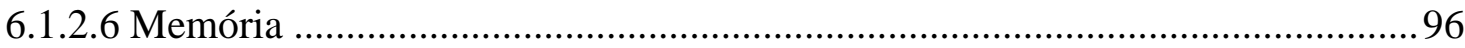

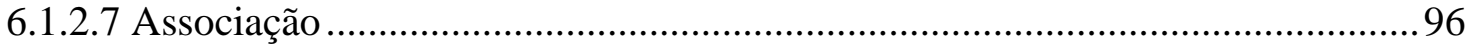

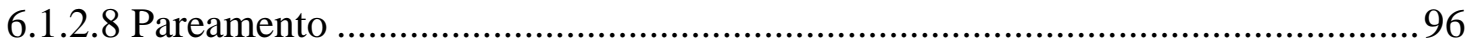

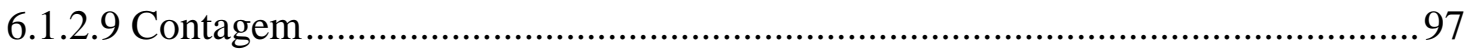

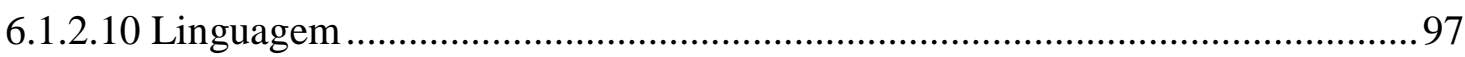

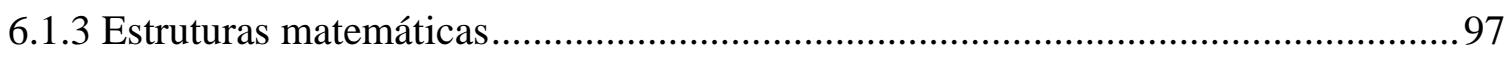

6.1.4 Habilidades desenvolvidas por cada jogo ........................................................ 100

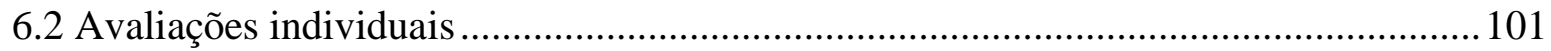

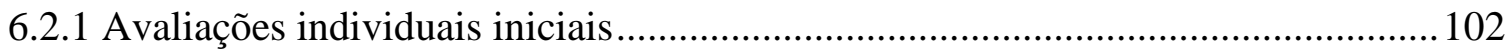

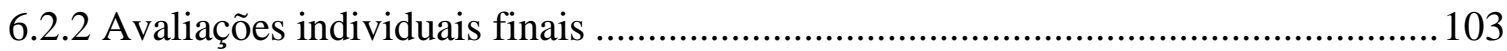

6.2.3 Dados comparativos das avaliações .................................................................. 104

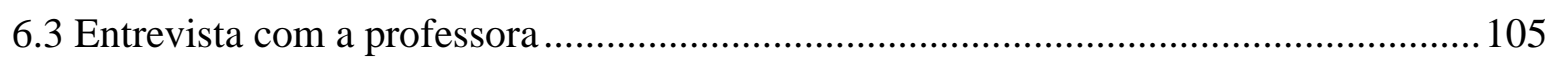

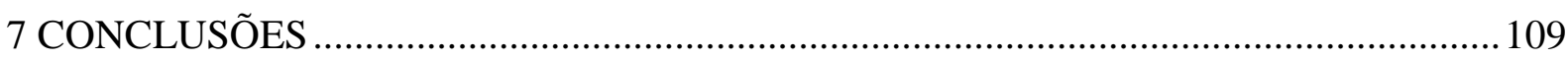

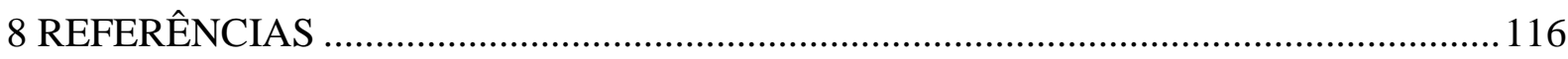

ANEXO A: QUADRO ORGANIZATIVO - LINGUAGEM MATEMÁTICA - CURRICULO EM MOVIMENTO DA EDUCAÇÃO BÁSICA (EDUCAÇÃO INFANTIL) .......................121 ANEXO B: AVALIAÇÃO DAS COMPETÊNCIAS E DIFICULDADES CONCEITUAIS

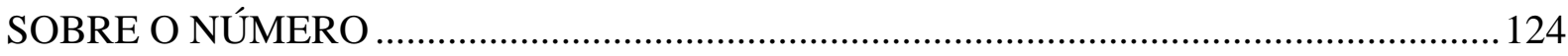

APÊNDICE A: PLANEJAMENTO DA PESQUISA (DIA A DIA) ................................... 126 
APÊNDICE B: TERMO DE CONSENTIMENTO LIVRE E ESCLARECIDO (TCLE)-

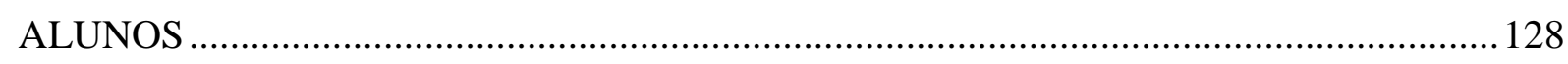
APENNDICE C: TERMO DE CONSENTIMENTO LIVRE E ESCLARECIDO (TCLE) -

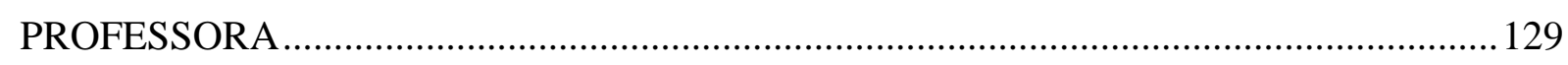

APÊNDICE D: TERMO DE AUTORIZAÇÃO PARA REALIZAÇÃO DA PESQUISA ... 130 APÊNDICE E: ROTEIRO DE ENTREVISTA COM A PROFESSORA .............................. 131

APÊNDICE F: CRONOGRAMA DE EXECUÇÃO DA PESQUISA (DIA A DIA) ............132 


\section{INTRODUÇÃO}

A escola é ambiente de grande desenvolvimento e crescimento, tanto pessoal quanto social. Este ambiente, onde o indivíduo passa grande parte de sua vida, deve estar preparado para promover a aprendizagem, apresentando estímulos adequados para cativar a criança. A busca pelo aprendizado deve ir além de uma obrigação ou imposição social. O indivíduo deve querer buscá-lo, deve desejá-lo. A escola, principal responsável pela promoção da aprendizagem, deve buscar meios de incitar no estudante o desejo de aprender, fazendo com que ele se sinta bem neste processo. Portanto, este processo não deve ser maçante, deve ser estimulante e lúdico.

O ambiente escolar deve ser acolhedor, interessante, provocativo e estimulante desde o início. Já na educação infantil os alunos devem ser provocados para o crescimento cognitivo, mas sem deixar de lado a essência da infância: a diversão e a espontaneidade.

$\mathrm{Na}$ fase de desenvolvimento da educação infantil as crianças estão em pleno crescimento cognitivo, mas muitas vezes não são estimuladas da maneira correta. É comum encontrar professores dessa etapa que não saibam como lidar com o desenvolvimento do conhecimento com alunos desta idade. Iniciam precocemente o processo de alfabetização da língua materna e deixam a matemática de lado, ou focam na aprendizagem do traçado e identificação de letras e números. Este não deveria ser o foco da educação infantil, mas sim formar as bases necessárias para a construção dos conhecimentos no decorrer da vida escolar e fora da escola.

Os professores apresentam resistência e dificuldade em especial com o trabalho com a aprendizagem matemática. Não sabem como conduzi-la, ou que instrumentos utilizar para estimulá-la, sendo que muitas vezes são utilizadas atividades maçantes e repetitivas, que não atraem as crianças.

Uma forma de estimular a aprendizagem matemática e o raciocínio dos alunos da educação infantil e despertar o seu interesse para a aprendizagem é utilizando instrumentos lúdicos, e em especial os jogos. O uso da ludicidade em sala desperta o prazer do aluno pelo aprendizado, fazendo com que ele busque este desenvolvimento de forma espontânea. A aprendizagem matemática é importante para o desenvolvimento escolar do aluno e pode ser promovida de forma lúdica. 
De acordo com Kamii (2012), interagir com o campo conceitual da matemática significa ser capaz de estabelecer relações e operações entre diferentes objetos, sejam eles de natureza concreta ou abstrata. Quando isto ocorre, "o pensamento se torna mais móvel” (p. 25), sendo o indivíduo capaz de analisar e assimilar conhecimentos com mais facilidade, bem como de desenvolver um pensamento autônomo e crítico. Deste modo, uma atividade para o ensino da matemática deve provocar este pensamento utilizando situações problemas, reflexão e raciocínio.

Segundo Saiz (1996), o conteúdo matemático deve ser significativo para o aluno. Para isto, a construção desta significação deve ocorrer tanto a nível externo quanto interno. A nível externo seria a compreensão de como este conteúdo poderia ser utilizado. Já a nível interno seria o entendimento do funcionamento do recurso.

Então, para compreender um conteúdo matemático, seria necessária a utilização de situações contextualizadas com a realidade das crianças e materiais concretos para sustentar a sua assimilação. A utilização do lúdico, por meio dos jogos, pode propiciar esta construção externa e interna dos contextos e estimular a aprendizagem significativa. Por meio do lúdico os alunos estabeleceriam uma aprendizagem significativa e uma relação prazerosa com a área de conhecimento da matemática.

Os jogos são uma excelente opção de instrumento para promover o desenvolvimento dos alunos de forma prazerosa, despertando o seu gosto pela escola e a aprendizagem. Mesmo na etapa da educação infantil não há necessidade de um jogo abordar um conteúdo específico para promover a aprendizagem. Os Jogos de Reflexão Pura oferecem diferentes situações e possibilidade que estimulam o pensamento e o raciocínio, auxiliado a aprendizagem matemática, além da interação entre os alunos. Estes jogos são capazes de estimular bases necessárias para a aprendizagem matemática da criança.

Desta forma, esta pesquisa busca levantar subsídios e materiais alternativos para o ensino da aprendizagem matemática na educação infantil. Para isso são utilizados Jogos de Reflexão Pura, acreditando que estes são capazes de promover a aprendizagem matemática de forma lúdica. 


\subsection{Historicidade do objeto de pesquisa}

O interesse em estudar o objeto aqui proposto foi construído ao longo de minha trajetória profissional e acadêmica.

Desde criança, as memórias que tenho da escola se relacionam os momentos prazerosos que vivi. As gincanas, passeios, brincadeiras, aulas na sala de informática, na biblioteca e as aulas com materiais concretos. Recordo-me do uso do material dourado e de instrumentos de medição, por exemplo.

Eu nunca tive dificuldade na escola e me destacava pelas boas notas com frequência. Em casa, eu não costumava sair para brincar na rua. Mesmo compreendendo a importância deste tipo de atividade, meus pais não permitiam que eu e meus irmão saíssemos do quintal por segurança. Assim, meus passatempos eram as bonecas, os desenhos animados e os jogos. Sempre tive contato com diferentes tipos de jogos, e me lembro de bons momentos com estes e toda a minha família.

Ao crescer, escolhi como profissão continuar na escola. Ingressei o curso de pedagogia em 2009 e no decorrer do curso tive contato com muitas matérias que apresentavam metodologias e instrumentos para o ensino das crianças. As matérias que mais me marcaram, que eu mais me interessei em estudar e aprender, foram aquelas em que eu me divertia, que instigavam a curiosidade, a criatividade e o prazer.

Percebi, então, a partir da minha vivência, a importância de atrair o aluno para o conhecimento de forma lúdica, e não o obrigar.

Iniciei a minha vida profissional em 2010 como auxiliar em uma escola que prezava pela ludicidade em sala. Tive cada vez mais certeza de que este elemento era essencial para uma educação de qualidade. Neste mesmo ano me matriculei no projeto "O Encanto no Aprender", me aprofundando na área da ludicidade. Prossegui com esse projeto por mais 4 semestres, até o final do curso de pedagogia, inclusive produzindo o meu trabalho de conclusão de curso sob este tema, com o título "A formação do sujeito autor: O lúdico como estratégia pedagógica potencializadora da autoria de pensamento".

Conclui o curso de pedagogia em 2011 e assumi uma turma como professora regente na cidade onde resido. Esta escola tinha uma metodologia mais tradicional e o foco era em tarefas escritas e na conclusão do livro didático. Não havia muita abertura para momentos lúdicos. Notei que a cobrança da escola e dos pais, que muitas vezes não compreendem a 
importância de uma brincadeira ou jogo, podem prejudicar o trabalho com a ludicidade. Não realizar todas as atividades do livro era considerado desperdício do investimento dos pais, e se as atividades adicionais fossem reduzidas a escola era vista como fraca.

Neste mesmo ano iniciei o curso de Psicopedagogia na Universidade de Brasília. Continuei com o estudo da ludicidade, utilizando jogos para o atendimento de crianças com dificuldade de aprendizagem.

Ao ingressar no quadro da Secretaria de Educação, em 2013, tive mais liberdade para conduzir a turma como julgava importante, pois não havia a mesma cobrança em concluir o livro didático ou preencher o caderno com fichas de atividades. Pude então introduzir na rotina escolar momentos de jogos e brincadeiras, livres e conduzidas. Trabalhei durante dois anos com o $5^{\circ}$ ano, e desenvolvi com as duas turmas um projeto com jogos e atividades de raciocínio lógico. Percebi que as atividades despertavam, além do interesse dos alunos pelas aulas, o desenvolvimento deles nas matérias que eu ministrava.

No ano seguinte fui para uma escola de educação infantil. Percebi que, apesar de as professoras buscarem manter um ambiente lúdico e disporem de muitos jogos em sala, elas não sabiam como utilizá-los com a turma ou qual era a sua importância para a aprendizagem dos alunos. Também foi possível observar que as professoras tinham dúvidas quanto ao ensino da matemática e que instrumentos poderiam utilizar nestas aulas.

Ao ter contato com os alunos, em especial os alunos do $2^{\circ}$ período, notei a capacidade que eles tinham para lidar com diferentes jogos que exigiam reflexão e estratégia. Tais jogos despertavam a atenção e o interesse dos alunos e podiam ser considerados uma forma de auxiliá-los na aprendizagem matemática. Na mesma época tive contato com o conceito de Jogos de Reflexão Pura, conhecendo sua capacidade de contribuir com a aprendizagem matemática, e busquei incorporar estes jogos à rotina da minha turma, trabalhando com os jogos sem focar em conteúdo.

A partir da observação das professoras e alunos da educação infantil e refletindo sobre o uso de jogos em sala de aula, surgiram as seguintes questões:

- Como trabalhar com Jogos de Reflexão Pura em sala de aula?

- De que modo Jogos de Reflexão Pura podem se constituir como uma ferramenta lúdica?

- Como o uso de Jogos de Reflexão Pura pode auxiliar a aprendizagem matemática?

- Quais são as estruturas matemáticas trabalhadas por meio dos Jogos de Reflexão Pura? 
Respondendo a estas questões seria possível verificar a influência dos Jogos de Reflexão Pura na aprendizagem matemática da faixa etária selecionada, contribuindo para a qualidade do ensino matemático na educação infantil.

\subsection{Pesquisas relacionadas}

Para tentar responder às questões que surgiram sobre a relação entre os Jogos de Reflexão Pura e a aprendizagem matemática na educação infantil, foi realizada uma busca entre as pesquisas recentemente desenvolvidas.

Esta busca foi realizada em dois momentos distintos: um antes de iniciar a pesquisa, entre os meses de novembro e dezembro de 2015 e outra após a conclusão da construção de dados e durante a análise das informações, nos meses de julho e agosto de 2016.

Na primeira pesquisa o objetivo era verificar se havia trabalhos que já respondessem as questões propostas. A segunda buscava ampliar a base de dados da primeira pesquisa, verificando, além da incidência de projetos similares, informações para enriquecer a análise dos dados coletados neste trabalho.

\subsubsection{Primeira pesquisa -2015}

Esta busca foi realizada nos dias 29 e 30 de novembro e 01 e 02 de dezembro do ano de 2015 e foram utilizadas as palavras "educação infantil", "jogo" ou "jogos" e "matemática", com o intuito de encontrar trabalhos que apresentassem todas ao mesmo tempo. Não houve restrição do lugar onde as palavras apareceriam, sendo que poderia ocorrer em todo o documento, no título, resumo, palavras-chave ou corpo do texto. Foi realizada uma busca por artigos, dissertações e teses brasileiros, sem estabelecer um recorte temporal, podendo ocorrer resultados de qualquer ano.

Foram utilizados como referência para o levantamento as seguintes bases de dados de acesso livre:

1. Repositório Institucional da Universidade de Brasília.

2. BDTD - Biblioteca Digital de Teses e Dissertações do Ibict - Instituto Brasileiro de Informação em Ciência e Tecnologia.

3. Scielo - Scientific Electronic Library Online. 


\section{EDUBASE.}

O estudo foi realizado a partir do site da Biblioteca Central da Universidade de Brasília, que disponibiliza acesso a diversas bases de dados. Dentre as opções, foram selecionadas aquelas com acesso livre e que apresentasse estudos brasileiros com referência à educação.

O Repositório Institucional da Universidade de Brasília, é vinculado à Universidade de Brasília, e dispõe de grande quantidade de teses e dissertações elaborado por alunos da referida instituição.

O BDTD, Biblioteca Digital Brasileira de Teses e Dissertações, foi lançado em 2002 é vinculado ao Ibict, Instituto Brasileiro de Informação em Ciência e Tecnologia. Reúne teses e dissertações de mais de 90 instituições de ensino e pesquisa brasileiras.

A Scielo, Scientific Electronic Library Online, é uma biblioteca eletrônica composta por uma grande quantidade de periódicos científicos. Foi fundada em 2002 e é parte de um projeto desenvolvido pela Fapesp - Fundação de Amparo à Pesquisa do Estado de São Paulo, em parceria com a Bireme - Centro Latino-Americano e do Caribe de Informação em Ciências da Saúde.

O Edubase é uma base de dados que apresenta artigos de periódicos nacionais em Educação e áreas afins. Foi fundado em setembro de 1994 pela Biblioteca da Faculdade de Educação da Unicamp, sendo a partir de abril de 2015, coordenada pelo Sistema de Bibliotecas da Unicamp.

A pesquisa inicial retornou 30 resultados. Destes, foram analisados os títulos e resumos, descartando textos que se referiam a outras etapas da educação e aqueles que tinham foco na educação inclusiva, sendo ao final selecionado 8 trabalhos que abrangiam os temas escolhidos. Os trabalhos selecionados foram analisados para verificar se havia relação com as perguntas propostas.

Desta forma, foram analisadas 8 produções relacionando matemática, educação infantil e jogos, sendo 2 artigos, 5 dissertações e 1 tese, todos produzidos entre os anos de 2004 e 2014, dispostos de acordo com o quadro a seguir. O foco desta segunda análise foram os objetivos propostos pelos trabalhos em questão, a metodologia utilizada e os resultados alcançados. 


\begin{tabular}{|c|c|c|c|c|}
\hline $\begin{array}{c}\text { BASE DE } \\
\text { DADOS }\end{array}$ & OCORRÊNCIAS & $\begin{array}{c}\text { OCORRENCIAS } \\
\text { RELEVANTES }\end{array}$ & ANO & TIPO \\
\hline $\begin{array}{c}\text { Repositório } \\
\text { Institucional } \\
\text { BCE/UnB }\end{array}$ & 19 & 1 & 2009 & Dissertação \\
\hline \multirow{2}{*}{ BDTD - Ibict } & 9 & 5 & 2004 & Dissertação \\
\cline { 3 - 5 } & 1 & & 2007 & Dissertação \\
\cline { 3 - 5 } & 1 & 1 & 2010 & Dissertação \\
\cline { 3 - 5 } & 1 & 1 & 2012 & Tese \\
\hline Edubase & 1 & & 2007 & Artigo \\
\hline Scielo & 1 & & Artigo \\
\hline
\end{tabular}

Quadro 1: Resultado da pesquisa bibliográfica realizada em 2015.

A dissertação intitulada Uma proposta de software de educação matemática para a educação infantil da autora Boscariol, produzida em 2004 pela Universidade Estadual de Campinas - Unicamp teve o objetivo de "desenvolver um software de educação matemática para educação infantil com a finalidade de propiciar a construção do número pela criança" (BOSCARIOL, 2004, p. 03). Assim, esta pesquisa propôs o uso de jogos para o ensino da matemática na referida fase da educação, porém, utilizava jogos eletrônicos, desenvolvidos com as crianças por meio do computador.

O artigo produzido por Grando e Nacarado no ano de 2007 e sob o título Educadoras da infância pesquisando e refletindo sobre a própria prática em matemática, reconhecia que a utilização de jogos era importante para o ensino da matemática na educação infantil. Porém, o foco deste estudo foi a atuação do professor, sendo a pesquisa realizada com um grupo de educadores, e não havendo contato com os alunos.

O estudo A resolução de problemas de estrutura aditiva por crianças da educação infantil: o uso de jogos e problemas escolares elaborado em 2007 pela autora Nascimento da Universidade de Pernambuco apresentou como objetivo "verificar o uso dos jogos na resolução de problemas da estrutura aditiva na educação infantil" (NASCIMENTO, 2007, p. 15). Nesta pesquisa foram utilizados jogos com regras como base para a criação e resolução problemas aditivos, analisando a melhor forma de trabalhar este conteúdo com a educação infantil. 
A dissertação de Silva, produzida em 2008 na Universidade de São Paulo, com o título Matemática na infância: uma construção, diferentes olhares, analisou a educação matemática a partir de um curso de formação para o professor da educação infantil e séries iniciais. A pesquisa teve como objeto o processo de aprendizagem do professor no referido curso, não analisando a aprendizagem do aluno.

$\mathrm{O}$ texto $O$ desenho como representação do pensamento matemático da criança no início do processo de alfabetização, escrito por Sandes no ano de 2009 na Universidade de Brasília, foi realizado com alunos do $1^{\circ}$ ano do ensino fundamental. Foram analisadas resoluções de situações problemas por meio de desenhos. Os jogos não eram objeto central do estudo, mas apareceram como um instrumento para propor problemas matemáticos.

Produzido em 2010 pela autora Rodrigues, a dissertação Matemática, educação infantil e jogos de linguagem: um estudo etnomatemático, propôs situações problemas aos alunos e observava os jogos de linguagem que se desenvolviam a partir deste, com o objetivo de "produzir novos olhares sobre a educação matemática no âmbito da educação infantil”" (RODRIGUES, 2010, p. 27).

A tese produzida em 2012 pela autora Azevedo vinculada à Universidade Federal de São Carlos e intitulada $O$ conhecimento matemático na educação infantil: o movimento de um grupo de professoras em processo de formação continuada serviu de base para a produção de um artigo, da mesma autora, no ano de 2014 com o título Narrativas de práticas pedagógicas de professoras que ensinam matemática na educação infantil. Este trabalho foi realizado com um grupo de estudos colaborativo de professores da educação infantil, analisando os conhecimentos metodológicos e matemáticos demonstrados por estes. Em tais discussões, os jogos apareciam como um meio possível de trabalhar a matemática nesta etapa.

Após a pesquisa e análise dos estudos selecionados, observou-se que há pouca produção relacionando os temas educação infantil, jogos e matemática. Dentre os estudos encontrados, também é possível notar a grande incidência de estudos com foco no professor, e não nos alunos.

Os jogos não aparecem em todas as pesquisas como objeto central, em algumas, são utilizados no desenvolvimento ou citados por educadores no resultado. Nenhuma das pesquisas foi realizada com base em Jogos de Reflexão Pura. 


\subsubsection{Segunda pesquisa -2016}

Ao final do primeiro semestre do ano de 2016, após concluir a construção de dados na escola, a pesquisa de produções foi realizada novamente. Tal pesquisa foi efetuada entre os dias 12 de julho e 2 de agosto de 2016 e teve como objetivo analisar se há ocorrências de novos trabalhos que respondam às questões propostas por esta dissertação e ampliar a bibliografia estudada sobre os temas escolhidos.

A pesquisa foi realizada nas bases de dados e seguindo os critérios explicitados no quadro abaixo.

\begin{tabular}{|c|c|}
\hline BASE DE DADOS & CRITÉRIOS \\
\hline Repositório Institucional - BCE/UnB & \multirow{4}{*}{$\begin{array}{l}\text { Busca de trabalhos publicados em } \\
\text { português no Brasil no ano de 2016, } \\
\text { utilizando como } \\
\text { "educação infantil", "matemática" e } \\
\text { "jogos". }\end{array}$} \\
\hline BDTD - Ibict & \\
\hline Scielo & \\
\hline Edubase & \\
\hline Anais do Enem & \multirow{2}{*}{$\begin{array}{l}\text { Comunicações científicas e palestras } \\
\text { publicadas nos últimos } 10 \text { anos, } \\
\text { utilizando como palavras-chave } \\
\text { "educação infantil" e "jogo". }\end{array}$} \\
\hline Anais do Sipem & \\
\hline Educação Matemática em Revista & $\begin{array}{l}\text { Ocorrências publicadas nos últimos } 10 \\
\text { anos, utilizando como palavras-chave } \\
\text { "educação infantil" e "jogo". }\end{array}$ \\
\hline
\end{tabular}

Quadro 2: Resultado da pesquisa bibliográfica realizada em 2016.

Esta pesquisa, bem como a anteriormente realizada, buscou por trabalhos que apresentassem como tema central a educação infantil, a matemática e os jogos. Tal busca ocorreu em duas etapas. Incialmente repetiu-se a busca nos bancos de dados já utilizados, verificando a inclusão de novos trabalhos no ano de 2016 e posteriormente foi feita uma nova busca em diferentes bases de dados

Os trabalhos publicados nas bases de dados do Repositório Institucional da Universidade de Brasília, da Biblioteca Digital de Teses e Dissertações do Ibict, da Scielo e 
do Edubase foram acessados a partir do site da BCE, Biblioteca Central do Estudante da Universidade de Brasília. O acesso às demais, os anais do Encontro Nacional de Educação Matemática, anais do Seminário Internacional de Pesquisa em Educação Matemática e da Educação Matemática em Revista, foi realizado por intermédio do site da Sociedade Brasileira de Educação Matemática, Sbem.

A pesquisa nos registros dos anais do Enem foi efetuada nos dias 12, 13, 19 e 29 de julho. Foram analisados os registros dos encontros realizados nos últimos 10 anos, entre os anos de 2007 e 2016, sendo analisados quatro encontros: o IX Enem, de 2007; o X Enem, de 2010; o XI Enem, de 2013 e o X Enem, de 2016. Nesta análise, buscou-se por ocorrências das palavras "jogo" e "educação infantil” nos títulos das palestras e comunicações científicas. Em nenhum dos encontros houveram palestras que continham no título as palavras propostas.

Com relação às comunicações científicas publicadas nos anais do Enem, como não era possível pesquisar mais de um termo ao mesmo tempo, foram realizadas duas pesquisas, uma com o termo "jogo" e outra com a expressão "educação infantil", analisando a partir dos títulos e resumos quais trabalhos abordavam os dois temas. Os resultados ocorreram segundo o quadro a seguir:

\begin{tabular}{|c|c|c|c|}
\hline Encontro & "Jogo" & $\begin{array}{c}\text { "Educação } \\
\text { Infantil" }\end{array}$ & $\begin{array}{c}\text { "Jogo" + "Educação } \\
\text { Infantil" }\end{array}$ \\
\hline IX Enem -2007 & 8 ocorrências & 5 ocorrências & Sem ocorrências \\
\hline X Enem -2010 & 8 ocorrências & 6 ocorrências & 3 ocorrências \\
\hline XI Enem - 2013 & 25 ocorrências & 8 ocorrências & 2 ocorrências \\
\hline XII Enem - 2016 & 30 ocorrências & 6 ocorrências & Sem ocorrências \\
\hline TOTAL & 71 ocorrências & 25 ocorrências & 5 ocorrências \\
\hline \multicolumn{2}{|c|}{ Quadro 3: Resultado da pesquisa em anais do Enem. }
\end{tabular}

Como exposto, apenas 5 comunicações científicas publicadas nos anais do Enem relacionam à educação infantil, aos jogos e à matemática.

Destas ocorrências, 3 trabalhos foram publicados no ano de 2010, sendo estes Pesquisa e produção de material de apoio regional aos docentes da Educação Infantil e séries iniciais, dos autores Pereira e Mafra; Um estudo de caso sobre a matemática na alfabetização em Jequié - BA escrito por Silva e Bortoloti; e Matematicando na Educação Infantil: a prática docente e a ludicidade no ensino da matemática, produzido por Melo, Brandão e Arruda. 
Os trabalhos encontrados na pesquisa do XI Enem, do ano de 2013 foram Educação Matemática na infância: práticas pedagógicas de um grupo de professoras da Educação Infantil, escrito por Azevedo e A educação infantil e o ensino de matemática: experiências piagetianas com crianças de cinco anos, produzido por Menestrina, Mandler e Leonardo.

A pesquisa aos anais do Sipem foi realizada nos dias 12, 13 e 19 de julho e 01 de agosto. Também se buscou pela ocorrência das palavras "jogo" e "educação infantil" nos títulos e palavras chaves das comunicações científicas publicadas. Assim como nos anais do Enem, houve a necessidade de duas pesquisas, uma com cada termo proposto.

De acordo com o proposto, foram selecionados os registros de três encontros: IV Sipem, V Sipem e VI Sipem, que ocorreram nos anos de 2009, 2012 e 2013 respectivamente. A pesquisa retornou o seguinte resultado:

\begin{tabular}{|c|c|c|c|}
\hline Encontro & "Jogo" & $\begin{array}{c}\text { "Educação } \\
\text { Infantil" }\end{array}$ & $\begin{array}{c}\text { "Jogo" + "Educação } \\
\text { Infantil" }\end{array}$ \\
\hline IV Sipem - 2009 & 2 ocorrências & 1 ocorrências & Sem ocorrências \\
\hline V Sipem - 2012 & 2 ocorrências & Sem ocorrências & Sem ocorrências \\
\hline VI Sipem - 2015 & 1 ocorrência & Sem ocorrências & Sem ocorrências \\
\hline TOTAL & 5 ocorrências & Sem ocorrências & Sem ocorrências \\
\hline \multicolumn{2}{r}{ Quadro 4: Resultado da pesquisa em anais do Sipem. } \\
\end{tabular}

Como relacionado acima, houveram poucas produções que continham os termos procurados, e nenhum trabalho relacionava ambos os termos.

Nos dias 29 de julho e 01 de agosto foi realizada a pesquisa na Educação Matemática em Revista. Assim como as demais, foram utilizados os termos "educação infantil", "jogo" e “jogos", sendo analisados os títulos e resumos verificado os trabalhos que abordavam todos os temas.

Ao pesquisar a expressão "educação infantil”, retornaram quatro resultados e com relação aos termos "jogo" e "jogos" apareceram nove trabalhos. Analisando os trabalhos encontrados, verificou-se que apenas três relacionavam os temas selecionados. O primeiro trabalho foi publicado na edição número 45 de agosto de 2015 sob o título A Importância dos Jogos na Perspectiva Histórico-Cultural para a Aprendizagem e Desenvolvimento da Criança na Educação Infantil e era de autoria de Carcanholo. As demais ocorrências foram publicadas em maio de 2016, na edição número 50 da revista, com os títulos de Educação Infantil e a Matemática na Alimentação Saudável, escrito por Carniel, Renken, Schneider e 
Fortunato; e Jogos Matemáticos e a Questão da Reciclagem: um Repensar Indispensável à Humanidade, produzido por Cani, Pereira, Moser e Scotini.

A pesquisa realizada nos sites Scielo, BDTD, Edubase e no Repositório da Biblioteca da Universidade de Brasília para verificar novas ocorrências se limitou ao ano de 2016 e retornou apenas um resultado. As pesquisas foram realizadas nas datas relacionadas no quadro abaixo.

\begin{tabular}{|c|c|}
\hline Base de dados & Data \\
\hline Scielo & 27 de julho \\
\hline Edubase & 27 de julho \\
\hline BCE/UnB & 01 de agosto \\
\hline BDTD & 02 de agosto \\
\hline
\end{tabular}

Quadro 5: Datas de realização das pesquisas.

O trabalho encontrado foi resultado da pesquisa dos sites BDTD e BCE/UnB, sendo uma dissertação produzida por Barroso pela Universidade de Brasília e é intitulado Jogos cooperativos na educação infantil e suas implicações para o espaço da sala de aula.

A pesquisa em novas bases de dados de trabalhos publicados nos últimos 10 anos em anais e revistas de educação matemática retornou 85 ocorrências com relação aos jogos e 29 publicações sobre a educação infantil. Apesar de este já ser um número reduzido, a quantidade de trabalhos que relacionam os dois temas foi ainda menor, apenas 8 produções.

Destes 8 trabalhos, analisando os títulos e resumos, ficou claro que três produções tinham foco na atuação do docente. Com relação aos demais cinco trabalhos, apenas um apresentava o jogo como foco principal, nos demais o jogo aparecia como resultado ou recurso utilizado.

Apenas a produção A Importância dos Jogos na Perspectiva Histórico-Cultural para a Aprendizagem e Desenvolvimento da Criança na Educação Infantil, publicada na Educação Matemática em Revista de autoria de Carcanholo (2015) apresentava o jogo e a educação infantil como focos centrais. Apesar de ter sido publicado em uma revista que aborda a educação matemática, este artigo não abordava a matemática como foco central. Esta pesquisa se tratava de um levantamento bibliográfico acerca dos jogos, seus usos e benefícios para as crianças da educação infantil, e não tinha contato direto com os alunos. Apesar de fazer um levantamento sobre os jogos, a pesquisa não fez referência aos Jogos de Reflexão Pura. 
Verificou-se também, através da atualização da pesquisa realizada anteriormente, que houveram poucas produções novas sobre o assunto. Apenas um resultado foi encontrado, a dissertação Jogos cooperativos na educação infantil e suas implicações para o espaço da sala de aula, da mestra Barroso (2016). Tal pesquisa trabalhava com a aplicação de jogos no $2^{\circ}$ período da educação infantil, o que se assemelha à proposta desta dissertação. Porém, a referida pesquisa utiliza os jogos cooperativos em seu desenvolvimento e não faz referência aos Jogos de Reflexão Pura.

A presente pesquisa reforça as conclusões da análise realizada no ano de 2015 , de que há pouca produção relacionando os temas educação infantil, jogos e matemática, sendo grande parte focado no trabalho docente. A nova busca também reafirma o fato de que poucas pesquisas apresentam o jogo como objeto central, e em nenhuma há referência aos Jogos de Reflexão Pura. Reforça-se também o fato de que não foram encontrados trabalhos semelhantes à dissertação aqui proposta, apesar de encontrar bibliografias que auxiliem a sua construção. 


\section{OBJETIVOS}

Com base nas questões levantadas, determinou-se como objeto deste estudo os Jogos de Reflexão Pura como ferramenta lúdica para a aprendizagem matemática. Seu objetivo geral é: Compreender os Jogos de Reflexão Pura na aprendizagem matemática na educação infantil.

Para responder as questões, foram propostos os seguintes objetivos específicos:

1. Elaborar método para aplicação dos Jogos de Reflexão Pura em uma sala de aula de educação infantil.

2. Analisar se o uso de Jogos de Reflexão Pura desperta o espírito lúdico dos alunos.

3. Verificar como o uso de Jogos de Reflexão Pura interfere na aprendizagem matemática.

4. Identificar as estruturas matemáticas estimuladas a partir dos Jogos de Reflexão Pura.

Buscando embasar o desenvolvimento da pesquisa aqui proposta, houve a necessidade de estudar os temas centrais de seu objeto: a ludicidade e a aprendizagem. 


\section{LUDICIDADE E APRENDIZAGEM}

O embasamento teórico é de fundamental importância para orientar as ações do desenvolvimento da pesquisa. É necessário conhecer profundamente os conceitos discutidos para que sejam bem desenvolvidos na prática. Os conceitos centrais que regem esta produção são a ludicidade e a aprendizagem, considerando seus desdobramentos e a relação existente entre ambas.

A ludicidade tem grande importância na aprendizagem. Sua presença no ambiente escolar torna o processo mais prazeroso e espontâneo, promovendo assim uma aprendizagem significativa. De acordo com Sommerhalder e Alves (2011), "um processo de ensinoaprendizagem embebido do espírito lúdico será muito mais significativo, portanto mais rico e fértil tanto para quem ensina quanto para quem aprende" (p. 55).

O mesmo autor evidencia que apesar de haver uma clara ligação entre a criança e a atividade lúdica, tornando inevitável a presença do jogo no ambiente escolar, este fato não é suficiente para promover tal relação sem que haja conflitos. Há nas escolas de educação infantil uma divisão entre o momento da brincadeira e de estudo, sendo o primeiro considerado recreação e o seguinte como o momento de promover a aprendizagem.

Desta forma, é importante abordar a essência e conceito da ludicidade, bem como seu papel na aprendizagem, focando especialmente no jogo e desenvolvendo o conceito de Jogo de Reflexão Pura. Em seguida, também será discutido o conceito de aprendizagem e sua relação com os jogos e a ludicidade.

\subsection{Ludicidade}

O conceito de ludicidade é usualmente associado aos jogos e brincadeiras, porém, apesar de serem formas de expressão do lúdico, não se restringe a estes. A ludicidade pode estar presente em qualquer objeto, atividade, momento ou relação. Porém, não é uma característica inerente ao objeto, sendo que mesmo um jogo ou brincadeira pode deixar de ser lúdico de acordo com o momento em que se insere. 
O lúdico é, então, um conceito subjetivo. Não se prende a um objeto, pessoa ou atividade, mas está na relação de cada indivíduo com estes elementos. De acordo com Macedo, Petty e Passos (2005, p. 18):

O espírito lúdico refere-se a uma relação da criança ou do adulto com uma tarefa, atividade ou pessoa pelo prazer funcional que despertam. A motivação é intrínseca; é desafiador fazer ou estar. Vale a pena repetir. O prazer funcional explica porque as atividades são realizadas não apenas como meio para outros fins (ler para obter informações, por exemplo), mas por si mesmas (ler pelo prazer de ler ou desafio de ler). O interesse que sustenta a relação é repetir algo pelo prazer da repetição.

Desta forma, a ludicidade pode estar presente em qualquer lugar, pois ela se relaciona ao sentimento provocado no indivíduo. A ludicidade desperta o prazer da atividade, e faz com que a pessoa deseje repeti-la. Este sentimento, o espírito lúdico, deve ser desenvolvido com relação ao estudo, à aprendizagem. É necessário despertar no aluno o prazer de aprender.

Como a ludicidade não se prende os elementos, mas sim à relação com estes, uma brincadeira ou jogo, mesmo sendo essencialmente lúdicos, podem não despertar este espírito lúdico no indivíduo. Também uma atividade pode ser lúdica para uma pessoa, mas não despertar a ludicidade para outra.

Negrine (2001) demonstrou concordar com o conceito de ludicidade aqui defendido quando relaciona o conceito de ludicidade ao de lazer, percebendo e destacando sua presença nos tempos livres. Assim, fica claro que o autor também percebe a ludicidade como algo prazeroso, espontâneo e subjetivo. O mesmo autor evidenciou que a ludicidade é indispensável à vida humana, pois promove a melhoria da qualidade de vida e cita que a atividade lúdica "deve ser pensada a partir de aspectos subjetivos, interiores, que retratem emoções, afetos, bem-estar" (p. 35).

Apesar de a ludicidade se relacionar com momentos livres e de prazer, esta deve ser encarada com a mesma seriedade de uma ciência, considerando a sua importância para o indivíduo. Negrine (2001) considerava que a ludicidade como ciência estaria fundamentada em quatro pilares de naturezas diferentes: sociológica, psicológica, pedagógica e epistemológica.

Sociológica porque atividade de cunho lúdico engloba demanda social e cultural. Psicológica porque se relaciona com os processos de desenvolvimento e de aprendizagem do ser humano em qualquer idade em que se encontre. Pedagógica porque se serve tanto da fundamentação teórica existente, como das experiências educativas provenientes da prática docente. Epistemológica porque tem fontes de conhecimentos científicos que sustentam o jogo como fator de desenvolvimento (NEGRINE, 2001, p. 42). 
Segundo o mesmo, considerar a ludicidade como ciência seria não apenas oferecer oportunidades de momentos lúdicos, mas sim explorar as atividades propostas de forma que se possa extrair deste tempo evidencias para analisar como cada um reage a este momento, podendo assim perceber o que desperta o espirito lúdico para cada indivíduo.

Percebendo a ludicidade como algo inerente ao indivíduo e como um momento de lazer e prazer, onde a atividade é encarada de forma espontânea, bem como sua importância para o desenvolvimento humano em diferentes níveis, fica clara a necessidade de as instituições de ensino incorporarem este conceito a suas rotinas, e trabalharem buscando desenvolver o espirito lúdico.

No ambiente escolar, a ludicidade deve estar presente. O professor deve despertar este espírito lúdico no aluno, tornando a aprendizagem prazerosa, desenvolvendo no aluno o desejo pelo conhecimento para que ele e o busque de forma espontânea. Quando o aluno descobrir o prazer de aprender ele não necessitará de auxílio externo para buscar ampliar seus conhecimentos.

Assim, a escola deve acolher a cultura lúdica infantil e, para isso, deve não apenas apresentar as atividades aos seus alunos, mas compartilhar com a criança suas brincadeiras, seus jogos, conhecer as histórias que eles carregam e instigar a sua curiosidade, buscando seduzir o aluno ao conhecimento e ao conhecimento de si mesmo (SOMMERHALDER e ALVES, 2011).

Neste contexto, é tarefa do professor não apenas apresentar as atividades lúdicas, mas determinar as estratégias de intervenção nestas. As intervenções propostas devem ser planejadas para promover aprendizagens significativas, "uma vez que não tem sentido pensar o lúdico pelo lúdico, já que não existe ação sem uma intenção, mesmo quando esta escapa à percepção imediata daquele que a realiza" (NEGRINE, 2001, p. 40).

Para Negrine (2001), era claro o valor da atividade lúdica para a aprendizagem uma vez que esta era capaz de favorecer a aproximação das pessoas na realização das atividades, promover uma melhor compreensão entre estas pessoas e promover o crescimento individual resultando em um desenvolvimento de todo o grupo.

É importante também considerar que, apesar de a ludicidade ser natural para o indivíduo, em especial na infância, a criança não nasce sabendo brincar. É necessário promover sua interação com o brinquedo, com o jogo e com outras pessoas para que possa desenvolver esta habilidade. A criança deve ter contato com brinquedos e jogos, além de 
possibilidade de explorá-los, bem como oportunidade de observar outras crianças jogando e interagir com elas podendo assim descobrir como brincar e jogar e aprender novos jogos e brincadeiras. A intervenção do professor também é importante neste momento, pois este pode ensinar novas atividades aos seus alunos e promover tal interação (SOMMERHALDER e ALVES, 2011).

Assim, percebe-se que o comportamento lúdico é um comportamento adquirido a partir das influencias do meio, e é produto de uma cultura lúdica. Negrine (2001) acreditava que o comportamento lúdico sempre se relaciona a alguma atividade, individual ou coletiva, sendo é necessário tempo para este desenvolvimento.

Desta forma, para o desenvolvimento de uma cultura lúdica em sala, possibilitando que os alunos apresentem um espírito lúdico, é importante promover momentos de contanto com materiais lúdicos. A ludicidade pode ser expressa de diversas formas, porém, alguns objetos auxiliam este processo. Kishimoto (2000) destacava dois tipos de materiais lúdicos: os jogos e os brinquedos.

O brinquedo se relaciona ao brincar, que é uma atividade mais livre, que, mesmo contendo regras pré-estabelecidas, são regras flexíveis. O formato do brincar, da brincadeira e a utilidade do brinquedo são definidos pelo indivíduo e podem ser modificados ao longo da atividade.

O jogo, diferente do brincar, é uma atividade com estrutura fixa, onde há regras que devem ser seguidas até o final. O jogo necessita desta estrutura para acontecer. As regras são definidas antes da atividade e não há possibilidade de modificá-las, a não ser que seja de comum acordo entre todos os jogadores.

Para a presente pesquisa, serão utilizados como instrumentos de expressão lúdica os jogos, buscando desenvolver com o auxílio destes o espírito lúdico dos alunos.

\subsubsection{Jogos: instrumentos de expressão lúdica}

O jogo é um instrumento que possibilita o desenvolvimento do espírito lúdico, e é um aliado do professor em sala, pois, além de ter o poder de divertir os alunos, este desenvolve a aprendizagem. Utilizando jogos em sala de aula o professor poderá tornar lúdica a sua aula e a aprendizagem de seus alunos. 
A educação infantil é uma importante fase da infância, sendo que neste espaço os jogos estão presentes de forma mais natural. Assim, é a etapa ideal para aproveitar esta atividade como ferramenta de trabalho pedagógico, possibilitando que as crianças brinquem e aprendam, enquanto vivenciam a ludicidade (BARROSO, 2016).

Segundo Huizinga (2007) o jogo é um fenômeno cultural. Este motiva o indivíduo a utilizar a inteligência, cria um clima de liberdade que estimula o interesse e a descoberta, possibilita a autodescoberta, integração e a autoestima. Para Kishimoto (2000), o jogo pode ser usado como mediação para auxiliar crianças com dificuldade de aprendizagem a se tornarem sujeitos pensantes e participantes.

Piaget (apud CHIAROTTINO, 2010) colocava que o jogo é um meio poderoso para a aprendizagem, pois favorece o intercâmbio entre pensamento e a realidade, estimula a troca de ideias, a colocação de hipóteses, a experimentação e o teste da realidade, contribuindo no desenvolvimento cognitivo do aluno. Para Muniz (2010) o jogo possibilita à criança manifestar os seus sentimentos e seu pensar, explorar seu meio físico, social e cultural, se comunicar e manter uma relação entre o real e o imaginário.

O jogo deve ser livre e voluntário, a pessoa tem que querer para jogar, deve gostar de jogar. Ele expressa uma fuga da vida real, não se constituindo como realidade, mas sim fantasia. Esta distinção entre jogo e realidade ocorre pelo tempo espaço que ocupa, sendo que o jogo é limitado temporariamente e fisicamente. Esta atividade é composta também de tensão e regras, o que o torna capaz de absorver totalmente o jogador. O jogo é capaz ainda de formar grupos sociais, havendo, por exemplo, grupos formados por jogadores de determinado jogo (HUIZINGA, 2007).

Caillois (apud MUNIZ, 2010) colocava que o jogo pode ser realizado a partir de perspectivas psicológicas, sociológicas, filosóficas, históricas, pedagógicas e matemáticas. Este autor também propõe elementos necessários para que uma atividade seja considerada um jogo. São eles: ser livre, improdutiva, regrada, simuladora da realidade e ter tempo e espaço próprios. Com relação às pesquisas de Caillois e Brougère, Muniz elencou outros elementos necessários ao jogo: regras, jogadores, base simbólica e enfrentamento de riscos.

Piaget (1990) também estabeleceu critérios para classificar o jogo. Segundo este autor, o jogo apresenta três critérios:

1. Encontra sua finalidade em si mesmo.

2. É espontâneo 
3. É uma atividade pelo prazer, não tem um resultado útil.

Assim, o autor aproxima o sentido de jogo do conceito de ludicidade proposto anteriormente, considerando que o jogo é uma atividade espontânea, que desperta o prazer funcional, fazendo com que a finalidade da atividade se encerre em si mesma. É importante destacar que, o fato de o autor considerar que o jogo não tem resultado útil não significa que esta seja uma atividade "inútil”" em todos os níveis. Ela não tem resultado útil prático, não produz recursos. Mas o jogo tem um resultado útil quando se considera o desenvolvimento do indivíduo que joga.

O autor também destaca que, apesar de o jogo ser considerado por muitos como desinteressado, de certa forma em algum momento todo jogo é altamente interessado, uma vez que, enquanto o jogador está inserido neste, tem grande interesse em seu resultado, em finalizar a atividade com a vitória.

O jogo é também promotor e formador de cultura. Ele produz a cultura e é modificado por esta. Kishimoto (2000) citou que o jogo tem sentidos e significados diferentes em cada sociedade, sendo que uma mesma atividade pode ser considerada jogo ou não dependendo da atribuição dada em cada cultura.

Brougère (2014) demonstrava concordar com a citação acima, quando dizia que o jogo é um produto cultural, sendo que seu conceito é relativo de acordo com a cultura em que se insere. O jogo se insere em uma cultura que o valida. Segundo este:

a presença de uma cultura preexistente que define o jogo, torna-o possível e faz dele, mesmo em suas formas solitárias, uma atividade cultural que supõe a aquisição de estruturas que a criança vai assimilar de maneira mais ou menos personalizada para cada nova atividade lúdica (p. 22/23).

O autor definia a cultura lúdica como o conjunto das regras e significados do jogo que cada jogador cria e adquire no contexto da atividade. Esta é indispensável para tornar o jogo possível e se diversifica de acordo com a cultura em que está inserida, adequando-se ao meio social, cidade, sexo e idade da criança. A cultura lúdica é produzida pelos indivíduos que dela participam.

Em sala de aula, o jogo é um poderoso aliado do professor. Para Barroso (2016), esta atividade pode ser um meio privilegiado de educação, pois:

no jogar, as crianças compreendem regras, vivenciam situações que se repetem, assimilam conhecimentos sobre si e sobre os outros. Dentro de um jogo, há infinitas possibilidades de se resolver um problema, permitindo que os participantes formulem e reformulem hipóteses. Nessa prática, eles se tornam mais livres. Ainda por cima, jogando com os outros, os seres humanos reforçam a convivência e aprimoram as relações interpessoais que representa (p. 37). 
Brenelli (2008), também destacava que o jogo pode ser utilizado para auxiliar alunos com dificuldades na aprendizagem, pois sua exploração sistemática "desencadearia o processo de equilibração responsável pela estruturação cognitiva" (p. 17). Tal fato ocorre, pois, a situação problema proposta pelo jogo se constitui como um desafio que o jogador quer vencer, o que provoca uma perturbação, sendo que de sua compensação procede o desenvolvimento do pensamento. Segundo o referido autor, é esta dificuldade e desafio que precisam ser superados que atrai a criança para o jogo. Este interesse que as crianças apresentam com relação aos jogos pode se configurar como uma oportunidade de realizar operações aritméticas, e para a aprendizagem destas noções em um contexto lúdico (BRENELLI, 2008).

Em um ambiente escolar o jogo demonstra sua importância pois, apesar de muitas vezes ser utilizado apenas como atividade de recreação, este desenvolve no indivíduo "suas percepções, sua inteligência, suas experimentações, seus instintos sociais" (BRENELLI, 2008, p. 21). O jogo contribui, assim, para o processo de assimilação.

De acordo com Piaget (1990), por meio do jogo o aluno é capaz de assimilar e interpretar o mundo a sua volta e a si mesmo. Desta forma, o jogo tem um alto valor educacional, pois contribui com o processo de aprendizagem.

Segundo Miranda (2014), o jogo mobiliza dimensões humanas. Ele desenvolve a cognição, a socialização, a afetividade, a motivação, a criatividade e a psicomotricidade. Há jogos que mobilizam mais uma dimensão do que a outra, mas um mesmo jogo pode mobilizar diferentes dimensões ao mesmo tempo. Não há como dissociar uma da outra. Mesmo que a atividade tenha sido elaborada com foco em uma dimensão específica, ela promoverá em segundo plano o desenvolvimento das demais.

Para a presente pesquisa serão utilizados os jogos que tem como foco principal a mobilização da dimensão cognitiva. Segundo o autor acima citado, este tipo de jogo possibilita o exercício da conscientização, resolução de problemas, elaboração do pensamento lógico, abstração, linguagem, percepção e processos criativos.

Miranda (2014, p. 41) destacava que:

na pratica do jogo infantil, faz-se importante a valorização do aspecto cognitivo que está sendo trabalhado, mas é indispensável que o prazer e a alegria sejam os eixos da atividade. $\mathrm{O}$ aspecto cognitivo deve aliar-se efetivamente ao aspecto afetivo. 
Há diferentes tipos de jogos que mobilizam a dimensão cognitiva. Jogos educativos, jogos de estratégias e desafios, entre outros. No desenvolvimento desta pesquisa serão utilizados aqueles classificados como Jogos de Reflexão Pura.

\subsubsection{Jogos de Reflexão Pura}

Quando se imagina um jogo para ser utilizado em ambiente escolar, espera-se que este trabalhe um conteúdo específico visando sua introdução ou fixação com os alunos de maneira lúdica. Porém, há estruturas que também devem ser estimuladas e desenvolvidas na escola e que não se relacionam diretamente aos conteúdos, mas que podem auxiliar em sua posterior compreensão.

Tendo em vista o trabalho com a educação infantil, onde os alunos começam a ter contato com as diferentes matérias, é importante ter acesso a instrumentos que possibilitem ao professor estimular a aprendizagem das crianças, mas sem foco em um conteúdo específico.

Desta forma, para a presente pesquisa, escolheu-se como instrumento para trabalhar com os alunos os Jogos de Reflexão Pura. Por meio deste tipo de jogo, serão trabalhadas estruturas matemáticas com os alunos, sem a necessidade de introduzir um conteúdo, o que poderá facilitar a sua compreensão da matemática.

A definição de Jogos de Reflexão Pura foi desenvolvida a partir da interpretação de estudos de Spada (2009), Mezzaroba (2009) e Muniz (2010).

Os Jogos de Reflexão Pura foram selecionados por se relacionarem com a matemática de uma forma livre, sem se prenderem aos conteúdos. Estes jogos propõem problemas e situações que estimulam a reflexão do jogador, o que mobiliza as estruturas matemáticas.

Este tipo de jogo pode ser classificado, de acordo com Spada (2009), como jogo matemático, de modo que suas regras se confundem com as regras formais da matemática. É, segundo a mesma autora, uma atividade voltada à recreação.

Segundo Muniz (2010), os Jogos de Reflexão Pura foram criados sobre estruturas lógico matemáticas e, por causa desta relação, são considerados altamente criativos. Porém, apesar de se relacionar com a matemática, tais jogos não apresentam um conteúdo específico. Estes se relacionam aos processos de matematização, promovendo estruturas necessárias à aprendizagem matemática. Assim, mesmo não apresentando um vínculo concreto com um 
conteúdo matemático, se relaciona por meio de competências transversais à aprendizagem matemática.

Este tipo de jogo pode ser trabalhado com diferentes faixas etárias, e suas bases permanecem similares, não havendo distinção entre o jogo proposto para o adulto e para a criança. Assim, no decorrer da atividade são exigidas as mesmas estruturas matemáticas de qualquer participante. $\mathrm{O}$ jogo do adulto e da criança são distintos apenas por sua complexidade, mas proporcionam o mesmo desenvolvimento (MEZZAROBA, 2009; MUNIZ, 2010).

De acordo com os estudos dos autores referidos, os Jogo de Reflexão Pura podem ser considerados jogos de competição, pois promovem a competição entre dois competidores. Este tipo de jogo é classificado como Agôn de acordo com a proposição de Caillois (1967)

Há diferentes formas de classificar os tipos de jogos existentes. Em seu trabalho, Caillois (1967) estabelecia quatro grupos principais para tal classificação e os denominam de Agôn, Alea, Mimicry e Ilinx. A categoria Agôn se refere a todo tipo de jogo que se apresenta sob forma de competição, tanto de "caráter muscular" quanto de "tipo mais cerebral" (p. 34). Os Alea são jogos que contam com o fator sorte, ou jogos de azar. A categoria Mimicry se refere àqueles de simulações e imitações infantis, bem como teatro e artes do espetáculo em geral. Nesta categoria se encaixam os jogos de faz-de-conta. A última categoria, o Ilinx, se refere a jogos que produzem a sensação de vertigem, como balanço e carrossel.

Os Jogos de Reflexão Pura proporcionam a concorrência entre duas pessoas ou equipes, o que promove o prazer pela competição. A competição é importante para manter o participante interessado, mesmo que se apresente uma dificuldade a ser vencida. Tal fator também amplia a interação entre os jogadores, e contribui para que o jogo seja sempre desafiador, pois a cada movimento do adversário o jogo muda, necessitando de nova estratégia.

O objetivo dos jogos propostos é a resolução de um problema matemático, o que deve ser validado pelos demais jogadores, ou seja, a resposta ao problema deve ser aceita por todos os participantes para ser válida. Neste tipo de jogo, o aspecto do azar é excluído, sendo que a reflexão e desenvolvimento de estratégias são importantes para vencer o jogo. É necessário que o participante compreenda suas regras e o problema proposto para resolução e crie estratégias para vencer o seu adversário. 
Como o jogador não pode contar com a sorte para vencer, dependendo assim da sua tática, o Jogo de Reflexão Pura pode ser considerado como jogo de estratégia. Para Cunha e Nascimento (2005) este tipo de jogo estimula a vida social e a atividade construtiva da criança. É essencial que ela esteja atenta, pois sua vitória dependerá da eficácia das estratégias desenvolvidas e da forma como ela planeja e executa tal estratégia.

De acordo com Piaget (1990), há três classes de jogo: exercício, símbolo e regra. Estas correspondem às três fases da inteligência: sensório motora, representativa e refletida. Os jogos de exercício diminuem com o surgimento da linguagem e os de regras iniciam de 4 a 7 anos e seu desenvolvimento dura por toda vida.

Nesta classificação proposta por Piaget (1990) os Jogos de Reflexão Pura se adequam aos jogos de regras, carregando suas características e benefícios.

Os jogos de regras se sobrepõem aos jogos simbólicos. A regra, neste contexto, se pauta nas relações sociais ou interindividuais. É uma regularidade imposta pelo grupo, sendo que infringir esta representa uma falta. Algumas das regras acompanham formalmente o jogo e são transmitidas de jogador para jogador, porém há outras regras que são criadas pelos jogadores. As primeiras são chamadas de regras transmitidas, as posteriores são as regras espontâneas.

Mesmo as regras espontâneas têm sua importância e base nas regras já conhecidas. “O indivíduo só se impõe regras por analogia com as que recebeu. Nunca comprovamos a existência de regras espontâneas numa criança isolada" (PIAGET, 1990, p. 182).

Os jogos de regras podem ser compostos dos mesmos elementos dos demais jogos, mas apresentam como característica principal a regra. Assim, os jogos de regras são

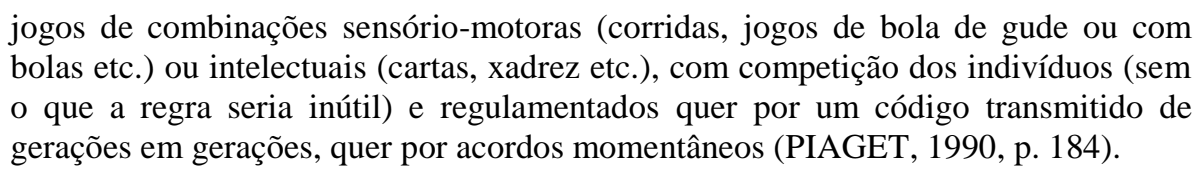

Em resumo, a partir das leituras, deduz-se que para que uma atividade seja considerada um jogo de reflexão pura, deve atender aos seguintes quesitos:

1. Desenvolver estruturas matemáticas;

2. Não apresentar conteúdos específicos;

3. Promover a competição entre dois jogadores ou duas equipes;

4. Não apresentar o aspecto do azar. 
Com base nos autores estudados, estes jogos favorecem o desenvolvimento do raciocínio abstrato e lógico, o que auxiliará na aprendizagem matemática. Além disto, carrega as características dos jogos de competição e de estratégia. Por ser um jogo de competição, também possibilita ao jogador lidar com a perda, com a frustração

Como jogo de estratégia, de acordo com Cunha e Nascimento (2005), mobilizam e desenvolvem a atenção e a concentração, além de favorecer a organização e domínio das relações de espaço e tempo, pois o jogador deve planejar o que fazer a cada momento, aguardando o tempo certo da jogada.

Assim, a partir dos estudos realizados, compreende-se que os Jogos de Reflexão Pura são um tipo de jogos de estratégia construídos sobre bases matemáticas, mas que não apresentam um conteúdo matemático específico. Estes promovem a competição entre dois adversários e seu desenvolvimento não conta com o fator sorte, de modo que o planejamento do jogador é essencial para vencê-lo. Estes jogos desenvolvem habilidades que contribuem com a aprendizagem matemática.

\subsection{Aprendizagem}

Em um ambiente escolar, sempre há a busca por meios para proporcionar a aprendizagem. Este é um tema amplamente debatido na literatura acadêmica e apresenta diferentes opiniões, classificações e definições desenvolvidas.

Moreira (1999) expôs a existência de três tipos de aprendizagem: a cognitiva, a afetiva e a psicomotora. A cognitiva ocorre a partir do armazenamento de informações na mente de quem aprende. A aprendizagem afetiva é proporcionada pelos sentimentos do indivíduo, como por exemplo a dor, o prazer e a ansiedade. Por fim, a psicomotora é relacionada às respostas musculares proporcionadas pela prática. Os três tipos estão relacionados entre si, sendo que a aprendizagem cognitiva e a afetiva estão ligadas, e para que ocorra a aprendizagem psicomotora há necessidade de desenvolvimento cognitivo. A relação entre as dimensões da aprendizagem é recíproca.

Assim, as atividades escolares que visam promover a aprendizagem devem buscar incluir as três dimensões. Os recursos lúdicos podem conseguir este objetivo, visto que trabalham o armazenamento de informações a partir de atividades prazerosas e da interação com o meio, estimulando respostas musculares. 
Muitos autores buscaram definir o termo "aprendizagem" em seus trabalhos. Moreira coloca que o termo aprendizagem é usualmente definido como "modificação do comportamento resultante de experiência" (1999, p. 102). Porém, há teóricos que não concordam com tal definição, como é o caso de Piaget, que, segundo o mesmo autor, acreditava que esta definição estabelecia que o sujeito dependia do ambiente para aprender. Piaget preferia definir aprendizagem como o "aumento do conhecimento" (apud MOREIRA, 1999, p.102).

Para Piaget a aprendizagem podia ser considerada como "um resultado adquirido em função de uma experiência" (1974, p. 52), porém, o autor ressaltava a complexidade desta definição dizendo que nem todo resultado adquirido constitui uma aprendizagem. Isso porque há conclusões ou pensamentos que são instantâneos e não configuram uma real mudança no indivíduo a longo prazo. Assim, para ser considerada uma aprendizagem, a mudança proporcionada deve ser duradoura.

Tal mudança geralmente não ocorre de forma instantânea, mas sim é construída, desenvolvida. Nas palavras de Piaget, "é necessário pois reservar o termo de aprendizagem a uma aquisição em função da experiência, mas se desenvolvendo no tempo, quer dizer mediata e não imediata como a percepção ou a compreensão espontânea" (1974, p. 53). É importante ressaltar que há a possibilidade de aquisições resultante não de experiências, mas de um processo dedutivo que também configuram aprendizagem, o que pode ocorrer a partir dos 7 anos de idade.

O referido autor também destacava mais uma questão com relação à aprendizagem. Segundo este, há aquisições mediatas "obtidas em função de uma indução propriamente dita" (1974, p. 53), ou seja, o treino para a reprodução de um conhecimento. Este tipo de aquisição não deve ser classificado como uma aprendizagem.

Assim, percebe-se que a aprendizagem não pode ser definida pela forma como foi construída, mas sim pela modificação que causa no indivíduo. As aquisições do indivíduo devem provocar uma modificação duradoura e significativa para ser considerado aprendizagem.

Neste sentido, Piaget (1974, 2015; MOREIRA, 1999) desenvolveu sua teoria sobre o processo de aprendizagem baseado em duas etapas: a assimilação e a acomodação.

Assimilação é definida como a "incorporação dos objetos aos esquemas das ações do sujeito de tal forma que um objeto é percebido e concebido em função das ações que o 
utilizam" (PIAGET, 1974, p. 59). Essa incorporação ocorre quando o sujeito tem contato com o objeto, através da observação ou interação com este.

Assim, o indivíduo constrói esquemas mentais de assimilação para abordar a realidade. Todo conhecimento precisa ser assimilado, atribuir significados incorporando objetos aos esquemas mentais. Quando os esquemas já formados não são capazes de assimilar determinada informação há necessidade de modificação do organismo. Ocorre, então, o processo de acomodação, que proporciona desenvolvimento cognitivo. "Se o meio não apresenta problemas, dificuldades, a atividade da mente é, apenas, de assimilação, porém, diante deles, ela se reestrutura (acomodação) e se desenvolve” (MOREIRA, 1999, p. 100).

Em resumo, o indivíduo conhece novos elementos, objetos ou informações que se ligam a conhecimentos já esquematizados em sua mente, causando uma modificação nos esquemas construídos. Essa modificação é a segunda etapa do processo de aprendizagem, denominada acomodação.

A acomodação consiste na capacidade de modificação da estrutura mental antiga para dar conta de dominar um novo objeto do conhecimento. De acordo com Piaget (1974), este processo comporta dois aspectos que se relacionam.

Em primeiro lugar, ele designa uma atividade: apesar da modificação do esquema de
assimilação ser imposta pelas resistências do objeto, ela não é dilatada pelo objeto,
mas pela reação do sujeito tendendo a compensar essa resistência (ela pode dessa
forma proceder por reação imediata, ou por tentativas e erros, etc.), Mas, em
segundo lugar, se a acomodação ainda é uma atividade, consistindo em diferenciar
um esquema de assimilação, ela é somente derivada ou secundária com relação à
assimilação (p. 65).

Desta forma, não é correto dizer que todo esquema tende a se acomodar a qualquer objeto. O fato é que ele busca assimilar todo objeto, mas pode não ser capaz de assimilá-lo por conta de resistências exteriores. Tal objeto não se aplica ou se diferencia dos esquemas já produzidos, não provocando a acomodação. Nestes casos a criança tende a buscar vencer estes obstáculos, encarando-os como desafios. "Assistiremos, pois à formação de condutas de exploração ou a "experiências para ver" que poderíamos ser tentados a interpretar como o resultado de uma tendência à acomodação como tal” (PIAGET, 1974, p. 65).

Quando o esquema é capaz de assimilar e acomodar o objeto ou conhecimento, ocorre a equilibração. Esta etapa é caracterizada pelo equilíbrio entre o processo de assimilação e acomodação, ocasionando a adaptação à situação, o que dá origem a novos esquemas mentais.

Para Piaget (2015), o equilíbrio apresenta três características. Primeiro este se distingue por sua estabilidade. Porém, não se deve considerar a estabilidade como 
imobilidade. Assim, o equilíbrio apesar de ser estável ele é também móvel. Sua segunda característica é que pode sofrer estímulos externos, sendo que tais estímulos tendem a modificar o equilíbrio, não sendo este fixo. Por fim, o equilíbrio não pode ser considerado com passivo, pois apresenta "alguma coisa de essencialmente ativo" (PIAGET, 2015, p. 133).

Desta forma, pode-se perceber que mesmo um esquema que tenha sofrido assimilação e acomodação, alcançando assim a equilibração, não é um sistema concluído, ele está em constante movimento e desenvolvimento.

De acordo com Piaget, a aprendizagem e o desenvolvimento ocorrem juntos, sendo que um depende do outro. Em seus estudos, o autor diferenciava o desenvolvimento do indivíduo do desenvolvimento da aprendizagem, acreditando que o corpo se desenvolve de maneira espontânea, mas a aprendizagem é desenvolvida por "um agente externo interessado em promover a aquisição de algum ponto didático" (GOMES E BELLINI, 2009). O autor também explicitava a necessidade de interagir com o meio e com o objeto para gerar o conhecimento, citando que para formular o conhecimento é necessária ação sobre o meio.

Fernandez (2001) também apresentou a sua contribuição em relação à aprendizagem. Para a autora ensinar e aprender estão relacionados. Segundo ela:

Entre o ensinante e o aprendente abre-se um campo de diferenças onde se situa o prazer de aprender. $\mathrm{O}$ ensinante entrega algo, mas para poder apropriar-se daquilo o aprendente necessita inventá-lo de novo. É uma experiência de alegria, que facilita ou perturba, conforme se posiciona o ensinante. (FERNANDEZ, 2001, p. 29).

É função do ensinante provocar no aprendente o prazer pelo aprender e deixá-lo explorar e descobrir seu aprendizado. É necessário também que o sujeito tenha vontade de aprender, e que o ensinante queira que este aprenda.

A aprendizagem deve ser um processo global, envolvendo as esferas cognitiva, afetiva e psicomotora, fruto de interação social e de ação sobre o meio. Para tal, há a necessidade de um ambiente estimulante, que possibilite ao indivíduo explorar e interagir de forma espontânea, e que vá além da aquisição de conteúdos para um fim específico.

Para que esta ocorra é necessário, além da maturação dos esquemas biológicos, o contexto social, pois neste processo são essenciais a interação e a ação sobre o meio. A aprendizagem deve ser simplificada e significativa, já que não há como apressá-la, mas sim como motivá-la, tornando-a prazerosa e recompensadora por si própria. 
Partindo do estudo da aprendizagem e considerando que o objetivo deste trabalho é a aprendizagem matemática, há a necessidade de aprofundar o tema, discutindo suas bases e desenvolvimento.

\subsubsection{Aprendizagem matemática}

Antes mesmo de a criança ser inserida ao convívio escolar ela já tem acesso a uma grande quantidade de informação no ambiente em que vive. Neste ambiente ela está em contato diariamente com instrumentos que utilizam e reproduzem a linguagem matemática. Deste modo, quando a criança chega à escola, mesmo nos primeiros anos de escolarização, ela já tem uma bagagem de conhecimentos matemáticos construída.

Por meio de músicas, de programas de televisão, jogos e brincadeiras a criança aprende a recitar os números, além disso, é estimulada pela família a contar e pode observar as pessoas a sua volta utilizando a contagem e operações matemáticas a todo o momento. Assim, quando ingressa a escola, ou antes mesmo de iniciar a vida escolar, algumas crianças já se mostram capazes de reproduzir este conhecimento, recitando, por exemplo, corretamente uma sequência numérica com números pequenos. Porém, isso não demonstra que estas crianças compreendem realmente o que significam as palavras que estão repetindo em série ou qual é a sua função.

Quando chegam à escola, o ambiente escolar e as rotinas pedagógicas estimulam a criança a reproduzir este conhecimento, mas este aluno não apresenta as estruturas básicas necessárias para o desenvolvimento matemático.

É, então, importante tornar o aluno numerizado. Isto significa ser capaz de refletir matematicamente sobre todo tipo de situações. Para que isso seja possível é preciso:

\footnotetext{
conhecer os sistemas matemáticos de representação que utilizaremos como ferramentas. Estes sistemas devem ter sentido, ou seja, devem estar relacionados às situações nas quais podem ser usados. E precisamos ser capazes de entender a lógica destas situações, as invariáveis, para que possamos escolher as formas apropriadas de matemática. (NUNES e BRYANT, 1997, p. 31).
}

O desenvolvimento do conceito de número é, segundo a teoria de Piaget (1979; NUNES e BRYANT, 1997; KAMII, 2012), a base para a aprendizagem matemática. Segundo Kamii (2012, p. 18), “o número é a relação criada mentalmente por cada indivíduo”, sendo que ele não pode ser ensinado para o aluno, que tem que construí-lo sozinho. 
A mesma autora ainda coloca que não há uma clareza de como a criança faz esta construção, apesar de haver evidencias teóricas de que a concepção do número ocorre dentro de um contexto mais geral, envolvendo todo tipo de informação fornecida pelo ambiente em que o indivíduo está inserido. A noção de número surge a partir das relações que o indivíduo faz sobre todos os tipos de coisas. Piaget (1979) diz que as primeiras operações da criança em desenvolvimento são decorridas das suas ações sobre os objetos. Estas operações "derivam das coordenações sensório-motoras, cujas ações instrumentais, na criancinha já comportam seguramente "estruturas"” (PIAGET, 1979, p. 24).

De acordo com Piaget (1979; NUNES e BRYANT, 1997; KAMII, 2012) para que o indivíduo se desenvolva matematicamente é necessário aprender algumas estruturas lógicomatemáticas.

As estruturas lógico-matemáticas não são ensinadas e nem percebidas pelas crianças e não podem ser transmitidas a ela pela família ou escola. Estas estruturas devem ser desenvolvidas pela criança, e este desenvolvimento só pode ocorrer se ela possuir instrumentos de assimilação, ou seja, ela precisa de um amadurecimento cognitivo para assimilá-las (PIAGET, 1979).

Apesar de as estruturas logico-matemáticas serem uma construção do aluno, elas não são concebidas livremente, ou seja, a criança não as constrói da maneira que quer. Tais estruturas têm especificidades que devem ser compreendidas, sendo que o desenvolvimento desta construção demanda muito tempo, pois há a necessidade de obedecer suas leis particulares,

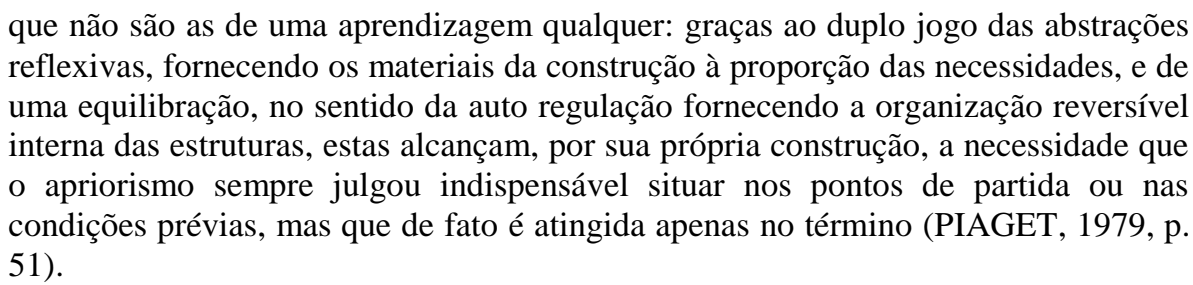

De acordo com Piaget (2015), as estruturas lógico-matemáticas surgem a partir das ações, sendo produto da abstração das ações realizadas sobre os objetos, não sendo assim estimuladas apenas pelos objetos. Porém, é importante colocar que estas estruturas não são simplesmente a interiorização das ações.

A partir de teorias do conhecimento, a psicologia da inteligência elenca três fatores que contribuem para a formação destas estruturas. Estes são a maturação, a experiência e a transmissão social. O primeiro fator, a maturação, é um componente interno e hereditário, e 
seria o desenvolvimento do organismo físico. A experiência seria a relação com o meio físico, onde entraria as ações acima citadas. Por fim, a transmissão social, que se característica pela relação com o outro. $\mathrm{O}$ conjunto destes três fatores promove o desenvolvimento das estruturas lógico-matemáticas, sendo que cada um tem a sua importância neste processo, mas nenhuma é suficiente por si só (PIAGET, 2015).

Outro ponto importante levantado por Piaget (2015) é que a construção destas estruturas lógico-matemáticas ocorre na fase infantil, mas estas "fazem parte de todas as formas evoluídas do pensamento adulto" (p. 73).

Para a aquisição dessas estruturas, desenvolvendo assim a aprendizagem matemática, as crianças devem obedecer a alguns princípios lógicos (PIAGET, 1979; NUNES e BRYANT, 1997; KAMII, 2012).

Um desses princípios é a natureza ordinal do número, isso significa não apenas lembrar-se da sequência dos números, mas "entender que esta ordem obedece à regra que se 3 é mais do que 2 e 2 é maior do que 1" (NUNES e BRYANT, 1997, p. 20), então 3 será maior do que 1. Também é preciso compreender que não importa a ordem na qual os objetos são contados, o número final será o mesmo.

O principal princípio lógico-matemático proposto por Piaget (NUNES e BRYANT, 1997; KAMII, 2012) foi a conservação. Para os autores, compreender conservação significa saber que o número de um conjunto de objetos apenas poderá ser alterado por operações matemáticas, tais como adição e subtração. Deste modo, as outras mudanças, como alterações nos elementos e arranjo espacial, serão irrelevantes.

A compreensão da conservação também permite que as crianças tenham noção de cardinalidade do número, pois se elas acreditam que um conjunto de objetos tem sua quantidade alterada por meio do arranjo espacial ela não saberá que um conjunto com determinada quantidade de objetos é o mesmo em número que qualquer outro conjunto com a mesma quantidade. Por exemplo, um grupo de seis laranjas tem a mesma quantidade que um grupo com seis bonecas. Segundo Nunes e Bryant (1997), se as crianças não compreendem a conservação, não poderão saber o que fazem quando estão contando, e ao contar estarão apenas repetindo as palavras que nomeiam os números.

De acordo com os autores referidos, outra regra lógica básica é a da transitividade. A transitividade seria a compreensão de que se um número A, é maior do que outro, B, sendo B 
maior $\mathrm{C}$, então o número A deve, obrigatoriamente, ser maior do que C. A apreensão desta regra lógica básica é essencial para a compreensão do conceito de número.

O aluno que não compreende estas regras lógicas, não compreende o conceito de número e não é capaz de assimilar a lógica da adição e da subtração. Assim, a criança poderá até ser capaz de realizar operações simples com facilidade, mas não compreenderá o que está fazendo. Para que o indivíduo alcance essa compreensão é necessário que percebam as relações entre adição e subtração e a concepção de número, sendo que apenas estas ações podem modificá-lo (NUNES e BRYANT, 1997).

Lorenzato (2011), também estudava o desenvolvimento da matemática na educação infantil. Este autor elencou processos mentais que considera como bases para a matemática, evidenciando não conteúdos, mas sim estruturas que o aluno precisa desenvolver para apoiar o aprendizado matemático. Segundo o autor, sua proposta "visa ao desenvolvimento integral da criança, como não poderia deixar de ser, mas possui propositalmente um componente direcionado à futura aprendizagem da matemática” (LORENZATO, 2011, p. 23).

Foram propostos por ele sete processos mentais: correspondência, comparação, classificação, sequenciação, seriação, inclusão e conservação. Percebe-se que alguns dos elementos propostos se assemelha aos estudos de Piaget.

O primeiro processo explorado por Lorenzato (2011) foi a correspondência. Esta foi definida como a capacidade de estabelecer a relação "um a um". Em seguida, o autor conceituou a comparação como sendo o ato de estabelecer diferenças ou semelhanças entre objetos selecionados. O terceiro processo, a classificação, podia ser considerada como a ação de separar elementos em categorias de acordo com suas semelhanças ou diferenças. A sequenciação, quarto elemento listado, "é o ato de fazer suceder a cada elemento um outro sem considerar a ordem entre eles" (2011, p. 26). Em seguida, era exposto o conceito de seriação como sendo a ordenação de uma sequência de acordo com um critério estabelecido. A inclusão também foi listada como o "ato de fazer abranger um conjunto por outro" (2011, p. 27). Por fim, a conservação era definida como a capacidade de perceber que a quantidade independe da organização, formato ou posição.

O desenvolvimento destes processos é de grande importância, pois se não forem trabalhados com os alunos, eles podem apresentar dificuldade ao aprender o conceito de número e contagem, além de outras operações e conceitos matemáticos. "Sem o domínio desses processos, as crianças poderão até dar respostas corretas, segundo a expectativa e a 
lógica dos adultos, mas, certamente, sem significado ou compreensão para elas" (LORENZATO, 2011, p. 25).

A partir dos estudos realizados, acredita-se que, apesar de não utilizar diretamente os números, os Jogos de Reflexão Pura podem auxiliar no desenvolvimento do conceito de número na educação infantil, além de trabalhar processos mentais básicos que influenciarão na aprendizagem matemática.

Conjuntamente aos elementos já citados, espera-se que com o uso de Jogos de Reflexão Pura seja possível desenvolver o pensamento lógico, a reflexão, a atenção, a discriminação visual, a estratégia, a memória, a associação, o pareamento, a contagem e a linguagem, entre outras habilidades relacionadas à matemática. Estes elementos foram elencados tendo como base os estudos de Cunha e Nascimento (2005) e as habilidades desenvolvidas por meio de jogos matemáticos, jogos de competição, jogos de estratégias e jogos de regras, categorias em que se encaixa a definição proposta de Jogos de Reflexão Pura.

Trabalhando estas habilidades poderá ser possível estimular o pensamento dos alunos, auxiliando-os a fazer relações entre objetos e resolver situações problemas.

Para o projeto de pesquisa aqui proposto, os elementos acima citados serão compreendidos da seguinte forma:

- Pensamento lógico: Conclusão a partir dos fatos.

- Reflexão: Pensar sobre algo.

- Atenção: Focar uma atividade ou instrumento.

- Discriminação visual: Perceber detalhes de uma imagem, diferenciar coisas, encontrar padrões e alterações nos padrões.

- Estratégia: Plano para vencer um obstáculo/problema/desafio.

- Memória: Armazenamento de informações.

- Associação: Estabelecer uma ligação entre elementos de acordo com suas semelhanças.

- Pareamento: Formação de pares seguindo critérios ou para um objetivo proposto.

- Contagem: Uso dos números para quantificar quantidades.

- Linguagem: Comunicação e expressão oral.

Os alunos sujeitos desta pesquisa estão, de acordo com Piaget (2015), em uma fase de construção do pensamento lógico. O autor coloca que entre as idades de 2 a 7 anos há um período de transição entre formas de pensamento. 
A primeira destas formas é a do pensamento por incorporação ou assimilação puras, cujo egocentrismo exclui, por consequência, toda objetividade. A segunda destas formas é a do pensamento adaptado aos outros e ao real, que prepara, assim, o pensamento lógico (PIAGET, 2015, p. 20).

É assim, pois, importante promover a mobilização do pensamento lógico, o que pode ser proporcionado pelos Jogos de Reflexão Pura.

Além destas habilidades, após uma análise do quadro organizativo do currículo em movimento da educação infantil (ANEXO A), percebe-se conteúdos estipulados para serem trabalhados com alunos do $2^{\circ}$ período que podem ser desenvolvidos por meio dos jogos propostos por esta pesquisa.

O quadro organizativo de linguagem matemática é divido em quatro subgrupos: números e operações, grandezas e medidas, espaço e forma e tratamento da informação. Cada subgrupo contém os conteúdos a serem trabalhados em cada etapa da educação infantil. Diversos conteúdos podem ser trabalhados por meio dos jogos. Além dos jogos, a competição entre os alunos e a contagem de pontos também estimulam a matemática em sala. Estas atividades auxiliam no desenvolvimento dos conteúdos relacionados a seguir, entre outros.

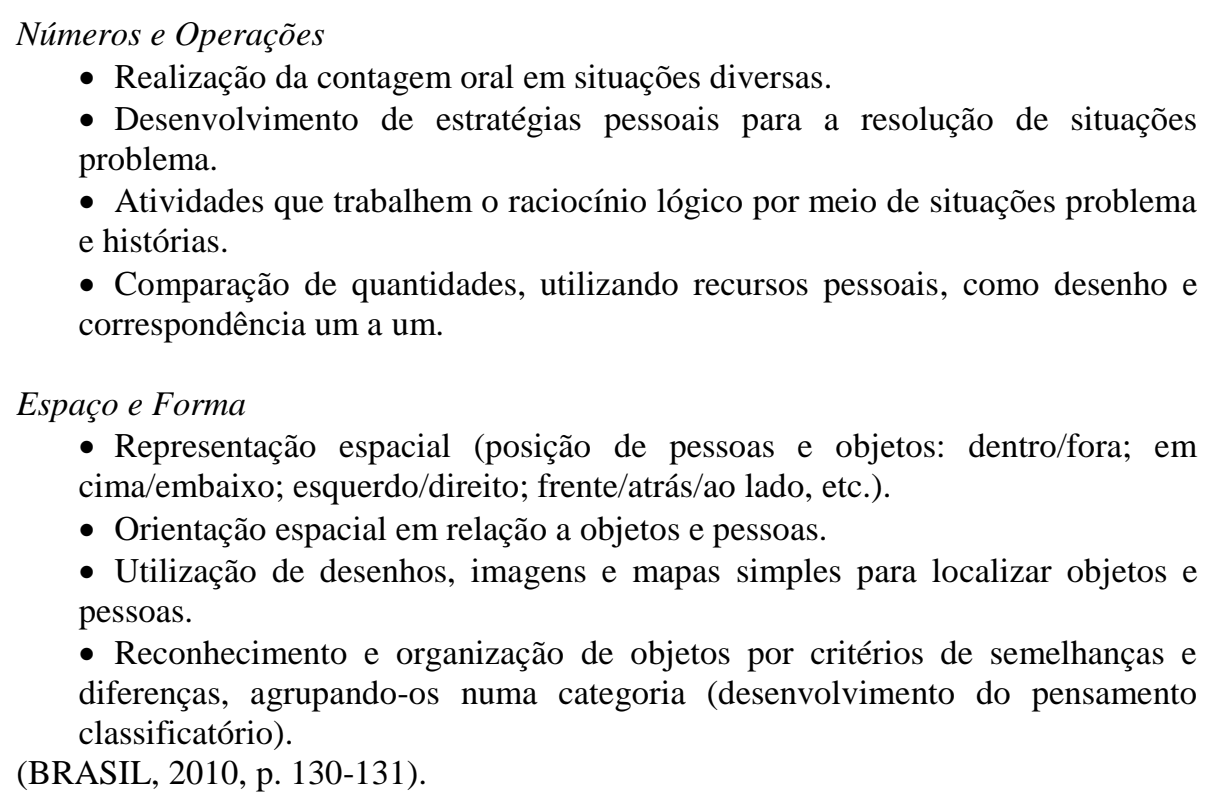

Acredita-se, então, que os conceitos e estruturas matemáticas básicas da educação infantil podem ser desenvolvidos a partir do uso de Jogos de Reflexão Pura, auxiliando a aprendizagem dos alunos de forma lúdica e significativa. 


\section{PROCEDIMENTOS METODOLÓGICOS}

\subsection{Descrição da pesquisa}

Esta pesquisa foi proposta com o objetivo de investigar a relação lúdica entre os Jogos de Reflexão Pura e a aprendizagem matemática com alunos do $2^{\circ}$ período da educação infantil. Para tal, foi observada e analisada a aplicação de jogos como ferramenta lúdica, com foco na relação dos alunos com eles e sua influência na aprendizagem matemática.

O planejamento e desenvolvimento da referida pesquisa seguiu o estabelecido no quadro de coerência abaixo:

OBJETO: Jogos de Reflexão Pura como ferramenta lúdica para a aprendizagem matemática.

OBJETIVO GERAL: Compreender os Jogos de Reflexão Pura na aprendizagem matemática da educação infantil.

\begin{tabular}{|c|c|c|}
\hline $\begin{array}{l}\text { QUESTÕES DE } \\
\text { PESQUISA }\end{array}$ & $\begin{array}{l}\text { OBJETIVOS } \\
\text { ESPECÍFICOS }\end{array}$ & $\begin{array}{l}\text { PROCEDIMENTOS/ } \\
\text { INSTRUMENTOS }\end{array}$ \\
\hline $\begin{array}{l}\text { Como trabalhar com } \\
\text { Jogos de Reflexão Pura } \\
\text { em sala de aula? }\end{array}$ & $\begin{array}{c}\text { Elaborar método para } \\
\text { aplicação dos Jogos de } \\
\text { Reflexão Pura em uma sala } \\
\text { de aula de educação infantil. }\end{array}$ & $\begin{array}{l}\text { - Aplicação de diferentes Jogos de } \\
\text { Reflexão Pura para uma turma do } \\
2^{\circ} \text { período da educação infantil. } \\
\text { - Registro em um diário de campo } \\
\text { escrito e em áudio e vídeo. }\end{array}$ \\
\hline $\begin{array}{l}\text { De que modo Jogos de } \\
\text { Reflexão Pura podem se } \\
\text { constituir como uma } \\
\text { ferramenta lúdica? }\end{array}$ & $\begin{array}{l}\text { Analisar se o uso de Jogos } \\
\text { de Reflexão Pura desperta o } \\
\text { espírito lúdico dos alunos. }\end{array}$ & $\begin{array}{l}\text { - Observação participativa da } \\
\text { interação dos alunos com os jogos } \\
\text { propostos. } \\
\text { - Conversa informal com os alunos } \\
\text { sobre os jogos propostos. } \\
\text { - Registro em um diário de campo } \\
\text { escrito e em áudio e vídeo. }\end{array}$ \\
\hline
\end{tabular}




\begin{tabular}{|c|c|c|}
\hline $\begin{array}{l}\text { Como o uso de Jogos de } \\
\text { Reflexão Pura pode } \\
\text { auxiliar a aprendizagem } \\
\text { matemática? }\end{array}$ & $\begin{array}{c}\text { Verificar como o uso de } \\
\text { Jogos de Reflexão Pura } \\
\text { interfere na aprendizagem } \\
\text { matemática. }\end{array}$ & $\begin{array}{l}\text { - Avaliação inicial e final dos } \\
\text { alunos utilizando recursos lúdicos. } \\
\text { - Debate com as crianças sobre as } \\
\text { aprendizagens proporcionadas por } \\
\text { estes. } \\
\text { - Entrevista semiestruturada com a } \\
\text { professora da turma. } \\
\text { - Registro em um diário de campo } \\
\text { escrito e em áudio. }\end{array}$ \\
\hline $\begin{array}{l}\text { Quais são as estruturas } \\
\text { matemáticas trabalhadas } \\
\text { por meio dos Jogos de } \\
\text { Reflexão Pura? }\end{array}$ & $\begin{array}{c}\text { Identificar as estruturas } \\
\text { matemáticas estimuladas a } \\
\text { partir dos Jogos de Reflexão } \\
\text { Pura. }\end{array}$ & $\begin{array}{c}\text { - Análise das regras iniciais dos } \\
\text { jogos e das escolhidas pelos } \\
\text { participantes. }\end{array}$ \\
\hline
\end{tabular}

Quadro 6: Quadro de coerência da pesquisa.

\subsection{Metodologia}

Como a pesquisa se baseou no trabalho com um grupo de alunos, lidando diretamente com eles e observando suas concepções e seu desenvolvimento, se enquadra na abordagem qualitativa. Esta abordagem se refere à aquisição dos dados por meio do contato do pesquisador com a realidade estudada, sendo que é dada mais importância ao processo do que ao produto (LÜDKE; ANDRÉ, 1986).

Segundo Bortoni-Ricardo (2008) o paradigma qualitativo tem sua origem no interpretativismo e surgiu como uma alternativa ao modelo de pesquisa quantitativo. A pesquisa quantitativa tem por objetivo estabelecer relações de causa e consequência, já a qualitativa busca analisar e compreender os fenômenos sociais dentro de um contexto. Com base no paradigma interpretativo o mundo não pode ser observado ignorando as práticas sociais e os significados presentes no observador. Para a autora a pesquisa qualitativa tem, em sala de aula, o dever de "construir e aperfeiçoar teorias sobre a organização social e cognitiva da vida em sala de aula, que é o contexto por excelência para a aprendizagem dos educandos" (BORTONI-RICARDO, 2008, p. 42).

De acordo com a mesma autora, a pesquisa qualitativa aceita o fato de que o pesquisador é parte do mundo, portanto não há como produzir uma pesquisa totalmente 
objetiva, este "não é um relator passivo, mas sim um agente ativo na construção do mundo" (BORTONI-RICARDO, 2008, p. 59).

Assim, a pesquisa foi realizada a partir da ação do pesquisador e provocando reflexão também sobre seu trabalho, não apenas sobre as ações dos sujeitos. Desta forma, apresenta características da metodologia da Pesquisa-Ação. Segundo Barbier (2007, p. 21) a pesquisaação é a "ciência da práxis exercida pelos técnicos no âmago do seu local de investimento". O mesmo autor cita que a pesquisa-ação tem o objetivo de servir de instrumento de mudança social. O processo de pesquisa deve então levar o pesquisador e os sujeitos a uma reflexão tal que consiga provocar mudança em sua prática. A pesquisa-ação está, deste modo, mais interessada no conhecimento prático do que no conhecimento teórico.

A pesquisa-ação exige a interação do pesquisador com a realidade estudada e seu envolvimento com os processos da pesquisa (BARBIER, 2007; GIL, 2009, 2011).

Para a presente pesquisa foi considerado o método da pesquisa-ação inspirado em Lewin. Tal método é o da espiral com suas fases: de planejamento, de ação, de observação e de reflexão, depois de um novo planejamento da experiência em curso. O rigor da pesquisaação repousa na coerência lógica empírica e política das interpretações propostas nos diferentes momentos da ação. "Nada de pesquisa sem ação, nada de ação sem pesquisa, como dizia Lewin. A abordagem em espiral supõe igualmente que, mesmo se nós nunca nos banhamos duas vezes no mesmo rio, segundo a fórmula heraclitiana, ocorre-nos olhar duas vezes o mesmo objeto sob ângulos diferentes" (BARBIER, 2007, p. 117). Assim, cada sessão realizada com os alunos foi analisada e serviu de base para o planejamento da sessão seguinte, pois, assim como já mencionado, o jogo que não despertasse o interesse do aluno seria substituído.

Para a construção dos dados e produção de informação da pesquisa foram selecionados como instrumentos a observação, a entrevista e a análise das atividades desenvolvidas.

A observação é importante em uma pesquisa qualitativa por proporcionar a interação do pesquisador com o fenômeno pesquisado, sendo esta a melhor maneira de verificar a ocorrência ou não de um fenômeno e de se aproximar da perspectiva dos indivíduos observados. Segundo Vieira (2009), este é o método em que o pesquisador se torna participante no grupo que estuda. A observação também permite a construção de dados que não podem ser coletados por outros instrumentos de pesquisa (LÜDKE; ANDRÉ, 1986). 
Todas as sessões com os alunos deveriam ser registradas em áudio para apoiar a análise do pesquisador, bem como em um diário de bordo. Barbier (2007) recomendava que o pesquisador ande sempre com um instrumento para anotações. Segundo o autor, este diário deve ser elaborado em três fases. Inicialmente um rascunho, realizado no momento da observação. Tal rascunho deverá ser revisto e será desenvolvido um diário elaborado, incluindo as informações importantes que devem ser transmitidas aos outros. Por fim, deve ser organizado um diário comentado.

O material coletado por meio das entrevistas, observação e atividades produzidas pelos alunos, bem como a teoria estudada servirão de apoio para a elaboração de um esquema de interpretação dos fenômenos estudados. Essa intepretação estará apoiada em três aspectos: nos resultados conseguidos por meio da pesquisa, na fundamentação teórica e na experiência pessoal do investigador (TRIVINOS, 1987).

\subsection{Etapas da pesquisa}

O planejamento inicial da pesquisa propõe duas etapas principais: a avaliação individual dos alunos e a aplicação dos jogos.

Cada jogo seria disponibilizado por um período de 5 aulas. Sempre que um novo jogo fosse apresentado, ele estaria inserido em uma "caixa surpresa" para que os alunos imaginassem o que poderia ser, instigando a curiosidade e o desejo de interação. No primeiro encontro seriam apresentadas as regras do jogo, utilizando um exemplar em tamanho grande. Neste momento, todos os alunos da turma estariam sentados "em rodinha". Nos encontros posteriores os alunos formariam grupos de 4 a 6 alunos para jogar, sempre em número par para poderem se dividir em duas equipes. As crianças receberiam o material em tamanho reduzido e seriam observadas pela pesquisadora enquanto jogassem. A pesquisadora deveria analisar a reação dos alunos à atividade proposta, sendo que as informações construídas guiariam o desenvolvimento da oficina posterior. Se um jogo não despertasse o interesse dos alunos ele seria substituído antes do termino das 5 aulas, buscando assim manter o aspecto lúdico da pesquisa.

Antes de iniciar a aplicação dos jogos os alunos seriam avaliados individualmente, observando seu desenvolvimento com relação à aprendizagem matemática. A avaliação seria realizada utilizando recursos lúdicos e baseada no currículo estabelecido pela Secretaria de 
Educação para o $2^{\circ}$ período da Educação Infantil. Esta avaliação deveria ser repetida ao final da pesquisa de campo para posterior comparação. Os alunos também seriam avaliados a cada jogo, por meio das observações diárias e questionamentos.

A avaliação individual ocorreria antes e depois da aplicação de jogos. Juntamente com a avaliação final, seria realizada uma entrevista com a professora para conhecer e analisar suas impressões sobre o projeto e percepções acerca do desenvolvimento dos alunos, buscando complementar o olhar da pesquisadora sobre os alunos. Estas etapas deveriam ocorrer conforme estabelecido nas descrições a seguir.

\subsubsection{Avaliação individual do aluno}

Durante o desenvolvimento do projeto os alunos seriam avaliados diariamente ao lidar com os jogos propostos. Neste momento seriam realizadas observações, questionamentos e interferências. Apesar da riqueza e importância da avaliação ao longo do processo, percebe-se a necessidade de um momento individual com cada aluno. Neste momento, poderiam ser verificadas as habilidades que cada aluno apresenta inicialmente e ao final da pesquisa, podendo assim concluir se houve desenvolvimento nos aspectos analisados.

É importante ressaltar que os instrumentos de avaliação inicial e final funcionariam apenas como complemento da avaliação diária. Portanto deveriam ser considerados juntamente com as observações e avaliações do processo, compondo, assim, uma análise mais completa do desenvolvimento e aprendizagem dos alunos.

A avaliação individual dos alunos foi baseada em conceitos e estruturas matemáticas que se espera desenvolver com os jogos e que são esperados para uma turma de segundo período da educação infantil.

Com o uso dos jogos, esperava-se desenvolver estruturas básicas para a formação do conceito de número e conceitos estabelecidos pelo currículo em movimento da educação infantil, bem como estruturas matemáticas básicas.

Cada aluno seria avaliado antes do início do desenvolvimento dos jogos e após finalizar esta atividade, sendo utilizados três instrumentos para a avaliação inicial e reutilizados na avaliação ao final. As ferramentas escolhidas foram:

- Um trecho da avaliação das competências e dificuldades conceituais sobre número, elaborada pelo grupo CIMETE (ANEXO B). 
- Um quebra-cabeças ou desafio para os alunos resolverem.

- Um jogo para localizar imagens escondidas.

Foram selecionados jogos e brinquedos para a avaliação buscando manter o aspecto lúdico da pesquisa. É importante destacar que a pesquisadora estaria em contato com os alunos antes do início das avaliações, pois acompanharia a turma durante a semana de adaptação, criando um vínculo com os alunos. As avaliações seriam registradas em vídeo.

Para avaliar o desenvolvimento de estruturas para a formação do conceito de número, foram selecionados os itens 1,2 e 3 da avaliação das competências e dificuldades conceituais sobre número (FÁVERO, 2012). Este instrumento foi selecionado por ser bem-conceituado e fundamentado, tendo sido utilizado em diversas pesquisas. Além disto, utiliza ferramentas relacionadas à infância e que chamam a atenção das crianças, que são as miniaturas de animais de pelúcia. Este instrumento busca "avaliar as competências e dificuldades conceituais sobre a noção de número através de pequenas quantidades numéricas, sem recurso à escrita e à memorização" (FÁVERO, 2012, p. 2). Foram selecionados apenas os três primeiros itens por estarem mais adequados à idade dos participantes da pesquisa.

O material produzido para a pesquisa era composto de três animais de pelúcia em tamanho pequeno, sendo um urso, uma ovelha e um elefante, e 40 fichas redondas azuis com o mesmo tamanho, espessura e cor (Figura 1).

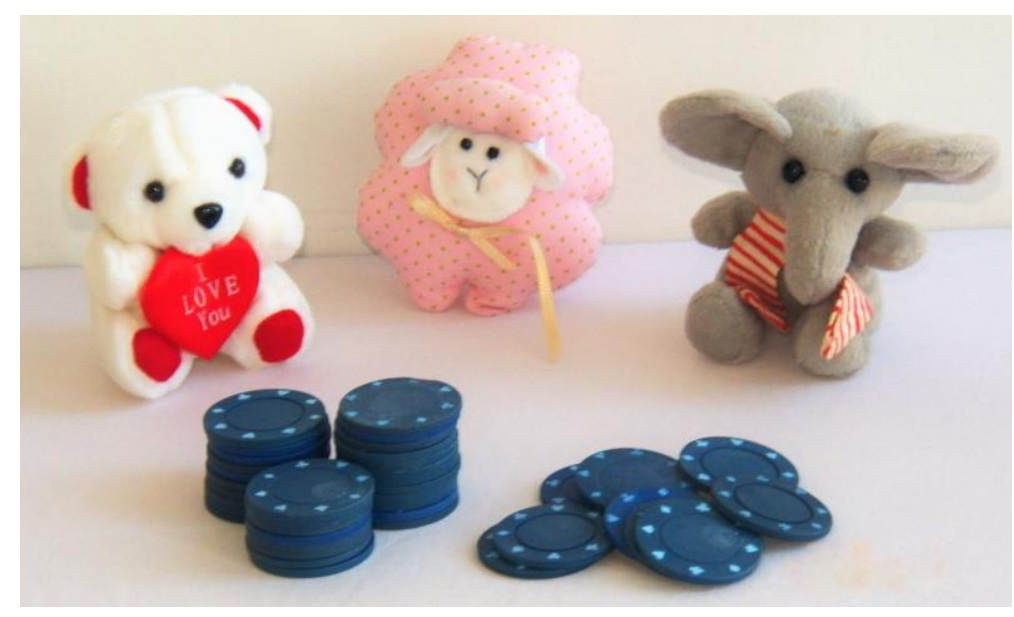

Figura 1: Avaliação das competências e dificuldades conceituais sobre número, grupo CIMETE.

A aplicação da avaliação deveria seguir o proposto pelo grupo CIMETE. De acordo com a proposta, as fichas devem ser distribuídas pela pesquisadora aos animais de pelúcia da seguinte forma: 2 fichas para o urso, 3 fichas para a ovelha e 7 fichas para o elefante. Então, solicita-se à criança que descreva o que ela percebe da situação proposta. Após a descrição, 
questiona-se ao aluno quem tem mais fichas e com ele pode perceber isto. Ao final, pede-se que o aluno deixe todos os bichos com a mesma quantidade de fichas. Mediações são realizadas quando o aluno demonstrar necessidade.

Para avaliar a capacidade dos alunos de resolver problemas, foi escolhido um quebracabeça ou desafio, sendo analisadas as estratégias utilizadas e o tempo disposto. Nesta atividade o aluno dispõe de uma figura composta por duas formas geométricas: um triangulo e um quadrado, formando uma casa. A imagem é acompanhada de 10 peças (Figura 2) distintas que podem montar a imagem de 3 formas diferentes (Figura 3). Todas as peças são entregues aos alunos que deve escolher aquelas que considera mais adequadas para montar a imagem. As peças selecionadas pelo aluno são retiradas pela pesquisadora, então, solicita-se que ele monte novamente a figura com as peças restantes. $\mathrm{O}$ material foi produzido pela pesquisadora utilizando folhas de EVA vermelho e papel cartão amarelo e tem o tamanho de uma folha A4.

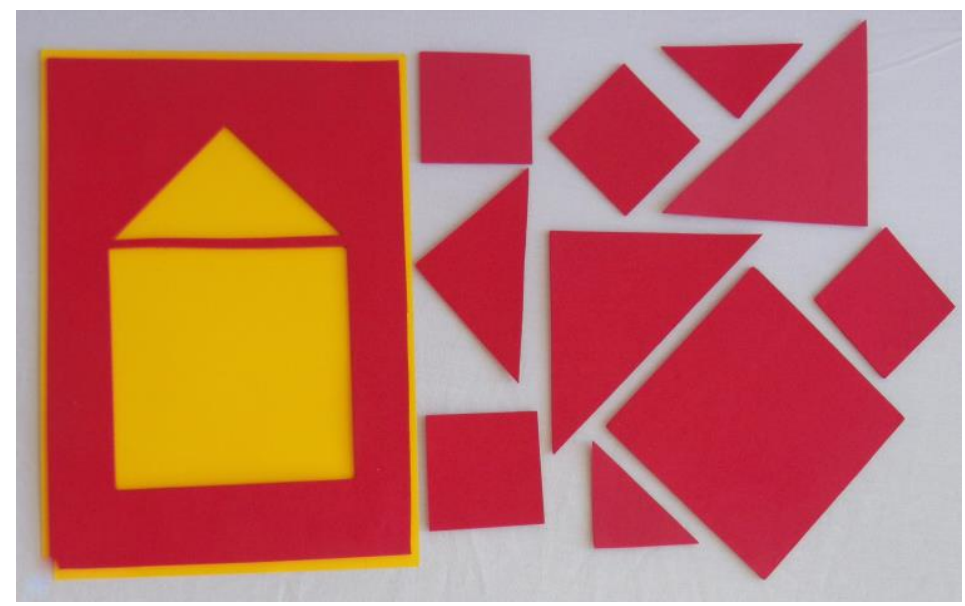

Figura 2: Quebra-cabeça com peças.

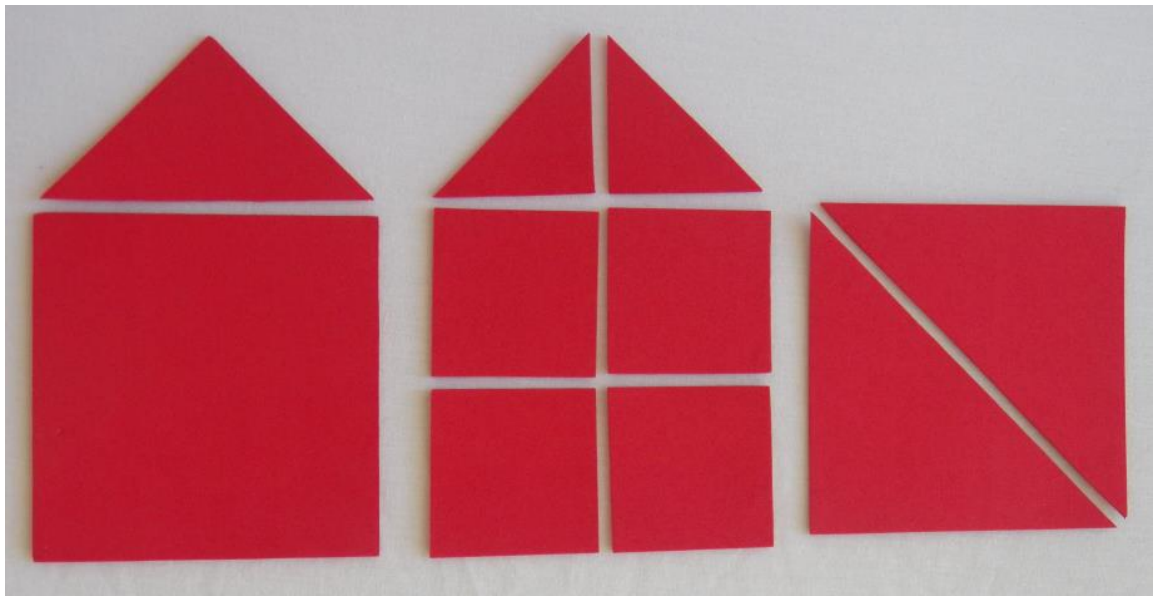

Figura 3: Montagem do quebra-cabeça. 
Esta atividade foi selecionada para avaliar o raciocínio, a reflexão, a estratégia, o pensamento lógico, bem como os conteúdos matemáticos estabelecidos pelo currículo em movimento da educação infantil relacionados a números e operações:

realização da contagem oral em situações diversas; desenvolvimento de estratégias
pessoais para a resolução de situações problema; atividades que trabalhem o
raciocínio lógico por meio de situações problema e histórias; e comparação de
quantidades, utilizando recursos pessoais, como desenho e correspondência um a
um. (BRASIL, 2010, p. 130).

Por fim, os alunos receberiam uma imagem onde deveriam encontrar os itens solicitados pela pesquisadora. Para esta atividade foi selecionada uma imagem da turma da Mônica ${ }^{1}$, por serem personagens conhecidos das crianças, despertando assim o seu interesse. Desta imagem foram retirados 6 elementos para serem identificados pelos alunos (Figura 4). A atividade deve ser desenvolvida da seguinte forma. A figura é mostrada inicialmente pedindo que o aluno a descreva. Em seguida são apresentadas uma a uma as imagens que ele deve localizar, da mais evidente para aquela mais difícil de localizar.

Esta figura foi retirada de um site de buscas, impressa e plastificada para ficar resistente para o manejo das crianças.

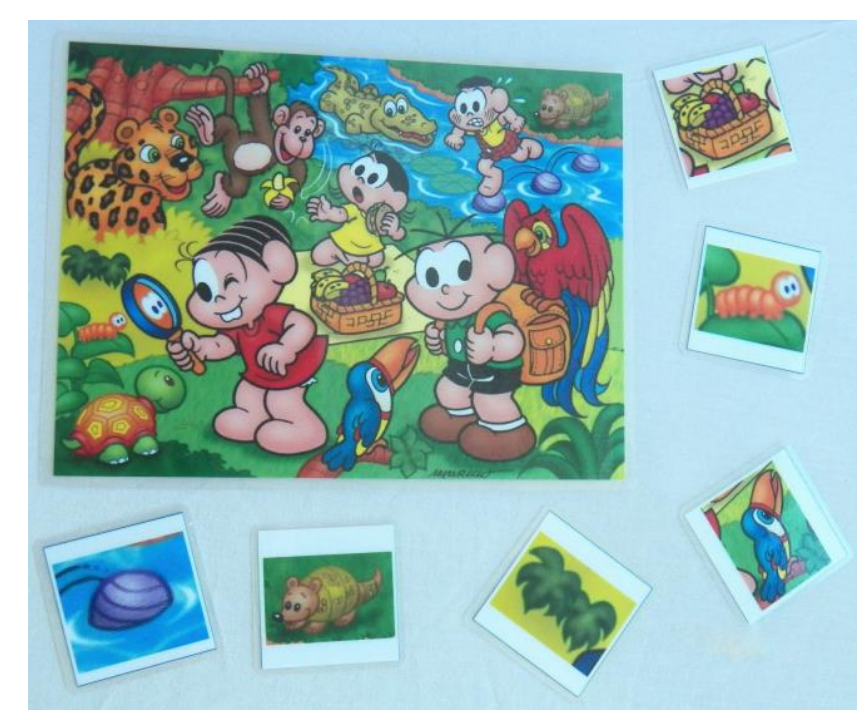

Figura 4: Jogo e imagens para localizar.

\footnotetext{
${ }^{1}$ Personagens criados por Maurício de Sousa Produções Ltda. Disponível para consulta através do endereço http://turmadamonica.uol.com.br/.
} 
Para a avaliação seria registrado quantos itens a criança conseguiria encontrar e o tempo necessário para concluir a tarefa. Este instrumento deve possibilitar a avaliação das seguintes estruturas: a atenção, a discriminação visual, a comparação e a orientação espacial. Além disto, espera-se avaliar conceitos estabelecidos pelo currículo em movimento da educação infantil que constam no subtítulo espaço e forma:

\begin{abstract}
representação espacial (posição de pessoas e objetos: dentro/fora; em cima/embaixo; esquerdo/direito; frente/atrás/ao lado, etc.); orientação espacial em relação a objetos e pessoas; utilização de desenhos, imagens e mapas simples para localizar objetos e pessoas, reconhecimento e organização de objetos por critérios de semelhanças e diferenças, agrupando-os numa categoria (desenvolvimento do pensamento classificatório) (BRASIL, 2010, p. 131).
\end{abstract}

Esperava-se, com esta avaliação proposta, conhecer os sujeitos participantes da pesquisa e analisar a aprendizagem matemática alcançada por estes.

\title{
4.3.2 Jogos utilizados
}

A partir das análises e pesquisas realizadas foram selecionados 5 Jogos de Reflexão Pura infantis para desenvolver nas aulas. Foram considerados Jogos de Reflexão Pura aqueles que não exigiam um conteúdo específico para seu desenvolvimento, dispensam o fator sorte em sua execução e eram jogados por dois oponentes, promovendo a competição.

A seleção dos jogos foi realizada por meio de pesquisa em sites, lojas de brinquedos, livros e periódicos. Incialmente a busca se limitou a jogos voltados para crianças de até 5 anos de idade, porém, devido ao pouco resultado, houve a necessidade de ampliar as buscas para todos os tipos de jogos.

Foram analisados os seguintes aspectos nos jogos encontrados:

1. Se poderia ser jogado entre dois participantes;

2. Se continha algum elemento que dependia do fator sorte;

3. Se apresentava algum conteúdo específico.

Foram então, excluídos os jogos que necessitavam de mais de dois jogadores ou que eram desenvolvidos individualmente e aqueles que apresentavam elementos que dependiam do acaso ou algum conteúdo específico.

Caso os jogos atendessem a estas características, era analisada a possibilidade de o jogo ser adaptado para a faixa etária selecionada e de ser confeccionado pela pesquisadora. 
Ao final, os jogos selecionados foram analisados para verificar quais habilidades matemáticas estimulariam, sendo então escolhidos 5: Jogo da Velha, Cara a Cara, Jogo da Memória, Mancala e Pontinhos. Destes, os quatro primeiros seriam aplicados em sala com a turma, e o último ficaria reservado para ser utilizado na substituição de alguma atividade caso esta não desperte interesse dos alunos.

Os materiais disponibilizados para os alunos foram adaptados e confeccionados pela pesquisadora para atender às necessidades e características da faixa etária escolhida. Para cada jogo seria confeccionado uma versão em tamanho grande para desenvolver com a turma toda em conjunto no primeiro momento e 5 versões menores para que os alunos joguem em grupos. Os jogos seriam confeccionados com apelo infantil, estimulando o interesse dos alunos nestes.

\section{a) Jogo da Velha}

Esta atividade é composta por um tabuleiro com três linhas e três colunas e jogada entre dois competidores. Cada competidor escolhe uma marcação e na sua vez sinaliza uma das casas do tabuleiro com a marcação escolhida. O objetivo é completar uma linha com três marcações na diagonal, horizontal ou vertical.

O jogador que conseguir completar primeiro uma linha é o vencedor. Caso o jogo encerre sem que nenhum dos participantes consiga concluir a linha, este é considerado empatado. Este jogo desenvolve a reflexão, a atenção, a discriminação visual, a estratégia e o pensamento lógico.

O jogo utilizado nesta pesquisa foi produzido utilizando EVA, TNT e velcro, tanto a versão maior quanto a versão reduzida. A marcações tradicionais, " $X$ " e "O" foram substituídos por sapos e joaninhas para ficar mais atrativo aos alunos (Figuras 5 e 6). O jogo maior tinha o tamanho de $60 \mathrm{~cm}$ X $60 \mathrm{~cm}$, e a versão menor $30 \mathrm{~cm}$ X $30 \mathrm{~cm}$. 


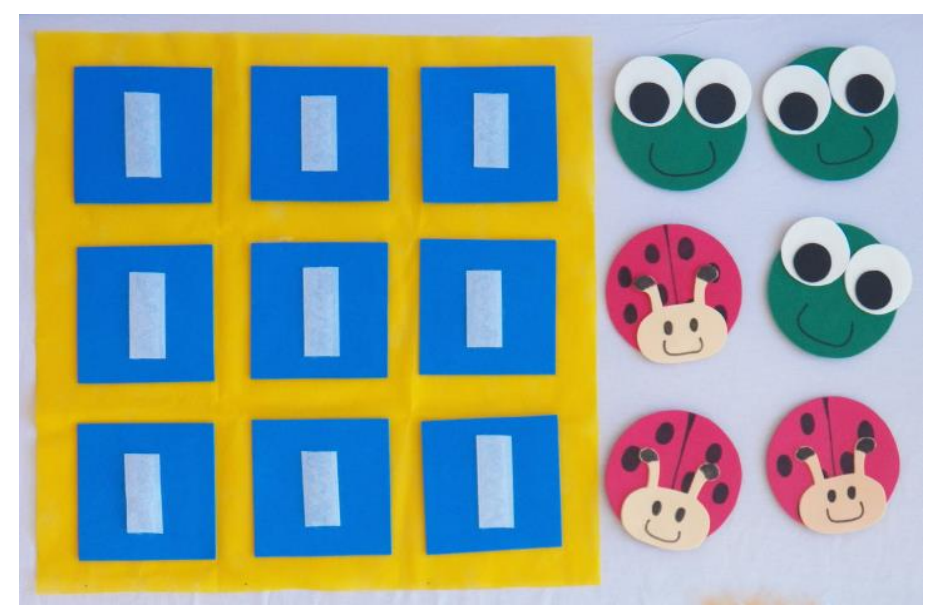

Figura 5: Jogo da Velha em tamanho grande.

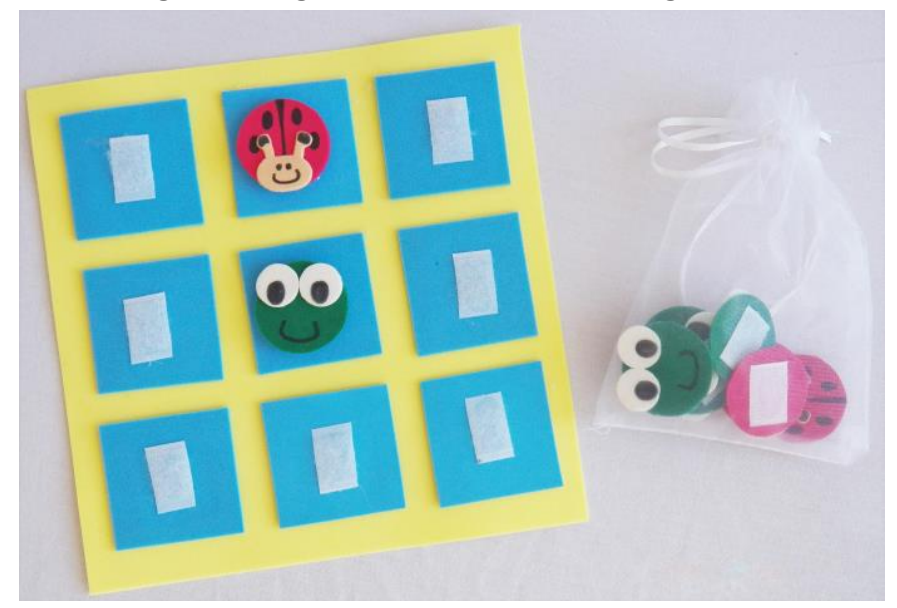

Figura 6: Jogo da Velha em tamanho pequeno.

b) Jogo da Memória

O Jogo da Memória é composto por 10 pares de imagem iguais ou que se complementam. As imagens são embaralhadas e dispostas inicialmente com a face para cima para que os jogadores observem a sua localização. Depois, as cartas serão viradas com a face para baixo e cada jogador, na sua vez, deverá escolher um par de cartas, virando-as com a face para cima. Caso o jogador vire duas cartas iguais ou que se complementem ele as mantem e pode repetir a jogada. Se as cartas não formem um par, ele passa a vez para o jogador seguinte. Quando o último par de cartas for virado o jogo é finalizado e são computadas as cartas de cada participante, comprando a quantidade com os demais. Vence o jogador que tiver conseguido mais pares.

De acordo com suas regras originais, este não poderia ser considerado um Jogo de Reflexão Pura, porém, devido à pouca variedade de jogos encontrados, houve necessidade de 
adaptá-lo para que se adequasse ao conceito aqui trabalhado. Assim, no decorrer das aulas o Jogo da Memória seria trabalhado apenas entre dois jogadores, e ambos teriam a oportunidade de ver a localização das peças antes do início do jogo, possibilitando a criação de estratégias e eliminando o acaso.

Este jogo estimula as habilidades memória, a associação, o pareamento, a discriminação visual, a contagem e o pensamento lógico e as estruturas matemáticas comparação e correspondência.

O Jogo da Memória em tamanho grande foi produzido com papelão e cartolinas, além da imagem impressa dos animais que formariam os pares: girafa, cachorro, sapo, gato, macaco, tigre, urso, porco, leão e zebra. Foram produzidos 10 pares, com o total de 20 cartas, que apresentam o formato quadrado com o tamanho de aproximadamente $15 \mathrm{~cm} \mathrm{X} 15 \mathrm{~cm}$ (Figura 7).

Já a versão menor foi adquirida em loja de brinquedos educativos, pois é produzido em madeira, sendo um material mais durável e resistente (Figura 8). Os jogos adquiridos apresentavam as temáticas "animais" e "inglês e português", sendo cada um composto por 20 pares, totalizando 40 peças. Apesar de um dos jogos utilizados ter a temática "português e inglês", isto não influenciou no jogo para os alunos do $2^{\circ}$ período, visto que as imagens utilizadas eram grandes e claras e, como os alunos não são alfabetizados, eles se guiaram pelas imagens para jogar. Em todas as versões utilizadas, os pares são formados por imagens idênticas.

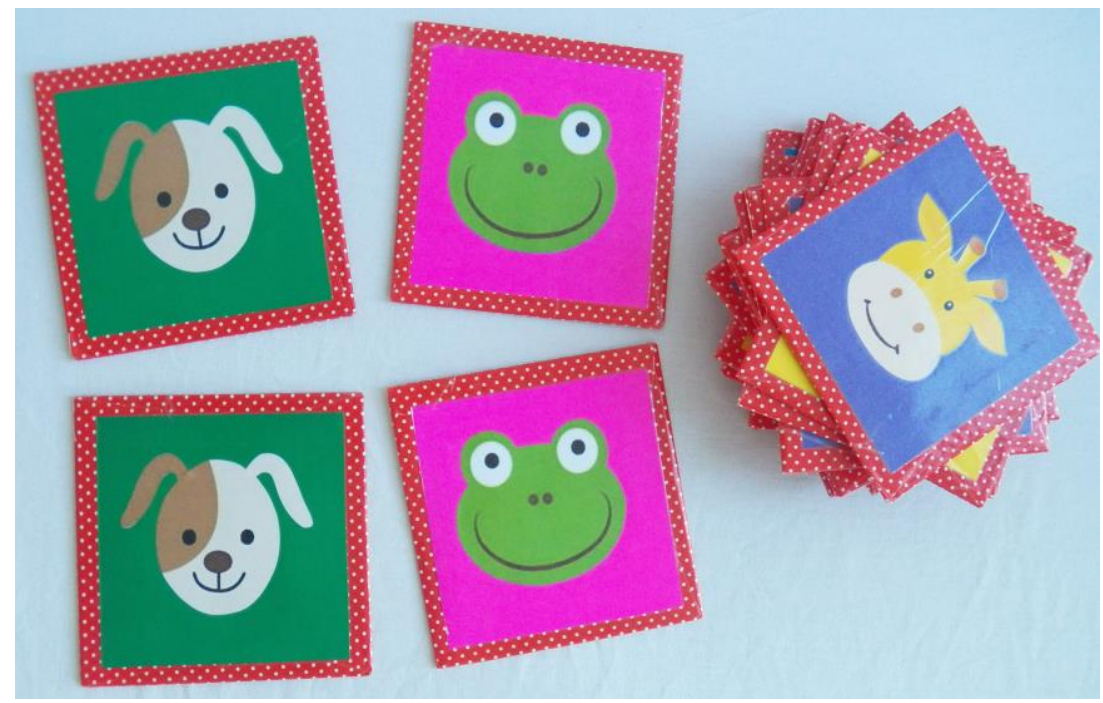

Figura 7: Jogo da Memória em tamanho grande. 


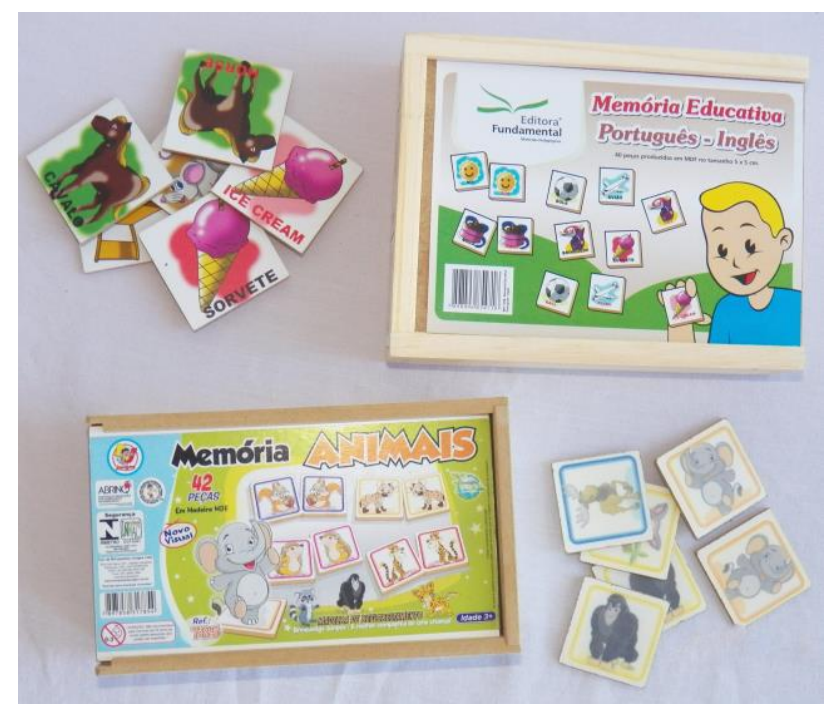

Figura 8: Jogo da Memória em tamanho pequeno.

c) Cara a $\mathrm{Cara}^{2}$

O jogo é para dois participantes ou equipes e é composto por 2 quadros com diversas imagens de personagens com diferentes características, com seus respectivos nomes escritos abaixo. Cada jogador, na sua vez, deverá selecionar uma das imagens sem que o seu adversário veja. Os participantes deverão, então, tentar descobrir qual é o personagem escolhido pelo adversário fazendo, alternadamente, questões com respostas SIM e NÃO.

Como os participantes da pesquisa não são alfabetizados ainda, o jogo foi confeccionado pela pesquisadora utilizando personagens cujos nomes os alunos já conhecessem. Para compor o jogo foram utilizadas 10 imagens, dispostas em um quadro de 2X5. Os personagens selecionados para o jogo foram: anjo, bailarina, bombeiro, cozinheira, fada, jogador de futebol, palhaço, pirata, policial e vaqueira. As imagens foram selecionadas em um site de busca, impressas em cores e em alta qualidade e plastificadas para torná-las mais resistentes. Para a versão maior as cartas foram plastificadas individualmente e fixadas em um pedaço de TNT (Figura 9). Na versão menor as imagens foram coladas em papel cartão antes de serem plastificadas (Figura 10).

\footnotetext{
${ }^{2}$ O Cara a Cara foi desenvolvido com base em regras de um jogo atualmente comercializado, disponível para consulta através do endereço http://www.estrela.com.br/brinquedo/cara-a-cara/. Suas regras e formato foram adaptados para atender aos alunos da faixa etária selecionada pela pesquisa.
} 
Para cada tabuleiro também foram confeccionadas cartas com os personagens do mesmo tamanho das dispostas. Para jogar tanto com o tabuleiro grande quanto com o pequeno, os alunos riscavam com marcador de quadro branco os personagens descartados, o que, ao final do jogo, era facilmente apagado com um pedaço de tecido.

De acordo com Cunha e Nascimento (2005) este jogo favorece a linguagem, a discriminação visual, a atenção e a classificação. Além disso, também estimula o pensamento lógico, a estratégia, a reflexão e a comparação.

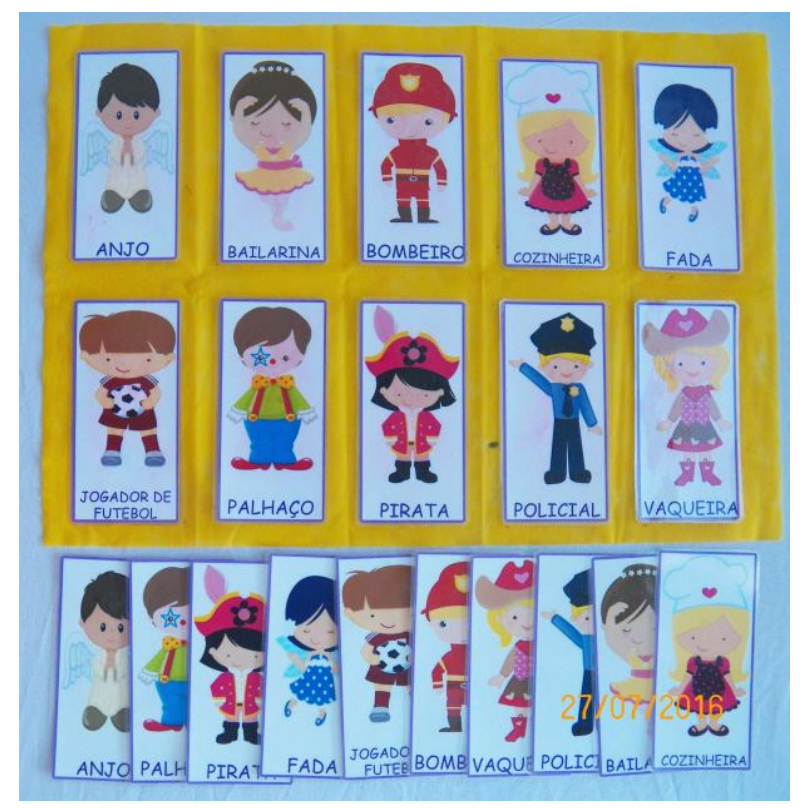

Figura 9: Jogo Cara a Cara em tamanho grande.

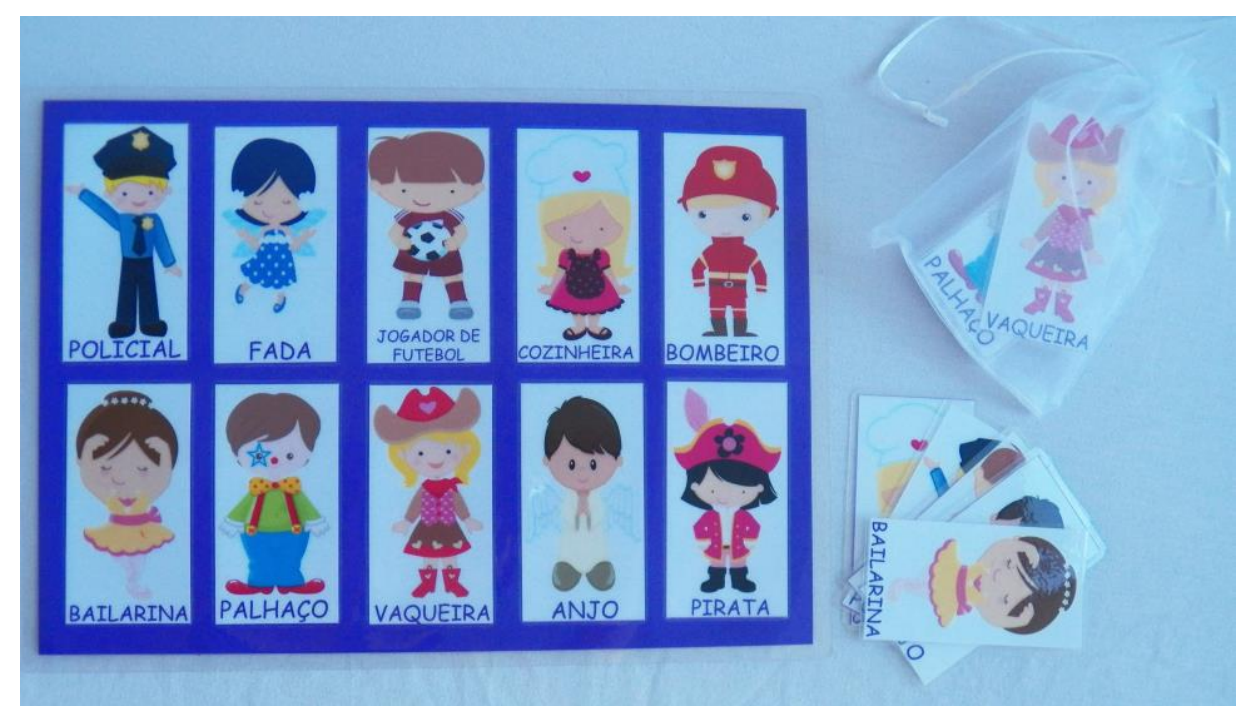

Figura 10: Jogo Cara a Cara em tamanho pequeno. 
d) Mancala

Este jogo é desenvolvido em um tabuleiro com 14 espaços, denominados cavas, e utilizando 48 sementes. Há, para cada jogador, 6 cavas pequenas e 1 grande, sendo que o jogo ocorre nas menores e a maior é utilizada para armazenamento das sementes de cada jogador. Para iniciar o jogo, são colocadas 4 sementes em cada cava e cada jogador escolhe um lado do tabuleiro para jogar, ficando também com a cava maior que está posicionada a sua direita, onde serão guardadas suas sementes. Cada um em sua vez deverá escolher uma das cavas, recolher as sementes que estão nesta e distribui-las pelos espaços seguintes, colocando uma semente em cada cava seguindo o sentido horário. O objetivo deste jogo é juntar o maior número de sementes.

Cunha e Nascimento (2005) dizem que este jogo estimula a construção de estratégias e a contagem. Este também estimula a reflexão, a atenção e o pensamento lógico.

O jogo utilizado nesta pesquisa foi produzido utilizando-se caixa de ovo, tintas azul e amarela, recipientes plásticos coloridos nas mesmas cores das tintas e miçangas grandes. A versão maior utilizou uma caixa de ovos inteira, com 12 espaços, e a menor meia caixa, com 6 espaços (Figura 11). Para trabalhar com crianças de 5 anos, o tabuleiro será sinalizado com as cores azul e amarelo, uma para cada participante, auxiliando assim a visualização dos jogadores.

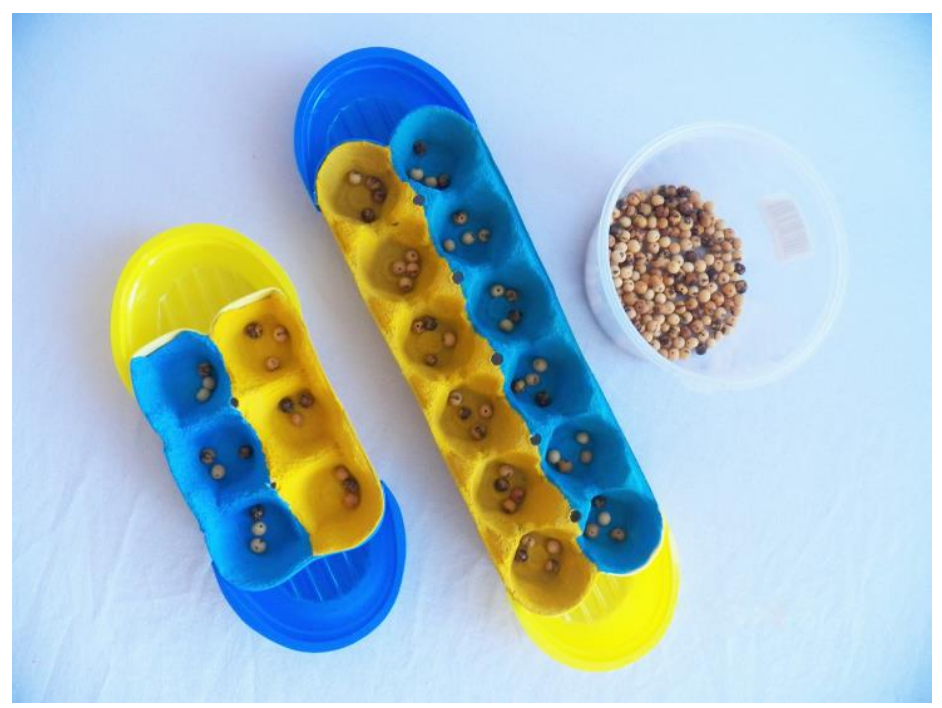

Figura 11: Jogo Mancala em tamanhos pequeno e grande. 
e) Pontinhos

Para este jogo é necessário apenas um tabuleiro, composto por pontos dispostos em linhas e colunas. Pode ser jogado por dois ou mais times ou competidores e tem o objetivo de formar quadrados antes de seu adversário. A cada jogada o competidor traça uma linha ligando dois pontos dispostos, sendo que, ao fechar um quadrado ele o marca com uma letra ou símbolo e pode jogar novamente, o que possibilita a marcação de muitos pontos em apenas uma jogada. O jogo termina quando todos os pontos são ligados e vence aquele participante que tiver mais quadrados.

O tabuleiro deste jogo pode ser confeccionado com qualquer quantidade de pontos, desde que dispostos em forma retangular, sendo que o jogo fica mais extenso e demorado conforme aumenta o tamanho do tabuleiro. Para esta pesquisa foram utilizados dois tamanhos de tabuleiro: $4 \times 4$ e $5 \times 5$. Os tabuleiros utilizados foram impressos com a orientação para o traçado dos alunos em tamanho grande e pequeno, fixados em papel cartão e plastificado. Para jogar os alunos riscavam as linhas utilizando marcador para quadro branco, apagando com um pedaço de tecido ao final (Figuras 12 e 13).

Este jogo estimula a construção de estratégias e a contagem, além de a reflexão, a atenção e o pensamento lógico.

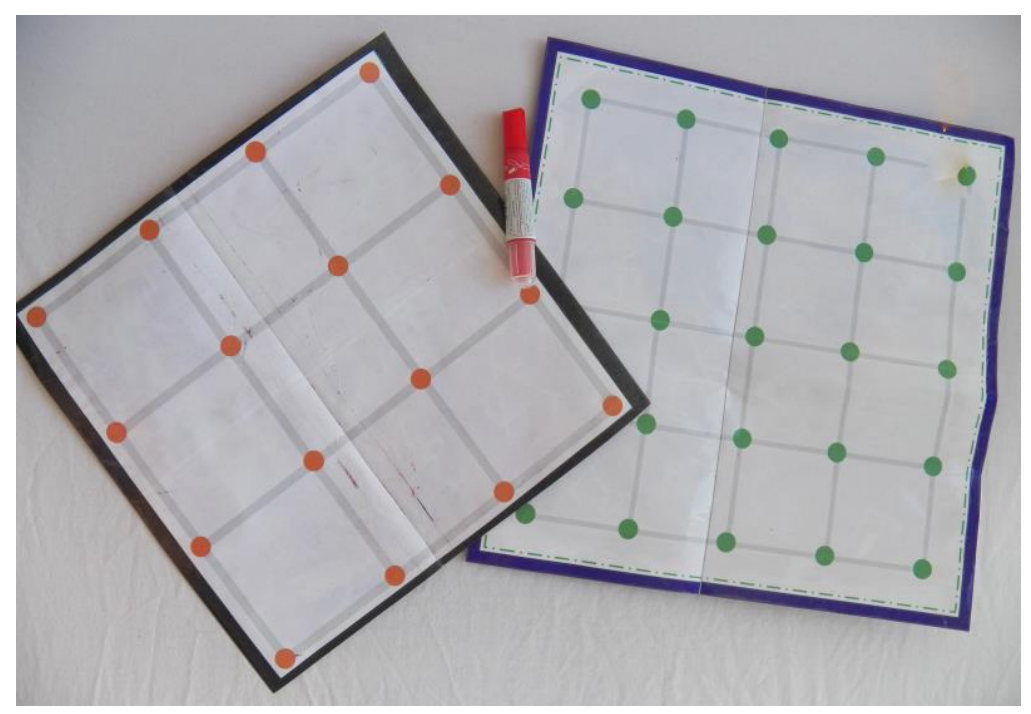

Figura 12: Jogo Pontinhos em tamanho grande. 


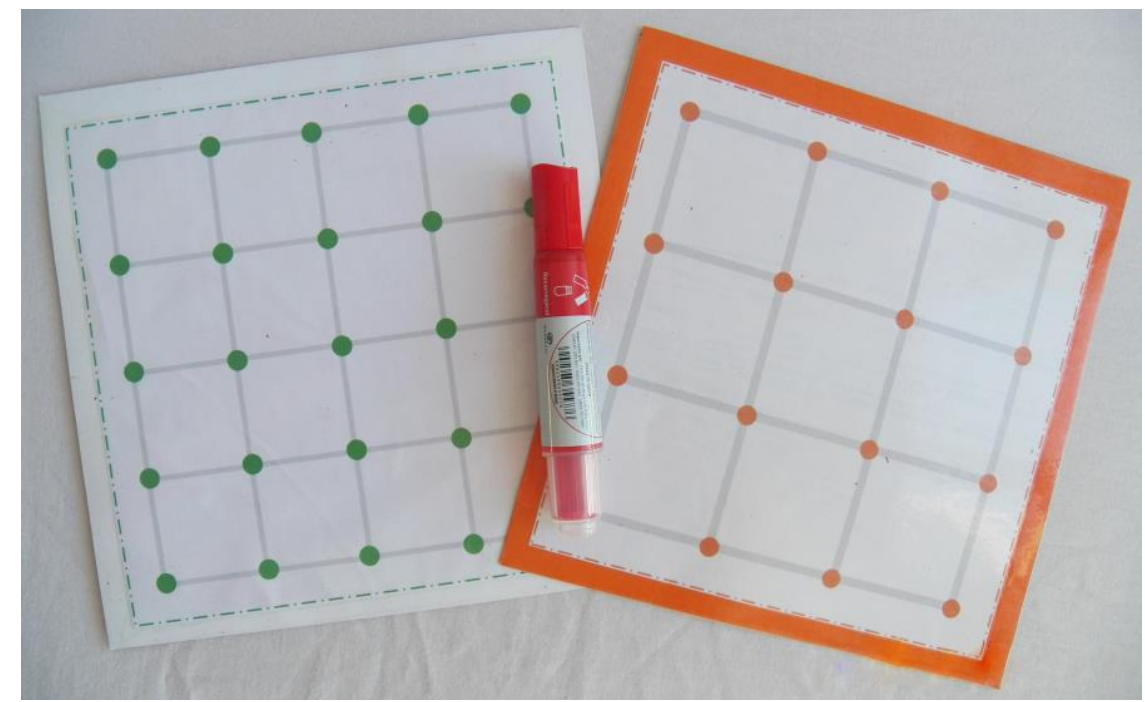

Figura 13: Jogo Pontinhos em tamanho pequeno.

\section{RESULTADOS E ANÁLISES}

Inicialmente, a proposta era começar a pesquisa no mês de fevereiro do ano de 2016, juntamente com o ano letivo, quando ocorreria o contato inicial com os alunos e a professora. Esperava-se que a turma fosse composta por 24 alunos e que frequentasse o período vespertino, pois acredita-se que o ambiente escolar é mais calmo neste horário.

De acordo com o planejamento inicial, a pesquisadora deveria estar em contato com a turma mesmo antes de iniciar a pesquisa, participando ativamente da primeira semana de aula, denominada "semana de adaptação" para os alunos da educação infantil. Tal atitude promoveria a interação entre a pesquisadora e os estudantes.

Após esta semana, iniciariam os encontros com a turma. Os encontros deveriam ocorrer na frequência de 2 vezes por semana e com duração de uma hora cada, preferencialmente as terças e quintas ao final da aula, no horário de 16:30h às 17:30h, e sem a presença da professora regente da turma. O início previsto para o primeiro encontro seria 14 de março de 2016. As aulas com os jogos prosseguiriam seguindo o proposto no planejamento diário (APÊNDICE A). Os encontros com os alunos seriam registrados em áudio, havendo um gravador alocado em cada grupo, e todas as observações realizadas no decorrer da pesquisa anotadas em um diário de campo. Também haveria gravação em vídeo das aulas. As gravações de vídeo registrariam os momentos de jogo com toda a turma e, posteriormente, as interações entre os grupos de alunos, alternando entre os grupos a cada aula. 
Apesar da busca por seguir o planejamento inicial proposto, ao aplicar o planejamento proposto para a pesquisa, foi necessário realizar alterações para que esta se adequasse à realidade da escola escolhida. Assim, com as alterações que ocorreram no decorrer de seu desenvolvimento, a pesquisa seguiu o cronograma exposto no Apêndice F.

\subsection{Contato inicial com os sujeitos}

A turma onde ocorreu a pesquisa foi escolhida em uma escola de educação infantil situada na cidade de Sobradinho, no Distrito Federal. Tal instituição foi selecionada por ser um local onde a pesquisadora já havia trabalhado anteriormente. Era necessário que fosse uma turma de $2^{\circ}$ período da Educação Infantil e incialmente, como já exposto, esperava-se que a turma fosse formada por 24 alunos e estudasse no período vespertino. Porém, como a escola é pequena, houveram poucas opções a disposição para a escolha da pesquisadora. A escola contava com apenas quatro turmas de $2^{\circ}$ período, sendo duas no turno da manhã e duas no turno vespertino.

A escola em questão era adaptada, dispondo apenas de quatro salas de aula identificadas pelas cores amarela, vermelha, azul e verde. Dentre as salas disponíveis havia uma que, por ser muito pequena, dificultava a aplicação dos jogos, a sala vermelha. Assim, a turma selecionada não poderia ter aulas nesta sala. No período matutino as turmas de $2^{\circ}$ período ocupavam as salas azul e verde, e vespertino as salas verde e vermelha. Foi excluída, então, da seleção a turma que ocupava a sala vermelha. A turma do turno vespertino que ocupava a sala verde havia passado por uma mudança de professora, recebendo uma nova profissional. Em conversa com a diretora da instituição, ela aconselhou a não acompanhar esta turma, por não saber como seria a reação da nova professora à pesquisa. Então, a escolha ficou entre as duas turmas do turno matutino, ambas turmas de inclusão, recebendo alunos com necessidades educacionais especiais.

Ambas as turmas eram compostas por 14 alunos, sendo que na sala azul havia uma criança com diagnóstico de paralisia cerebral, que já tinha contato com a pesquisadora, e a turma da sala verde recebeu uma aluna com síndrome de down, que era nova na escola. Assim, ficou clara a decisão pela turma da sala azul, visto que o aluno se sentiria mais confortável com a presença da pesquisadora. A diretora também interferiu nesta escolha, sugerindo que a pesquisa fosse realizada com a turma da sala azul, pois nesta turma haviam 
mais alunos que já frequentavam a escola no ano anterior e a professora estava mais interessada em receber a pesquisa. As professoras já tinham conhecimento da proposta da pesquisa e se demonstraram abertas a participar.

Após a seleção da turma foi feito o contato com a professora regente. Ela recebeu muito bem a proposta e a pesquisadora, se demonstrando animada em participar e se colocando à disposição para o que fosse necessário. Foi então, acordado com a professora como seria o cronograma da pesquisa (APÊNDICE A). Inicialmente, dia 16 de março de 2016, seriam enviados os Termos de Consentimento Livre e Esclarecido aos pais, com auxílio da professora. A professora e a diretora da escola também receberam e assinaram termos concordando com a aplicação da pesquisa (APÊNDICES C e D). Na primeira semana, de 17 a 24 de março de 2016, os alunos seriam avaliados individualmente. Nas 10 semanas seguintes, no período entre 29 de março e 02 de junho de 2016, a pesquisadora entraria em sala 2 vezes por semana, por uma hora cada, sempre no horário de $10 \mathrm{~h}$ às $11 \mathrm{~h}$ para aplicar os jogos. $\mathrm{O}$ horário foi estabelecido pela professora, sendo o tempo entre o lanche dos alunos (9:30h) e o parque (11h). Após este período, no decorrer de uma semana, as avaliações individuais seriam reaplicadas.

A pesquisadora deu à professora a opção de estar em sala no horário da pesquisa ou sair no horário da pesquisa. A professora preferiu permanecer em sala, acompanhando a dinâmica da aplicação dos jogos e contribuindo com o que fosse necessário.

Foi solicitado à professora que não usasse o tempo da pesquisa como "prêmio" ou “castigo" para os alunos, e ela concordou com a proposta. Também ficou acordado que, sempre que houvesse um impedimento à aplicação da pesquisa a professora avisaria à pesquisadora, que iria reporia a aula posteriormente, fazendo os devidos ajustes ao calendário.

\subsection{Contato com os responsáveis}

Após o contato com a direção da escola e a professora regente de turma, foi realizado o contato com os responsáveis dos alunos. A diretora propôs que a pesquisadora apresentasse a proposta da pesquisa aos pais na primeira reunião de pais do ano. Neste momento, foi informado aos pais que seria realizada uma pesquisa na escola, explicitando os alunos que participariam desta e seus objetivos. Também foi informado que receberiam os Termos de Consentimento Livre e Esclarecido, TCLE (APÊNDICE B), por meio da agenda dos alunos. 
Para aguardar a reunião de pais, que ocorreu dia 23 de março, o início da pesquisa foi adiado em uma semana.

No dia seguinte à reunião de pais, foi enviado via agenda para a turma selecionada para a pesquisa o TCLE juntamente com um bilhete. O TCLE foi enviado em duas vias para assinatura e devolução de uma destas.

O bilhete continha o seguinte texto:

Srs pais e/ou responsáveis, sou professora da secretaria de educação, lotada nesta escola, e estou atualmente afastada para concluir o meu Mestrado em Educação na Universidade de Brasília. Para tal, preciso realizar uma pesquisa em ambiente escolar. Por isso, estarei acompanhando a turma do seu filho no decorrer deste primeiro semestre letivo, propondo jogos com o objetivo de desenvolver a matemática. $\mathrm{O}$ documento em anexo apresenta mais informações sobre a pesquisa. Solicito que assine o documento e envie uma via novamente para a escola. A segunda via servirá para sua consulta caso necessário. Estarei à disposição para tirar quaisquer dúvidas, podem entrar em contato comigo através do meu e-mail ou utilizando a agenda do seu filho.

Tal bilhete era assinado pela pesquisadora, que fornecia, ao final, seu endereço eletrônico.

\subsection{Descrição da turma}

A turma selecionada para a pesquisa era composta de 14 alunos regulares, sendo uma turma de inclusão. Continha 8 meninas e 6 meninos, dentre estes um aluno com necessidades educacionais especiais (ANEE). Os alunos tinham 5 anos de idades completos na data da pesquisa, e a maior parte destes era oriunda do ano anterior, sendo que já conheciam os colegas, a professora e a pesquisadora. Tratava-se de uma turma tranquila e participativa e apresentavam um bom relacionamento entre pares e com a professora.

O aluno que apresentava necessidade educacionais especiais era o Marcelo. Este foi diagnosticado com paralisia cerebral triplégica e transtorno cognitivo, sendo incluso na secretaria de educação como deficiente físico de média necessidade. Marcelo apresentava dificuldade para compreender e acompanhar as atividades propostas, além de limitação da motricidade fina.

De acordo com o relato da professora, a turma gosta de ouvir histórias e recontá-las. Os alunos interagem bem com os colegas nos momentos de recreação, compreendem com facilidade as regras propostas e as respeitam. Eles realizam as atividades propostas com 
capricho e atenção, e a maior parte dos alunos reconhece e identifica as letras do alfabeto e os números. Gostam de brincar com massinha de modelar, jogos de encaixa e quebra-cabeças.

No primeiro contato da pesquisadora com os alunos foi possível notar que estes são receptivos à novas pessoas e propostas, além de respeitosos e atenciosos. Também ficou claro que a turma apresenta independência ao realizar tarefas rotineiras, como por exemplo a organização da rodinha, o arquivamento das atividades realizadas e acesso, cuidado e guarda dos materiais utilizados.

A turma demonstrou interesse imediato na proposta dos jogos, mesmo ainda na fase da avaliação inicial, quando foram chamados para "jogar” individualmente com a pesquisadora.

Importante salientar que para preservar a identidade dos alunos e garantir sua privacidade, o que lhes foi assegurado pelo TCLE, foram utilizados nomes fictícios no decorrer de toda pesquisa ao descrever as atividades desenvolvidas. Os nomes foram selecionados mantendo o gênero do aluno em questão.

\subsection{Avaliação inicial}

A avaliação inicial ocorreu em três dias diferentes, e os alunos foram avaliados conforme a professora os enviava para a pesquisadora, seguindo a ordem estabelecida por ela. Como a escola não tem espaço suficiente, os alunos foram avaliados em uma mesa disposta no pátio. As avaliações iniciavam às 10 horas e finalizavam no momento em que a turma ia para o parque. No primeiro dia, 25 de março de 2016, foram atendidos 4 alunos, no segundo dia, 28 de março de 2016, 9 alunos foram avaliados e restou apenas 1 aluno para o último dia, 29 de março de 2016, que também foi o primeiro dia de aplicação dos jogos.

As avaliações foram registradas em vídeo, além de a pesquisadora anotar suas observações em diário de bordo.

Antes de iniciar as avaliações, a pesquisadora foi em sala conversar com os alunos e se presentar para eles. A maior parte dos alunos já a conhecia de seu trabalho na escola no ano anterior. Os alunos se mostraram empolgados a iniciar os encontros e ansiosos por sua vez de sair da sala para encontrar a pesquisadora.

A presença da câmera não atrapalhou a avaliação. Ao receber cada criança, a pesquisadora explicou que o encontro seria gravado, mas que não havia motivo para vergonha ou preocupação, pois essa gravação só seria assistida por ela mesma. Alguns estudantes se 
mostraram tímidos à gravação, mas se distraiam quando eram apresentados aos objetos de avaliação, não mais se mostrando preocupados com a gravação.

A avaliação começou com a aplicação avaliação das competências e dificuldades conceituais sobre o número do grupo CIMETE. A pesquisadora apresentou os bichinhos de pelúcia para os alunos, o que despertou o interesse e atenção destes. A avaliação seguiu com o quebra-cabeças e foi finalizada com a imagem da turma da Mônica ${ }^{3}$. Apenas uma aluna se mostrou receosa em participar da avaliação, mas se interessou pelos bichinhos de pelúcia e participou normalmente.

Apesar de alguns estudantes se mostrarem tímidos, os alunos relataram ter gostado da avaliação, e era possível perceber isso quando estes contavam para os demais colegas a experiência que tiveram.

Como o objetivo destas atividades era avaliar o aluno e seriam utilizadas duas vezes, uma ao início e outra ao final da pesquisa, as respostas dadas pelos alunos não foram corrigidas pela pesquisadora no primeiro momento. Eram aceitas as respostas que eles apresentassem.

\subsection{Aplicação dos jogos}

Foram inicialmente selecionados 4 Jogos de Reflexão Pura para utilizar com os alunos: Cara a Cara, Jogo da Memória, Jogo da Velha e Mancala. Os jogos foram selecionados após uma pesquisa realizada em sites de jogos e brinquedos, bem como em livros com esta temática. Todos os jogos passaram por adaptações para atender a idade proposta e foram confeccionados pela pesquisadora.

A pesquisadora decidiu aplicar os jogos do mais simples para o mais complexo sendo inicialmente esta ordem: Memória, Jogo da Velha, Cara a Cara, Mancala. Após analisar novamente houve apenas uma mudança nesta ordem, pois o Jogo da Velha era menos conhecido dos alunos e iniciar a pesquisa com este poderia despertar mais o interesse deles. Ficou, então, definida a seguinte ordem para a aplicação dos jogos: Jogo da Velha, Memória, Cara a Cara, Mancala.

\footnotetext{
${ }^{3}$ Personagens criados por Maurício de Sousa Produções Ltda. Disponível para consulta através do endereço http://turmadamonica.uol.com.br/.
} 


\subsubsection{Jogo da Velha}

A primeira aula ocorreu dia 29 de março de 2016. A pesquisadora solicitou aos alunos que se sentassem em rodinha no centro da sala e explicou o que aconteceria. A recepção dos alunos aos jogos e à professora foi muito boa. Eles se demonstraram ansiosos e empolgados para jogar. Apenas dois alunos relataram conhecer o jogo.

Após explicar as regras dos jogos, os alunos sugeriram uma competição meninos contra meninas para jogar. Foram apresentados os objetivos e regras do jogo, bem como as estratégias que poderiam ser usadas. A pesquisadora explicou que os alunos deveriam formar uma linha reta e não deixar o seu adversário completar sua linha. Ao jogar, os alunos inicialmente colocavam as peças aleatoriamente. A pesquisadora interviu, explorando o jogo em grupo estimulando os alunos a refletir antes de fazer as jogadas.

No decorrer das aulas os alunos passaram a refletir mais antes de cada jogada, mas focavam em apenas um objetivo: completar a linha para ganhar o jogo ou atrapalhar o adversário. A maioria dos alunos buscava "atrapalhar" o colega ao invés de "ganhar", deixando passar algumas possibilidades de concluir a linha.

Durante os jogos os alunos demonstraram ter dificuldade em perceber a linha quando era formada na diagonal. Algumas vezes, mesmo com a linha diagonal formada, diziam que o jogo estava empatado.

Foi possível perceber, desde a primeira aula, que além de explorar as regras do jogo proposto, seria necessário trabalhar a relação dos estudantes com os jogos de forma geral. Os alunos não conseguiam esperar sua vez de jogar e queriam fazer duas ou mais jogadas em sequência. Também não demonstravam cuidado ao manusear o jogo e, durante a competição davam dicas para ajudar aos competidores, mesmo quando eram de outra equipe, demonstrando não reconhecer a formação das equipes. Mas, o principal, era que os alunos precisavam aprender a lidar tanto com a vitória quanto com a derrota, pois se mostravam revoltados quando perdiam, brigando com o último jogador do time a fazer uma jogada, ou gozavam os demais colegas quando venciam.

No decorrer das aulas, apenas uma aluna em uma aula não quis jogar, a Sara, na terceira aula. Nas demais aulas esta aluna se divertiu jogando novamente.

Este jogo foi utilizado por 5 aulas, como previsto. Cada aula demorou cerca de 45 minutos e foram ministrados de acordo com as descrições a seguir. 
A primeira aula, ministrada no dia 29 de março, teve 12 alunos presentes. Neste primeiro momento foi utilizado durante toda a aula o jogo em versão grande, estando a turma dividida em duas equipes, conforme explicitado acima.

A segunda aula ocorreu no dia 31 de março, com a presença de 11 alunos. Neste momento iniciou-se com o jogo grande e todos os alunos em rodinha. Foram relembradas as regras durante o jogo em equipes e, posteriormente, introduzido o jogo em versão menor para jogar em quartetos, sendo duplas contra duplas. Os grupos foram separados e os alunos jogaram em suas mesas. Porém, foi difícil administrar o jogo individual. A todo momento os alunos se levantavam e iam até a pesquisadora para falar sobre o jogo ou reclamar do comportamento do seu parceiro. Os alunos também tiveram dificuldade em jogar sem a mediação da pesquisadora. Eles jogavam duas vezes seguidas, trocavam as peças de lugar ou não alternavam entre os jogadores da dupla. Ficou clara a dificuldade que os alunos tinham de administrar a alternância.

Nesta aula, um grupo de alunos, após tentar jogar algumas partidas, desistiu e começou a brincar com os personagens do jogo, o sapo e a joaninha. Ao final desta aula, ficou claro que os alunos ainda não tinham compreendido bem as regras do jogo proposto, e a necessidade de relembrar as regras novamente na aula seguinte.

Este primeiro momento dos alunos com os jogos menores houve o registro em áudio de cada grupo, assim como planejado incialmente. Porém, analisando os arquivos em áudio notou-se que estes não contribuíam para a pesquisa, pois a sala de aula ficava barulhenta no momento dos jogos e os alunos não relatavam as jogadas ou pensamentos, havendo assim pouco material para análise. Além disso, os gravadores chamavam a atenção dos alunos, sendo que em um dos grupos este foi desligado. Assim, ficou decidido que não haveria mais este registro nas demais aulas, sendo substituído pelo registro de vídeo, alternando entre os grupos de estudantes no momento dos jogos.

No dia 04 de maio ocorreu a terceira aula, com a presença de 12 alunos. Incialmente foi planejado que nas três últimas aulas seria utilizado apenas as versões pequenas dos jogos, jogados em grupo, mas, como citado anteriormente, percebeu-se a necessidade de repassar as regras em todas as aulas. Desta forma, iniciou-se a aula em rodinha com um jogo grande e jogando meninos contra meninas. Após relembrar as regras e de algumas partidas com os alunos, foram distribuídos os jogos dos grupos. Já nesta aula percebeu-se um desenvolvimento dos alunos quanto ao jogo, pois estavam jogando com mais segurança. 
Porém, eles ainda necessitavam de mediação para jogar e da confirmação do resultado do jogo pela professora. Nesta aula, durante o momento em grupo, a aluna Sara não quis jogar quando chegou sua vez, mas voltou quando foram distribuídos os jogos pequenos.

Ficou claro que para que o jogo alcançasse os objetivos esperados era necessária a mediação da pesquisadora diariamente. Decidiu-se, então, que as aulas sempre seriam iniciadas com o jogo grande e com toda a turma para fazer a mediação, posteriormente seriam distribuídos os materiais menores para os grupos, estimulando assim a autonomia dos alunos. A mediação da pesquisadora era feita mais diretamente nos jogos com toda a turma, pois com os jogos em grupos de quatro alunos eram difícil de acompanhar a todos, sendo que os alunos a todo momento vinham para mostrar o resultado à pesquisadora, o que deixava a aula tumultuada.

Havia 14 alunos presentes no dia 7 de abril, quando foi ministrada a quarta aula. Repetiu-se a dinâmica das aulas anteriores: iniciando com o jogo grande e toda a turma para relembrar as regras e estratégias e disponibilizando os jogos pequenos e em grupos na segunda parte da aula. Já com os jogos com toda a turma foi possível perceber a evolução dos alunos. Eles já mostravam perceber a linha na diagonal e compreendiam a alternância entre os jogadores, sendo que eles mesmos indicavam de quem era a vez de jogar. Também nesta aula, notou-se que alguns alunos se destacavam dos demais e auxiliavam todo o grupo. Dentre os alunos que mais se destacavam estavam a Rafaela, o Matias e a Sandra. Estes eram capazes de prever o final do jogo. Em alguns momentos, mesmo faltando uma ou duas jogadas sabiam se iria empatar ou se era possível algum dos grupos vencer. Estes alunos indicavam onde os demais deviam jogar. A postura diante do jogo também mudou, os alunos se mostravam mais interessados, bem como mais concentrados.

Na última aula com o Jogo da Velha, ministrada no dia 12 de abril de 2016, com a presença de todos os alunos, a dinâmica do jogo com toda a turma foi modificada. Ao invés de alternar as jogadas entre meninos e meninas, foi escolhido a cada partida duas duplas que jogariam entre si. Enquanto as duplas jogavam os demais acompanhavam e torciam e os pontos eram computados. Nesta aula foi mais fácil perceber a evolução de cada aluno e de toda a turma com relação ao jogo. Os alunos pensavam mais em cada jogada, refletindo sobre onde deviam fazê-la e se poderiam ganhar ou atrapalhar os demais participantes. Nesta aula os alunos foram perguntados se queriam jogar com os as versões pequenas ou continuar com o grande e eles escolheram o grande, que foi jogado até o final da aula. 
A relação do jogo com o aluno Marcos, que apresenta necessidade educacionais especiais foi complicada devido a sua limitação física e cognitiva. Inicialmente tentou-se incluir o aluno nos grupos com os demais colegas, porém eles não tinham maturidade para lidar com um colega com tanta dificuldade para desenvolver e compreender o jogo. Quando estava com os grupos de colegas ele era deixado de lado e se cansava, saindo pela sala de aula e mexendo nos materiais disponíveis. Na terceira aula a pesquisadora tentou acompanhar o aluno durante o jogo, mas havia a necessidade de passar entre todos os grupos e as demais crianças frequentemente a chamavam para tirar uma dúvida ou mostrar e confirmar uma vitória, impedindo que ela focasse no aluno. Na quarta aula a pesquisadora pediu que a auxiliar acompanhasse o aluno, que foi a melhor forma de trabalhar o jogo com ele. A auxiliar podia dar toda a atenção ao aluno, que começou a se interessar mais pelas atividades propostas.

\subsubsection{Jogo da Memória}

A experiência das aulas anteriores foi utilizada para desenvolver o Jogo da Memória com os alunos. Ficou definido que todos os dias seriam iniciados com a versão grande com toda a turma para relembrar as regras e dar oportunidade aos alunos com mais dificuldade de compreender bem o jogo.

A maior parte da turma já tinha jogado ou já conhecia o jogo proposto, o que não interferiu na empolgação deles. Quando o material foi apresentado, ainda na caixa surpresa, os alunos ficaram ansiosos para descobrir qual seria a atividade e, após revelado, ficaram satisfeitos e apresentaram vontade de jogar.

O Jogo da Memória pode ser jogado por mais de dois participantes, mas, para configurar como Jogo de Reflexão Pura, houve o cuidado de estabelecer novamente duas equipes para jogar quando estava toda a turma e os jogos menores eram desenvolvidos em duplas.

Na primeira aula com o Jogo da Memória, este e suas regras foram apresentados aos alunos em versão grande. Esta aula ocorreu dia 19 de abril de 2016 e haviam 13 alunos presente. Os alunos se sentaram em rodinha, já se dividindo nas equipes: meninos contra meninas. Após explorar o material e suas regras, foi explicado aos alunos a necessidade de ficar atentos às cartas, memorizando os pares para 'r quando iniciasse o jogo. Nesta aula, 
foram realizadas rodada com cada aluno jogando individualmente apenas para fixar as regras. Ao final desta partida, os alunos que conseguiram conquistar alguma carta, deveriam contalas para que os demais comparassem as quantidades e estabelecessem o vencedor. $\mathrm{Na}$ primeira partida todos os alunos conseguiram jogar e houve a necessidade de repetir quase metade da turma para concluir. Iniciou-se uma nova rodada, seguindo as mesmas características, mas neste momento o jogo encerrou com apenas metade da turma tendo oportunidade de participar, demonstrando a facilidade com que os alunos compreenderam a atividade proposta e se apropriaram dela.

Em seguida, foram separados os times, meninos e meninas. Os times eram alternados e os alunos revezavam as jogadas, juntando ao final todas as cartas conquistadas por cada time e realizando a contagem para estabelecer qual equipe era a vencedora. Nesta aula foram realizadas 5 partidas com as equipes, e os alunos já cobraram os jogos para usar em duplas.

Foi possível perceber no desenvolvimento deste jogo que os alunos já estavam mais habituados à sequência das jogadas e esperavam sua vez de jogar. Também compreenderam com mais facilidade a dinâmica e as regras da atividade, sendo que quase todos os alunos jogavam da forma correta, virando apenas duas cartas em cada momento e jogando novamente apenas quando encontravam um par. Apenas os alunos Mônica e Marcelo apresentaram dificuldade em compreender esta dinâmica. Mônica tentava olhar as cartas antes de virar, levantando um pouco do chão para olhar por baixo. Marcelo queria virar as cartas até encontrar o par correto.

A segunda aula, ministrada dia 26 de abril de 2016 com todos os 14 alunos presentes, também foi iniciada com o jogo em tamanho grande e uma disputa entre meninos e meninas. Houve um intervalo maior entre a primeira e a segunda aula deste jogo pois nesta semana houve um feriado, 21 de abril. Já na primeira partida ficou evidente a evolução dos alunos. A aluna Mônica, que na primeira aula buscava olhar os desenhos das cartas, nesta aula era a que mais conseguia se lembrar dos lugares dos pares, virando mais cartas corretas e, inclusive, auxiliando os demais colegas. Os demais alunos também se mostraram mais atentos, de modo que os jogos finalizavam mais rapidamente. Nesta aula, todos os alunos foram capazes de, em algum momento, encontrar um par correto, demonstrando seu desenvolvimento.

Após algumas rodadas com toda a turma, foi distribuído o jogo e versão menor para os alunos interagiram em grupo. O jogo para toda a turma era composto por 20 cartas, formando 10 pares diferentes, já a versão menor tinha a metade, 10 cartas que formavam 5 pares 
distintos. Os alunos não tiveram dificuldade em jogar, mesmo sem a intervenção da pesquisadora.

No dia 28 de abril de 2016, com a presença de apenas 10 alunos, o Jogo da Memória foi retomado para a terceira aula. Como definido, a aula iniciou com a versão grande do jogo, desenvolvida com toda a turma. Foram realizadas 5 partidas. No restante da aula os alunos jogaram em duplas com os jogos pequenos. Observando os alunos jogando, foi possível perceber que algumas duplas o aluno, ao distribuir as cartas, deixava os pares juntos, e vencia com facilidade. Os alunos foram reunidos novamente na rodinha para que fosse estabelecida mais uma regra. Ficou acordado com os estudantes que quem distribuísse as cartas seria o último a jogar. Esta regra foi suficiente para sanar o problema e os alunos jogaram corretamente até o final da aula.

A quarta aula foi ministrada para 13 alunos no dia 03 de maio de 2016. Após iniciar com o jogo com toda a turma, jogando apenas três partidas, os alunos foram novamente divididos em duplas para interagir com a versão pequena. A pesquisadora, neste momento, decidiu modificar a dinâmica da aula e chamar cada dupla para jogar individualmente, podendo, assim, observar como os alunos estavam lidando com o material. Com esta dinâmica foi possível perceber que os alunos haviam realmente compreendido o jogo, pois o estavam desenvolvendo corretamente. Havia alunos com mais facilidade, que conseguiam se lembrar do posicionamento de até 3 pares e eventualmente acertavam os demais, finalizando o jogo com apenas uma rodada, porém mesmo os alunos que apresentavam mais dificuldade eram capazes de acertar pelo menos um par em sua primeira jogada.

Dia 05 de maio de 2016 foi realizada a aula de encerramento do Jogo da Memória. Neste momento estavam presentes 13 alunos. Nesta aula, a pesquisadora questionou aos alunos se eles gostariam de jogar em duplas ou se preferiam permanecer durante toda a aula jogando toda a turma em duas equipes. Os alunos, unanimamente, optaram por jogar com toda a turma. Aparentemente, o jogo em tamanho grande era um material mais atraente aos alunos. Desta forma, na última aula com o Jogo da Memória não houve jogo em duplas, e foi possível realizar 10 partidas com toda a turma, finalizando com um empate entre as equipes que foi comemorado por toda a turma. 


\subsubsection{Cara a Cara}

A troca de jogos foi realizada, mas manteve-se a proposta para as aulas, assim, a primeira aula iniciou com a apresentação do jogo em versão grande para os alunos. O Cara a Cara se desenvolve em um tabuleiro que, para que todos os alunos pudessem ver sem dificuldade, foi fixado no quadro branco. Assim, para prosseguir com a aula, foi solicitado aos alunos que trouxessem suas cadeiras para frente, ao invés de se sentarem no chão. Esta aula ocorreu dia 17 de maio de 2016 e estavam presentes 11 alunos. Dentre os alunos, nenhum conhecia o jogo proposto e todos ficaram empolgados quando viram o material, além de ansiosos por sua vez de jogar.

Da mesma forma que as demais aulas, a turma foi dividida em duas equipes para jogar, permanecendo a divisão meninos e meninas para facilitar a identificação destas. Após apresentar aos alunos o jogo e suas regras, foi realizada a primeira partida. As regras do jogo foram apresentadas em partes. Inicialmente os alunos jogaram apenas com um tabuleiro, sendo que o original é realizado com um tabuleiro para cada jogador, e ao invés de os alunos fazerem perguntas, a pesquisadora apresentou as dicas para descobrirem o personagem. $\mathrm{Na}$ primeira partida foram apresentadas as dicas alternando as equipes, e a cada dica os alunos tinha oportunidade de descartar os personagens e dar um palpite. Neste primeiro momento os alunos não compreenderam que deveriam descartar os personagens sempre que era dada uma dica, e, ao invés de proceder desta forma, e davam palpites aleatórios antes do descarte. $\mathrm{O}$ jogo foi repetido selecionando um personagem para cada equipe e pedindo que os alunos não dessem mais os palpites, apenas descartassem, e venceriam quando deixasse apenas uma opção de personagem.

O jogo foi repetido novamente, porém desta vez já solicitando que os alunos fizessem as perguntas. Antes de iniciar o jogo, a pesquisadora elaborou com o auxílio dos alunos uma lista de questões que podiam ser feitas. A pesquisadora iniciou a lista sugerindo as questões "é menino?", “é menina?” e "tem o cabelo amarelo?”. Os alunos puderam então propor suas questões. A aluna Rafaela sugeriu a questão "tem cabelo marrom?”, o aluno Diego propôs “tem sapato preto?”, a aluna Sandra indicou "usa chapéu?” e o aluno Marcelo colocou a questão "tem asa?".

Apesar da lista de questões, durante o jogo os alunos permaneciam com os palpites, de modo que na partida seguinte sempre que um aluno sugeria um personagem a pesquisadora 
solicitava que trocasse a sugestão por uma pergunta. Desta forma, mesmo que com dificuldade, os alunos passaram a utilizar as questões, mas ainda não tinham autonomia para criar outras.

A segunda aula, ministrada para 13 alunos no dia 19 de maio de 2016, foi iniciada novamente com todos os alunos sentados em cadeiras. Nesta aula houve problema com a filmagem, a câmera parou de filmar sozinha, sendo registrado apenas 3 minutos e 24 segundos da aula.

Para iniciar o jogo, foi instituída uma nova regra ao jogo, os alunos não podiam dizer os nomes dos personagens durante as perguntas. Desta forma os alunos eram estimulados a criar e utilizar as perguntas. Inicialmente os alunos utilizavam as perguntas já estabelecidas, que foram relembradas no início da aula, mas eventualmente apareceram perguntas diferentes. A crianças propunham perguntas se baseando em um personagem específico, por exemplo, ao invés de perguntar "é o palhaço?", os alunos questionavam “tem nariz vermelho?". Nesta aula ainda não foi introduzido o jogo em duplas, pois os alunos ainda necessitavam de intervenção para desenvolver o jogo.

$\mathrm{Na}$ aula seguinte, ainda com os alunos sentados nas cadeiras, retomamos as regras e as perguntas e iniciamos o jogo. Esta aula ocorreu dia 24 de maio de 2016 e estavam presentes 12 alunos. A primeira partida ocorreu com a pesquisadora escolhendo o personagem e com a turma dividida em duas equipes e, mesmo relembrando as perguntas os alunos voltavam a sugerir personagens específicos. Quando isso ocorria a pesquisadora solicitava que fizesse outra pergunta e relembrava da regra de não dizer os nomes dos personagens. $O$ primeiro jogo ficou entre o anjo e a fada. O aluno Matias perguntou "tem cabelo escuro?" e a Rafaela "tem asas?", perguntas que não excluíam nenhum dos personagens. Então o aluno Marcelo questionou "é menino?", e encerrou o jogo, mas ainda utilizando as questões inicialmente propostas.

O jogo foi realizado mais uma vez, sendo que sobraram os personagens policial e bombeiro. A pesquisadora solicitou que os alunos observassem os personagens restantes e criassem uma pergunta para encerrar o jogo. Depois de algumas tentativas, o aluno Diego perguntou “é vermelho?", vencendo o jogo com uma pergunta criada por ele.

Como os alunos estavam ansiosos para jogar em duplas, foram apresentadas e entregues as versões pequenas. Observando os jogos, foi possível perceber que os alunos 
buscavam fazer as perguntas propostas e criar novas, além de corrigir os colegas que falavam o nome dos personagens.

A quarta aula foi realizada dia 03 de maio de 2016 e haviam 13 alunos em sala. Esta foi iniciada, como as demais, com os alunos sentados nas cadeiras e com o jogo em tamanho grande, disputando meninos e meninas. Porém, a dinâmica foi modificada, sendo a aula dividida em dois momentos. No primeiro momento, a pesquisadora solicitou que os alunos escolhesses os personagens e desafiassem a equipe adversária. Foi selecionado um aluno de cada vez, alternando as equipes. Neste momento, os alunos conseguiram utilizar as questões e criar suas próprias, além de respeitar as jogadas da equipe adversária. Após 5 jogadas de cada equipe, e verificando o desenvolvimento dos alunos com relação ao jogo, a pesquisadora decidiu integrar uma nova regra ao jogo, propondo que os alunos jogassem com dois tabuleiros simultaneamente. Para tal, a pesquisadora chamou um aluno de cada equipe e pediu que se sentassem em uma mesa à frente da turma, orientando-os como proceder com os dois tabuleiros. Após três jogadas, os alunos foram liberados em duplas para jogar com dois tabuleiros, o que procedeu até o final da aula. Os alunos foram capazes de assimilar esta nova regra sem grandes dificuldades, conseguindo alternar as jogadas e realizar as perguntas. Apenas uma dupla, as alunas Mônica e Sandra, apresentaram dificuldade com a dinâmica e decidiram jogar como anteriormente, apenas com um tabuleiro, alternando as jogadas.

Com 13 alunos em sala foi ministrada a última aula, no dia 05 de maio de 2016. Nesta a pesquisadora iniciou como usualmente, com uma competição com toda a turma e, após 5 partidas, havia sido planejada a troca para os jogos em duplas. Porém, os alunos solicitaram que a partida continuasse entre equipes, o que foi atendido. Assim, na última aula com o Cara a Cara foi utilizado apenas a versão grande do jogo, competindo meninos contra meninas, sendo possível que cada aluno escolhesse um personagem e conduzisse a competição.

\subsubsection{Mancala}

O jogo foi introduzido aos alunos contando sua origem, no dia 7 de junho de 2016 com 12 alunos presentes. Nenhum aluno conhecia o jogo, e todos tiveram dificuldade de aprender e lembrar do nome. Como se trata de um jogo complexo, a pesquisadora decidiu na primeira aula apresentar apenas suas regras básicas: a configuração inicial, como o jogo 
deveria ser movimentado, como seria finalizado e quem seria o vencedor. As demais regras deveriam ser adicionadas quando os alunos dominassem as propostas.

Com os alunos em roda foram explicadas as regras e iniciou-se o jogo, assim como os demais, com os alunos sentados em rodinha e alternando quem iriam jogar. No primeiro jogo os alunos formaram um time para jogar contra a pesquisadora. Foi utilizado um jogo com 12 covas e 4 sementes em cada para iniciar as aulas com o Mancala.

Quando o jogo foi apresentado os alunos ficaram empolgados para jogar, porém este se estendeu muito e os alunos foram mostrando desinteresse. Ao final do jogo os alunos não estavam mais interessados em saber quem foi o vencedor ou quanto ficou o jogo, além de algumas crianças já terem saído da rodinha. Na primeira aula não foi possível repetir o jogo por causa do tempo tomado e do desinteresse dos alunos. Também ficou claro que apenas esta jogada não foi suficiente para os alunos compreenderem o jogo.

Por causa da dificuldade dos alunos, ficou decidido que, para as aulas seguintes, o jogo deveria ser reduzido.

Na segunda aula, que ocorreu dia 9 de junho de 2016 com 11 alunos presentes, o jogo utilizado tinha 6 cavas com 3 sementes em cada. A aula foi introduzida com a turma toda, alternando os alunos nas jogadas. Foram desenvolvidas 3 partidas e, como os alunos estavam ansiosos para jogar nas duplas, a pesquisadora distribuiu o jogo e as sementes.

Já no primeiro contato com os alunos ficou claro que eles ainda não haviam entendido totalmente o jogo, pois não colocavam a quantidade certa de sementes nas casas e pareciam não saber o sentindo da distribuição destas. Os alunos distribuíam as sementes aleatoriamente. A maior parte das duplas entregou o jogo antes do fim da aula e não quis mais jogar. Então, os jogos foram recolhidos e foi solicitado aos alunos que se sentassem novamente em rodinha, onde eles foram questionados se queriam este jogo novamente. Apenas dois alunos quiseram jogar de novo, os alunos Iara e Sérgio.

Assim, como ficou claro que o jogo não tinha despertado o interesse dos alunos, sendo decidido muda-lo na aula seguinte.

\subsubsection{Pontinhos}

O jogo Pontinhos foi selecionado para substituir o Mancala, visto que os alunos não haviam demonstrado interesse neste. Como seria iniciado um novo jogo, a pesquisadora 
decidiu não continuar as 5 aulas propostas para o Mancala, mas sim iniciar novamente a contagem das aulas, o que aumentou a previsão de aulas de 20 para 22. A professora concordou prontamente com o proposto.

A pesquisadora solicitou que os alunos se sentassem em suas cadeiras no centro da sala, considerando, a partir das experiências anteriores, que assim eles ficariam mais confortáveis do que sentados no chão. O tabuleiro do jogo foi fixado no quadro branco.

O jogo foi introduzido com um tabuleiro de $4 \times 4$, sendo apresentadas suas regras. A primeira partida foi realizada entre a pesquisadora e um aluno selecionado, o aluno Sérgio, demonstrando as jogadas e características do Pontinhos. Já na segunda partida iniciou-se a competição, como nas aulas anteriores, entre meninos e meninas. Por este ser um jogo mais curto, foi possível realizá-lo diversas e vezes, escolhendo um aluno de cada equipe para jogar de cada vez e computando os pontos. Foi possível realizar sete partidas, contando com a participação de todos os alunos. Como o Pontinhos é um jogo mais dinâmico e os alunos já apresentavam mais facilidade com o desenvolvimento dos jogos, os alunos foram capazes de compreender suas regras com facilidade. Esta aula foi ministrada dia 14 de junho de 2016 e haviam 12 alunos presentes.

Com o desenvolvimento deste jogo foi possível perceber a evolução dos alunos tanto cognitiva, pois aprenderam um jogo novo com mais facilidade do que anteriormente, quanto no comportamento, pois os alunos conduziam as jogadas e a vitória era comemorada sem provocações e a derrota aceita com mais tranquilidade.

Na segunda aula, dia 16 de junho de 2016, haviam 10 alunos presentes. Prosseguiu-se o jogo com o tabuleiro de $4 \times 4$, que foi trabalhado com os alunos sentados nas cadeiras até que uma das equipes fizesse 3 pontos. Após a vitória dos meninos, a pesquisadora apresentou aos alunos o jogo em versão menor para jogar, deixando que os alunos escolhessem e formassem as duplas. Depois de observar as crianças jogando, a pesquisadora notou que os alunos sempre seguiam a mesma sequência de jogadas, além de não estar observando se estavam desenhando a terceira linha para que o próximo jogador fechasse o quadrado. Assim, sempre quem começava o jogo perdia a partida, sendo que o outro fechava todos os quadrados. A pesquisadora, então, chamou os alunos à frente de novo e explorou as jogadas e estratégias para o jogo, pedindo que os alunos observassem onde jogar com mais atenção e buscassem jogar longe das linhas já desenhadas. Os alunos voltaram a jogar em duplas e apresentaram um avanço, diversificando as jogadas. 
A terceira aula ocorreu dia 21 de junho de 2016 com 13 alunos presentes. A aula foi iniciada reforçando o jogo 4x4 antes de introduzir uma versão maior do tabuleiro, o jogo de 5x5. A transição dos jogos foi tranquila, de modo que nenhum aluno apresentou dificuldade, além de demonstrarem preferência pelo jogo com mais quadrados. Nesta aula os alunos Diego, Rafaela e Sérgio foram capazes de antecipar o resultado do jogo ainda faltando algumas jogadas. Em uma partida, faltando ainda 3 linhas a serem preenchidas o aluno Diego disse "eita, a Sandra vai ganhar", prevendo as possíveis jogadas e contando os quadros já preenchidos. A aluna Rafaela, observando o colega Yago pensar sobre a jogada quando havia apenas um quadrado a ser formado disse para ele "tanto faz você riscar aqui ou ali, de qualquer jeito eu vou fechar o quadrado". O aluno Samuel percebendo que dos 16 quadrados possíveis a sua equipe já tinha marcado 9, já comemorou a vitória antes de finalizar o jogo. Após as jogadas entre equipes os alunos prosseguiram para o jogo em duplas, podendo escolher se jogariam com o tabuleiro $4 \times 4$ ou $5 \times 5$.

No dia 22 de junho de 2016, na quarta aula, ministrada para 10 alunos, foi repetido o processo das demais, o jogo em equipes com o tabuleiro de $5 \times 5$ até que uma das equipes completasse 3 pontos. Foi, então, distribuído o jogo para duplas. Os alunos não apresentaram dificuldade de jogar, porém o aluno Diego e a aluna Mônica não respeitavam os limites da linha, riscando mais do que uma aresta do quadrado de cada vez. Após a observação e orientação da pesquisadora os alunos passaram a jogar corretamente.

O jogo Pontinhos foi encerrado dia 23 de junho de 2016 com 13 alunos em sala. Os alunos pediram para não jogar a versão grande do jogo, para que eles pudessem passar a aula com a versão menor, o que foi aceito pela pesquisadora, que se limitou a observar as jogadas dos alunos. Ficou claro que os alunos estavam prestando mais atenção ao jogo e pensavam mais antes de jogar para não deixar o outro jogador vencer.

\section{6 Última aula}

A última aula foi ministrada no dia 28 de junho com a presença de 12 alunos. Esta aula não estava programada inicialmente, mas após trabalhar os jogos com os alunos, ficou clara a necessidade de um momento de conclusão da pesquisa. Assim, apesar de terem sido planejadas 20 aulas, foram ministradas 23 . 
Nesta aula, todos os jogos foram disponibilizados aos alunos, que puderam escolher quais gostariam de jogar e trocar quantas vezes quisessem. Os jogos foram apresentados novamente e os alunos se dividiram em duplas para jogar. Uma dupla, os alunos Marcelo e Sérgio, jogaram com todos os disponíveis, as demais duplas escolheram 2 ou 3 jogos. Dentre os jogos, o mais escolhido foi o Pontinhos, escolhido por seis das sete duplas. O jogo Cara a Cara foi escolhido cinco vezes, o Jogo da Memória, o Jogo da Velha e o Mancala foram escolhidos três vezes. Ao entregar os jogos os alunos queriam brincar com a versão grande e se mostravam desapontados ao receber as versões menores.

Observando os alunos jogando, foi possível perceber que, mesmo na última aula, ainda existiam crianças que não haviam desenvolvido completamente a postura diante do jogo. $\mathrm{O}$ aluno Diego não jogava seguindo as regras, tentando jogar duas vezes seguidas ou mudar a jogada para ganhar. Este fato deixou os alunos que formavam duplas com ele chateados e reclamaram do comportamento do colega. A pesquisadora interviu conversando com o aluno, buscando fazê-lo perceber que esta não era uma forma justa de jogar. O aluno se mostrou resistente às orientações da pesquisadora, mas percebeu que só teria a companhia dos colegas se concordasse em jogar de acordo com as regras, o que ele fez ao se juntar com outra criança.

Ao final da aula, foi solicitado aos alunos que desenhassem o jogo que mais gostaram de jogar. A pesquisadora entregou às crianças uma folha de papel em branco e lápis de cor para que desenhassem livremente, solicitando apenas que registrassem seus nomes. Cinco alunos desenharam o Cara a Cara, quatro fizeram o desenho do Jogo da Memória, três registraram o jogo Pontinhos e um aluno reproduziu o Jogo da Velha. Nenhum dos alunos desenhou o Mancala. O desenho do aluno Marcos não foi computado pois não foi possível compreender o que ele tinha desenhado.

A seguir, pode-se observar algumas representações dos jogos produzidas pelas crianças por meio do desenho livre. No momento do desenho os alunos não estavam observando os jogos, portanto se apoiaram apenas na memória para produzí-lo. Apesar disso, pode-se notar a riqueza dos detalhes presentes nos desenhos, o que expressa que os alunos foram capazes de assimilar os jogos propostos, demosntrando que estar foram atividades significativas para eles.

Observa-se, por exemplo, no desenho da aluna Rafaela (Figura 14) a representação de alguns personagens do Cara a Cara, sendo possível identificar a fada e o anjo, além de verificar que a disposição das cartas está similar à proposta pelo jogo. A aluna Sandra (Figura 
15), também foi capaz de reproduzir esta disposição, além de representar os personagens do jogo. Apesar de serem semelhantes no desenho, demonstram a relação que a aluna criou com o jogo, visto que ela teve o cuidado de representar apenas figuras humanas, sendo o mesmo apresentado no jogo.

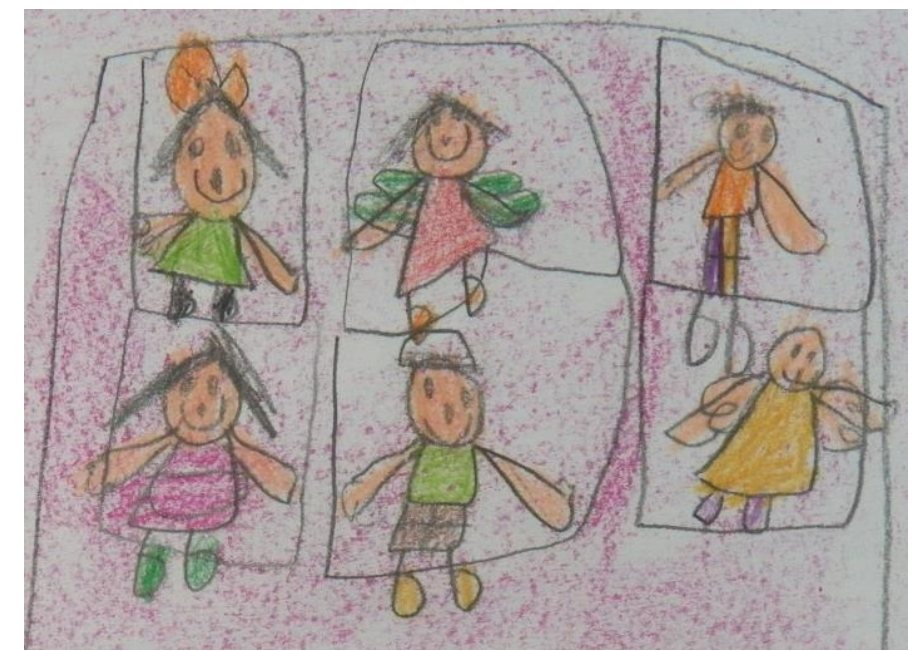

Figura 14: Desenho do jogo Cara a Cara feito pela aluna Rafaela.

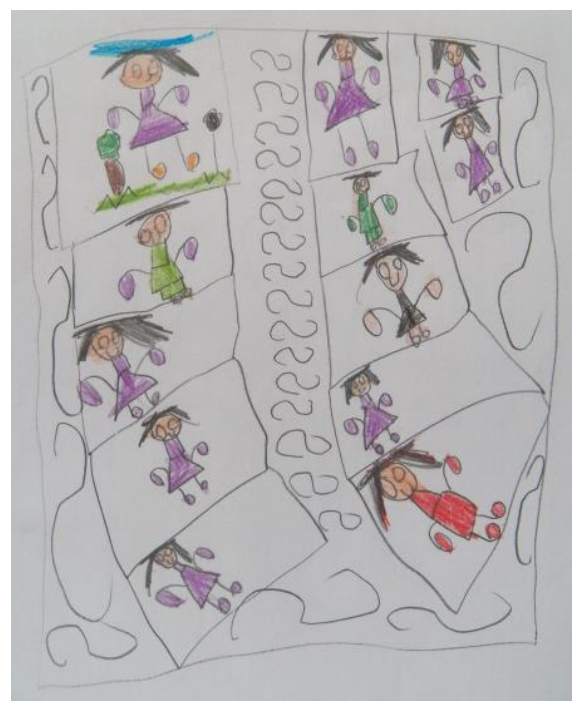

Figura 15: Desenho do jogo Cara a Cara feito pela aluna Sandra.

A representação do Jogo da Memória produzida pela aluna Mônica (Figura 16) traz os pares das cartas espalhadas pela folha, o que representa a disposição destas no jogo. Além de ter o cuidado de representar as figuras similares inclusive na cor, a aluna também registrou corretamente a quantidade de cartas do jogo individual: cinco pares. Vale ressaltar que esta foi a aluna que mais demonstrou dificuldade com o primeiro momento com o Jogo da Memória, mas ao final escolheu este como seu jogo preferido, demonstrando que, mesmo os desafios 
propostos resultam em momentos de ludicidade. O aluno Sérgio (Figura 17), apesar de não desenhar as imagens em pares, foi capaz de reproduziu corretamente a disposição e o formato das cartas, além de registrar algumas imagens que este continha, como a maçã, o carro e o relógio, e até mesmo registrar o nome de uma das figuras, característica de um dos jogos apresentados aos alunos.

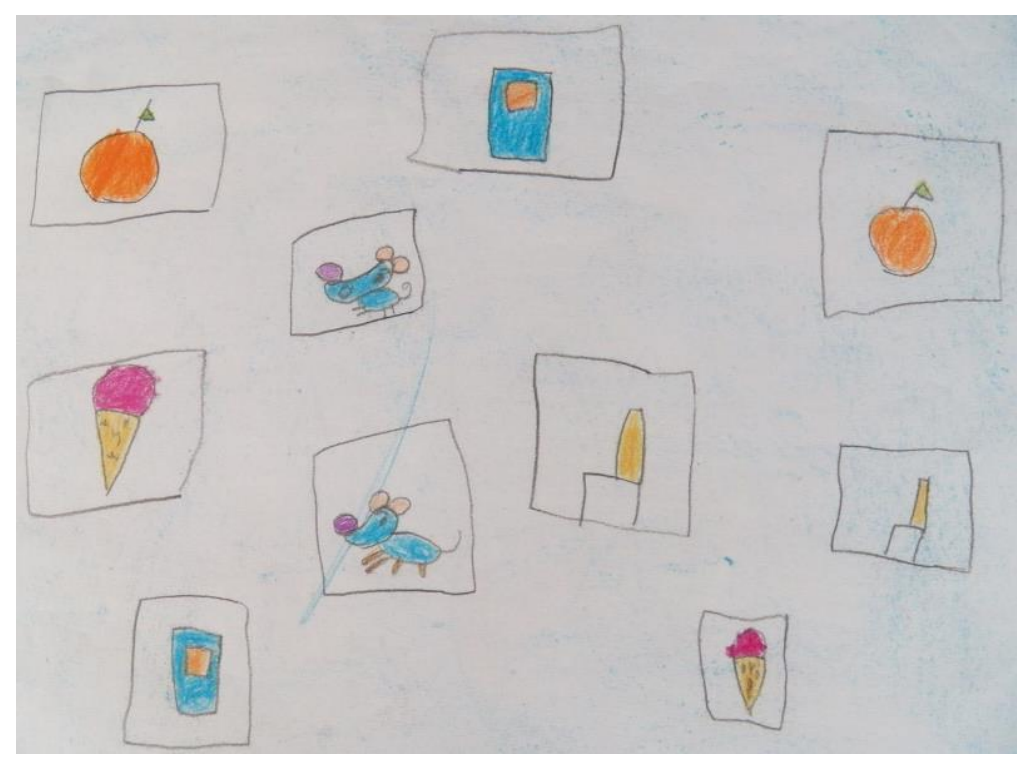

Figura 16: Desenho do Jogo da Memória feito pela aluna Mônica.

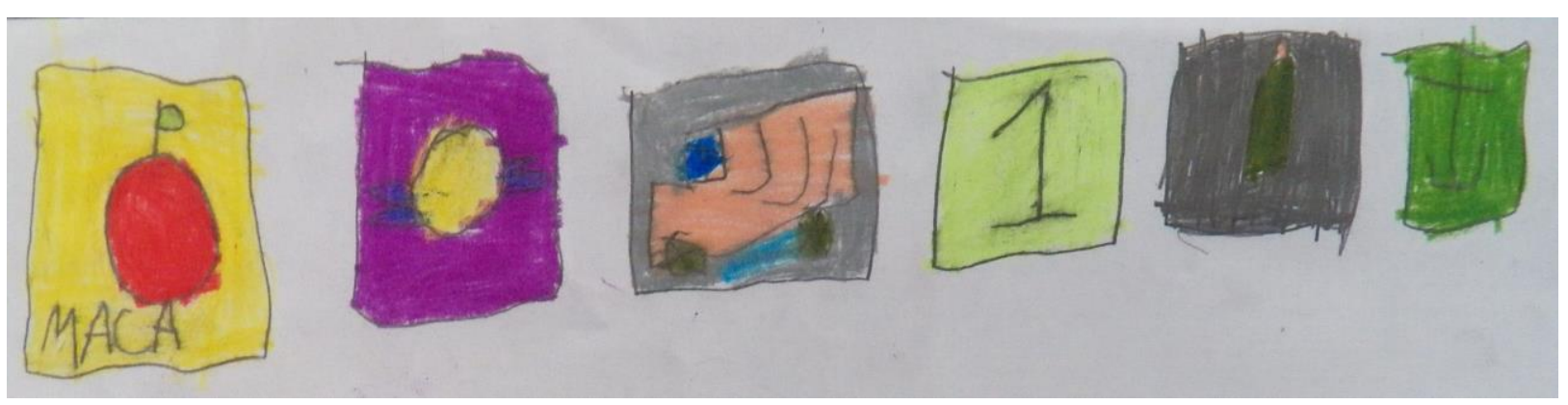

Figura 17: Desenho do Jogo da Memória feito pelo aluno Sérgio.

O jogo Pontinhos foi fielmente representado pelo aluno Davi (Figura 18), que inseriu inclusive as linhas vermelhas que eram traçadas pelos alunos. Tanto ele quanto a aluna Iara (Figura 19) foram capazes de registrar o formato do jogo através da disposição dos pontos. A aluna Iara não só representou o formato, mas também a quantidade correta de Pontinhos. Nota-se também, no desenho da Iara, as duas crianças jogando, sendo que uma delas está com o pincel na mão, representando a forma de jogar. 


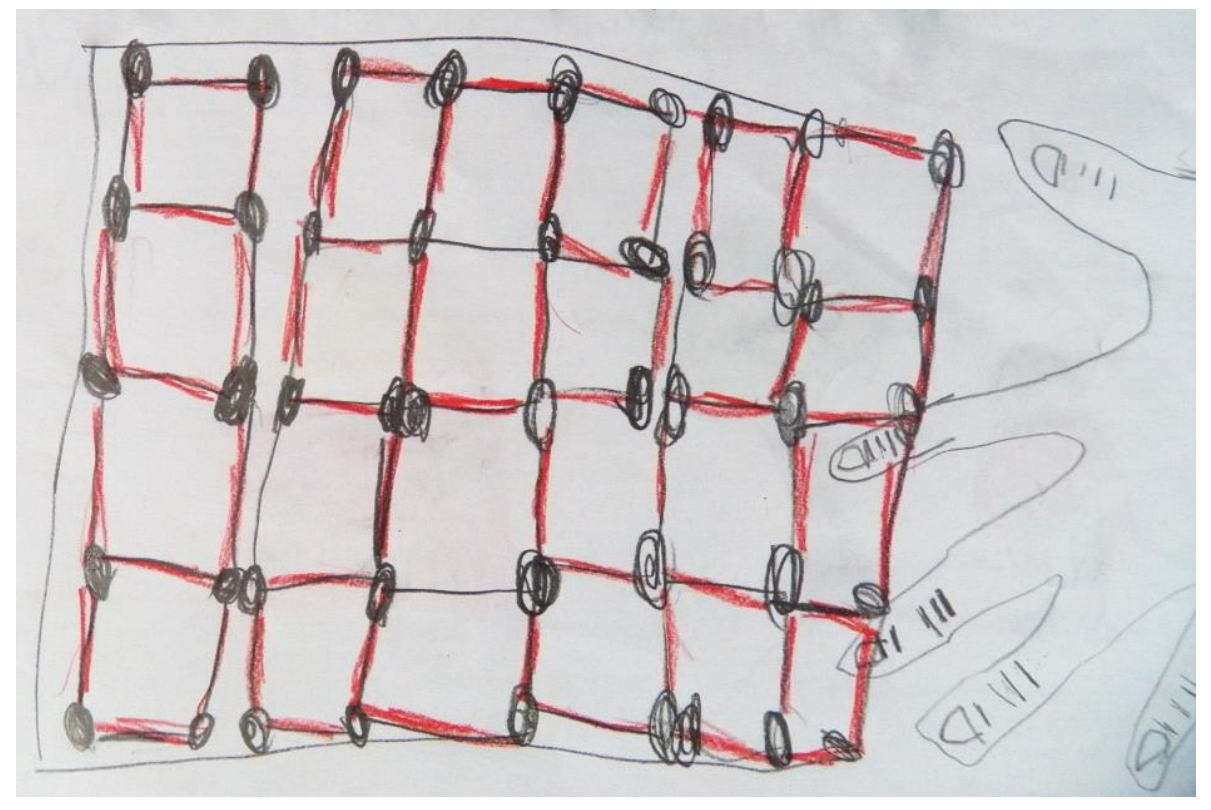

Figura 18: Desenho do jogo Pontinhos feito pelo aluno Davi.

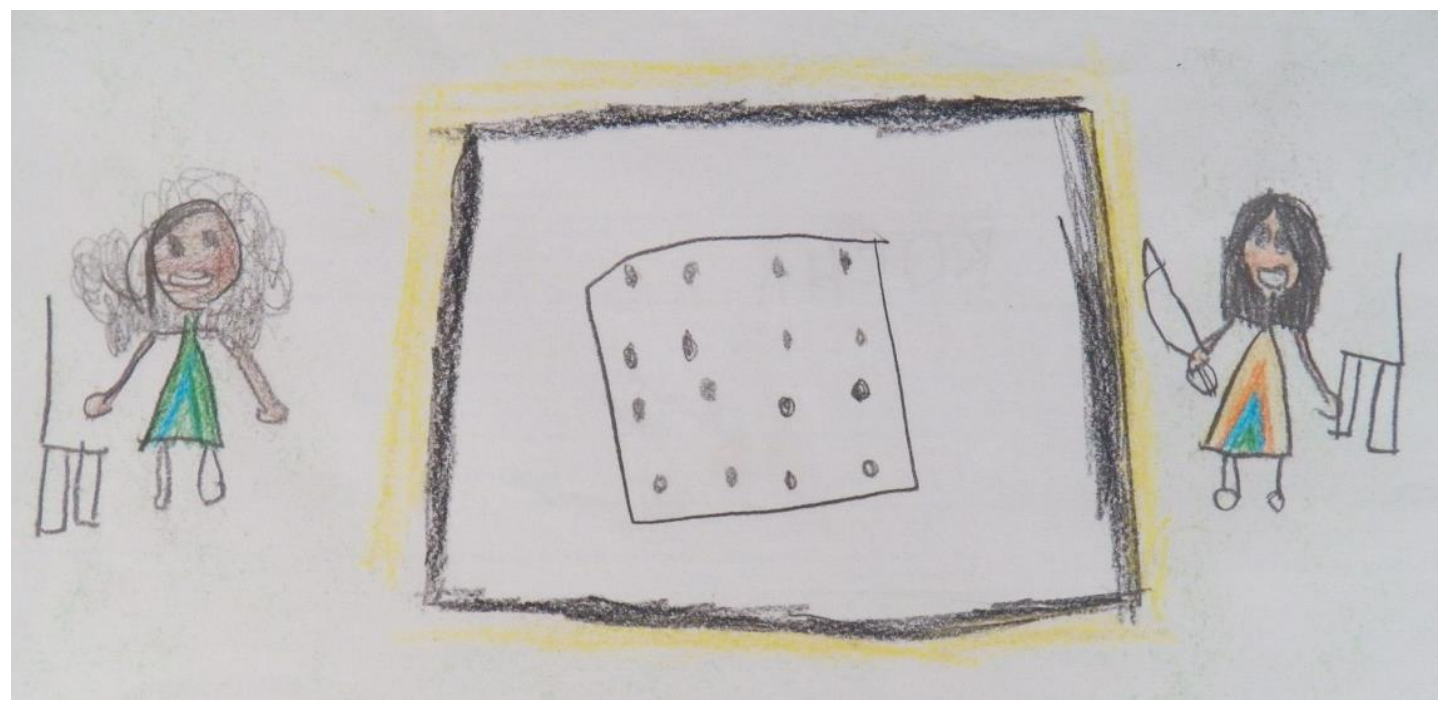

Figura 19: Desenho do jogo Pontinhos feito pela aluna lara.

Ao final da aula foi possível montar um ranking com a preferência dos alunos, computados da seguinte forma:

1. Cara a Cara -5 escolhas, 4 desenhos.

2. Pontinhos -6 escolhas, 3 desenhos.

3. Jogo da Memória - 3 escolhas, 4 desenhos.

4. Jogo da Velha - 3 escolhas, 1 desenho.

5. Mancala -3 escolhas, nenhum desenho. 
Para concluir a aula e o projeto foi solicitado aos alunos que se sentassem em rodinha. Junto com a pesquisadora, os alunos conversaram sobre as aulas. Eles relataram ter gostado das aulas e disseram que gostariam que houvessem mais jogos. $\mathrm{O}$ aluno Diego relatou que o mais legal era quando os meninos ganhavam das meninas, demonstrando o poder que a competição tem de estimular o jogo. Quando questionados, nenhum aluno percebeu que os jogos tinham relação com a matemática, relataram não estarem estudando, mas sim brincando.

\subsection{Avaliação final}

A avaliação final foi realizada individualmente com cada estudante, repetindo-se as atividades desenvolvidas antes do início do projeto: avaliação de competências e dificuldades conceituais sobre número do grupo CIMETE, um quebra-cabeças e uma imagem para encontrar figuras escondidas. Esta avaliação foi realizada três meses depois da inicial, sendo atrasado com relação ao planejamento inicial para se adequar às demandas da escola.

Este procedimento foi realizado nos dias 30 de junho e 05 e 27 de julho de 2016 . No primeiro dia foram atendidas nove crianças, sendo todas as que estavam presentes na escola no momento. No segundo encontro foram realizadas avaliações com mais três crianças, porém havia um aluno, o Matias, que esteve afastado da escola por um logo período, sendo necessário esperar ele retornar para realizar a avaliação. Ele foi o único aluno avaliado no último dia. O referido aluno também não esteve presente na aplicação dos dois últimos jogos, o Mancala e o Pontinhos.

A avaliação foi realizada em uma sala disponível na escola e a professora escolheu a ordem em que os alunos seriam avaliados, sendo que cada momento demorou cerca de 15 minutos e todos foram registrados em vídeo. Como todo o projeto foi registrado em vídeo, os alunos não se incomodaram com a presença da câmera.

Apesar de os alunos já terem tido contato com os procedimentos realizados, apenas dois demonstraram se lembrar do material. O aluno Diego reconheceu o material logo no início da sessão e o aluno Marcelo reconheceu o quebra-cabeças, adiantando a questão que seria feita com este.

Mesmo já tendo tido contato com a pesquisadora e a câmera durante o decorrer de toda a pesquisa, alguns alunos aparentavam timidez no início da avaliação, o que não 
interferiu no processo, visto que o contato com o material proposto deixava os alunos mais à vontade.

\subsection{Entrevista com a professora}

A entrevista com a professora ocorreu após o horário normal da aula, para que a professora pudesse responder às questões com tranquilidade. Foi realizada na sala de aula, quando os alunos já haviam sido dispensados, estando apenas a professora e a pesquisadora em sala. A entrevista foi registrada em áudio, e foram feitas anotações apenas posteriormente. Seu objetivo foi levantar as impressões da professora acerca da pesquisa proposta, sendo uma atividade de curta duração.

A professora se mostrou disponível para participar da entrevista, sendo um momento agradável de troca de informações. Ela apenas solicitou que não fosse utilizada a filmadora, sendo a entrevista registrada apenas em áudio.

No decorrer da conversa houve apenas uma interrupção de uma outra professora que precisava falar com a professora da turma antes de sair da escola, o que não atrapalhou o andamento da atividade.

A entrevista seguiu o roteiro proposto anteriormente (APÊNDICE E), mas não se reteve a este, havendo alterações e complementos de perguntas quando necessário. Este momento fluiu bem e a professora foi capaz de expressar suas impressões e observações acerca da proposta da pesquisa e da reação e desenvolvimento dos alunos. 


\section{LUDICIDADE E HABILIDADES}

As informações em que se baseia esta pesquisa foram construídas no decorrer do primeiro semestre letivo do ano de 2016 por meio da aplicação de jogos e sua observação, da avaliação individual dos alunos e de uma entrevista com a professora regente da classe escolhida.

Todos os momentos foram registrados em áudio ou vídeo, o que auxiliou a análise, possibilitando à pesquisadora reviver os momentos trabalhados, podendo assim perceber novos detalhes e aspectos. Todo o registro realizado foi visto e revisto pela pesquisadora, o diário de bordo produzido foi analisado e reestruturado e a entrevista com professora foi transcrita para melhor análise.

Neste ponto do trabalho é essencial retomar os objetivos que o norteiam, utilizando-os para não perder o foco. São objetivos específicos deste trabalho:

1. Aplicar Jogos de Reflexão Pura em uma sala de aula de educação infantil.

2. Analisar se o uso de Jogos de Reflexão Pura desperta o espírito lúdico dos alunos.

3. Verificar como o uso de Jogos de Reflexão Pura interfere na aprendizagem, e em especial na aprendizagem matemática.

4. Identificar as estruturas matemáticas estimuladas a partir dos Jogos de Reflexão Pura. Partindo-se dos objetivos anteriormente propostos, serão analisadas as informações produzidas no decorrer da aplicação prática desta pesquisa. Para esquematizar a análise dos dados, esta será dividida em três etapas:

1. Aplicação dos jogos: neste tópico serão analisadas as ações, falas e atitudes dos alunos provocadas pelos jogos aplicados em sala e sua ligação com a aprendizagem e, em especial, com a matemática, além de verificar a aplicação lúdica dos Jogos de Reflexão Pura para a educação infantil e conferir se cada jogo estimulou as estruturas matemáticas esperadas.

2. Avaliações individuais: aqui serão relatados os dados coletados com a avalição inicial e comparados com os resultados da avaliação final, verificando se houve desenvolvimento dos alunos com relação aos aspectos avaliados. Também se retoma o aspecto da ludicidade, uma vez que o objetivo das atividades propostas era manter o espírito lúdico inclusive no momento da avaliação. 
3. Entrevista com a professora: este item exporá as considerações da professora acerca da pesquisa realizada e tecerá uma análise sobre estas.

É importante salientar que no decorrer da pesquisa os dados foram sendo analisados para fundamentar as etapas posteriores. Assim, a cada aula era analisada a funcionalidade do planejamento proposto, verificando possíveis mudanças para a melhoria deste.

\subsection{Aplicação dos jogos}

Esta análise se baseia nos conceitos e estruturas que esperava-se desenvolver com o uso dos Jogos de Reflexão Pura, destacando em que momentos foi possível perceber este desenvolvimento.

Há muitos outros aspectos que podem ser desenvolvidos com o uso dos jogos, porém, para esta análise focou-se no proposto pelos objetivos específicos. Como relatado anteriormente, com os jogos propostos esperava-se desenvolver a reflexão, a atenção, a discriminação visual, a estratégia, o pensamento lógico, a linguagem, a memória, a associação, o pareamento e a contagem. Cada jogo proposto trabalhava diversos aspectos concomitantemente. Além dos aspectos relacionados, o trabalho com os jogos tinha o objetivo de contribuir para o desenvolvimento do conceito de número e de estruturas matemáticas: correspondência, comparação, classificação, sequenciação, seriação, inclusão e conservação (LORENZATO, 2011).

Acredita-se que todos estes elementos, tanto as habilidades quanto as estruturas, influenciariam na aprendizagem matemática dos alunos.

Além dos pontos já relacionados, verificou-se também por meio da pesquisa o aspecto lúdico presente nos Jogos de Reflexão Pura, constatando se seria aplicável à educação infantil.

\subsubsection{Ludicidade}

Um ponto central desta pesquisa é fornecer materiais lúdicos para trabalhar com a educação infantil. Assim, é necessário analisar se os Jogos de Reflexão Pura podem ser considerados desta forma. Como exposto anteriormente, para este trabalho a ludicidade foi percebida como algo subjetivo, que está presente na relação do indivíduo com o outro, com 
um objeto ou com uma atividade. Quando esta relação é prazerosa, feita e repetida de maneira espontânea esta é considerada lúdica.

Assim, o fato de se trabalhar com jogos não é suficiente para afirmar que a pesquisa propôs atividades lúdicas, é necessário observar a relação do aluno com os elementos apresentado.

A pesquisadora foi recebida pelos alunos com muito entusiasmo, o que se manteve no decorrer de toda a pesquisa. Já na avaliação inicial foi possível perceber o gosto que as crianças demonstravam pelos elementos utilizados. O uso dos recursos na avaliação deixou os alunos que demonstravam timidez mais à vontade, ficando clara a vontade deles de interagir com a atividade proposta, como foi o caso da aluna S. que só interagiu com a pesquisadora ao ver os animais de pelúcia. Além disto, os alunos relatavam aos outros que tinham gostado da atividade, e conduziam os colegas ao local da avaliação com empolgação. A aluna Vanessa, ao conduzir o colega Diego para a sala onde ocorria a avaliação disse para ele "é bem legal, você vai gostar" e o aluno Yago relatou para a professora que ele havia apenas brincado com a pesquisadora. $\mathrm{O}$ fato de as crianças terem se divertido com a avaliação também ficou claro pela vontade da repetição. O aluno Sérgio ao sair da sala perguntou "quando eu posso vir de novo?", e no segundo dia de avaliação os alunos já avaliados pediram para repetir a atividade.

A mesma relação era percebida ao se tratar dos jogos. Quando a pesquisadora apresentava os jogos aos alunos, nenhum deles reclamava de ter que sentar na rodinha ou demorava. A proposta inicial era deixar os alunos a vontade para interagir com os jogos e em poucos momentos ou alunos se recusaram a fazê-lo. Na maioria das aulas as crianças discutiam para ser o primeiro jogador e reclamavam quando a pesquisadora pedia para recolher os materiais.

Os alunos demonstraram uma boa relação com os jogos individuais também, sendo que sempre que um jogo era anunciado os alunos cobravam a versão reduzida e gostavam de jogar com os colegas. Apesar disto, é possível observar a preferência pelas versões maiores dos jogos, visto que em três das quatro aplicações, na última aula os alunos escolheram permanecer interagindo com estas do que jogar com as versões pequenas.

$\mathrm{Na}$ última aula fica claro o gosto dos alunos pelos jogos, sendo que todos jogaram mais de uma vez e pediram que a aula prosseguisse quando a pesquisadora a estava encerrando. 
A volta da pesquisadora para realizar a avaliação do aluno Matias também demonstra a ludicidade das atividades propostas, pois os demais alunos comemoraram quando a pesquisadora chegou e cobraram a continuação dos jogos, mesmo ela já havendo explicado que a pesquisa estava encerrada.

Porém, nem todas as atividades propostas demonstraram despertar o espírito lúdico dos alunos. O jogo Mancala não conseguiu prender a atenção dos alunos, que deixaram o jogo de lado antes do fim das duas aulas em que este foi utilizado. Acredita-se que o jogo não alcançado o objetivo proposto por ser mais complexo, podendo estar além da compreensão dos alunos da faixa etária trabalhada.

Também houveram momentos em que os alunos se recusaram a continuar jogando, porém em 23 alunas ministradas, isto ocorreu apenas em duas ocasiões distintas e com dois alunos, a aluna Sandra e o aluno Diego. Ambos os alunos retomaram o jogo no mesmo dia.

Com base nas observações das relações dos alunos com os jogos propostos e suas reações, fica claro que os Jogos de Reflexão Pura foram capazes de despertar o espírito lúdico nos alunos do $2^{\circ}$ período da educação infantil. Os alunos não foram obrigados a jogar pela pesquisadora, mas todos se mostraram ansiosos para o início das aulas e houveram poucas incidências de alunos que se recusaram a participar, demonstrando a espontaneidade, essencial para os jogos e para a ludicidade. O prazer pela repetição também é percebido, pois os alunos jogavam repetidas vezes e em diversos momentos pediam para a aula prosseguir.

\subsubsection{Habilidades}

Esta pesquisa considera que com os Jogos de Reflexão Pura é possível desenvolver diferentes habilidades importantes para a aprendizagem e, em especial, para a aprendizagem matemática. Serão apresentadas a seguir evidencias que demonstrem o desenvolvimento das habilidades em questão no decorrer das aulas ministradas por meio do uso dos jogos.

\subsubsection{Pensamento lógico}

O pensamento lógico é claro no desenvolvimento dos jogos. Como já explicitado, o pensamento lógico é entendido por essa pesquisa como a análise dos dados para chegar a uma conclusão. 
Tal habilidade é percebida inicialmente quando os alunos decidiam onde ou como realizariam a jogada com base na situação do jogo no momento. Os alunos precisavam observar as jogadas já realizadas pelo oponente para decidir onde deveriam fazê-la. Nas primeiras partidas estas eram realizadas de forma aleatória, o que não configura pensamento lógico, porém as jogadas evoluíam com o desenvolvimento das aulas, de modo que diversas vezes os alunos trocavam a posição de suas peças antes de encerrar um movimento ou pensavam por um tempo antes de jogar. Em alguns momentos os alunos foram capazes de antecipar as jogadas a partir da observação do jogo. Em uma partida de Jogo da Velha a aluna Rafaela, ao observar o jogo, sugeriu para a aluna Mônica "se você jogar aqui você pode jogar aqui ou aqui que ganha na próxima". Também observando o jogo Pontinhos, o aluno Sérgio foi capaz de perceber quem seria o vencedor três jogadas antes do término do jogo. O aluno disse aos demais colegas, "não adianta mais jogar, as meninas ganharam".

Os alunos também necessitavam refletir sobre as jogadas para ganhar o jogo ou evitar perdê-lo. No Jogo da Velha os alunos observavam a possibilidade de "atrapalhar" as jogadas do adversário para impedi-lo de vencer. Para tomar esta decisão era necessário o uso do pensamento lógico.

Por fim, para compreender a alternância entre os jogadores proposta pela pesquisadora, os alunos também utilizavam o pensamento lógico. Inicialmente as crianças não compreendiam a alternância entre as equipes e entre os participantes de uma mesma equipe querendo jogar mais de uma vez, porém com o desenvolvimento das aulas os alunos passaram a perceber quem seria o próximo jogador.

\subsubsection{Reflexão}

A reflexão, compreendida nesta pesquisa como pensar sobre um fato ou atividade, também é muito estimulada pelo uso dos jogos.

Esta habilidade aparece inicialmente relacionada ao pensamento lógico, visto que para tal é necessário refletir sobre os dados apresentados. Assim, a reflexão fica evidente quando os alunos param a jogada para pensar onde seria melhor fazê-lo, como é o caso do aluno Yago, que sempre que iria realizar uma jogada parava o jogo para decidir onde seria melhor. O aluno Sérgio, ao jogar o jogo Pontinhos, mais de uma vez decidiu trocar a sua jogada por ter selecionado um lugar mais adequado. 
No jogo Cara a Cara a reflexão também fica clara quando os alunos criam as perguntas para descobrir qual é o personagem selecionado pelo colega. As crianças precisavam refletir sobre os personagens dispostos para criar uma questão, habilidade que também evoluiu com as aulas, sendo que nos primeiros momentos com os jogos os alunos apenas indicavam um personagem ou utilizavam perguntas sugeridas pela pesquisadora. No decorrer das aulas eles passaram a criar suas próprias questões.

\subsubsection{Atenção}

Fica claro o desenvolvimento da atenção dos alunos quando se observa seu comportamento com relação aos jogos no decorrer da pesquisa. Inicialmente os alunos eram agitados e não conseguiam se acalmar para ouvir a explicação. Conforme as aulas passaram os alunos se demonstraram cada vez menos agitados e atentos à fala da professora para compreender as regras propostas.

Os alunos também se demonstraram mais atentos enquanto jogavam com seus parceiros com os jogos individuais. Nas primeiras aulas a pesquisadora foi muito requisitada pelas crianças, o que não ocorria mais ao final da pesquisa, pois os alunos não estavam mais conversando tanto, dispensando maior atenção ao lidar com o jogo.

\subsubsection{Discriminação visual}

Esta habilidade tem seu desenvolvimento identificado com mais clareza no Jogo da Memória, uma vez que para formar os pares os alunos necessitam reconhecer as imagens dispostas. O jogo Cara a Cara também exige a discriminação visual para analisar detalhes dos personagens para criação de uma pergunta ou exclusão de um componente com base na resposta do adversário.

O desenvolvimento desta habilidade foi claramente percebido com relação ao Jogo da Velha. No início da aplicação deste jogo os alunos não percebiam a formação da linha na diagonal. Após o desenvolvimento das aulas as crianças já se mostravam capazes de identificá-las, percebendo qual era a equipe vencedora e sendo capazes inclusive de atrapalhar a outra equipe na formação desta. Na primeira aula, com o jogo em equipes, duas vezes a linha em diagonal foi formada e os alunos relataram que o jogo havia empatado, já na quarta 
aula o aluno Sérgio formou a linha diagonal com uma jogada e comemorou a vitória. Na quinta e última aula a aluna Rafaela percebeu a vitória do time das meninas com uma linha diagonal antes mesmo da pesquisadora.

O jogo Pontinho também exige a discriminação visual para a formação dos quadrados e para não deixar possibilidade de o outro formar o quadrado, o que também apresentou desenvolvimento com o decorrer das aulas. Na segunda aula com o referido jogo, quando os alunos foram apresentados aos jogos individuais os alunos jogavam sempre seguindo uma mesma sequência. Após a intervenção da pesquisadora os alunos passaram a alternar a jogada de modo a não deixar os quadrados para o oponente fechar.

\subsubsection{Estratégia}

A estratégia pode se configurar como um conceito complexo para a educação infantil, mas pode ser percebido quando as crianças tomavam decisões conscientes para vencer os jogos.

No Jogo da Velha os alunos faziam jogadas para atrapalhar o adversário a vencer, o impedindo de completar a linha. A criação de perguntas para o jogo Cara a Cara também se constitui como uma estratégia, já que os alunos precisavam criar as questões para excluir personagens específicos.

Outras atitudes dos alunos também demonstram o desenvolvimento da estratégia. Ao jogar Cara a Cara ou Jogo da Memória os alunos davam palpites quando os demais jogavam. Quando era um membro da sua equipe eles indicavam a resposta correta, já se fosse membro da equipe adversária, as crianças demonstravam respostas incorretas. Também ao lidar com o Jogo da Memória em versão reduzida algumas crianças ao distribuírem as peças o faziam de modo que facilitasse a localização, dispondo os pares lado a lado. Apesar de estas atitudes não estarem diretamente relacionadas ao desenvolvimento das regras do jogo, foram maneiras que os alunos encontraram de provocar a sua vitória ou de seu time, configurando uma forma de estratégia. Tais atitudes não foram encorajadas pela pesquisadora, pois vão de encontro ao comportamento que se espera com relação ao jogo, mas demonstram a capacidade de os alunos de criarem estratégias conscientes para vencer. 


\subsubsection{Memória}

A memória é claramente mais presente no Jogo da Memória, sendo fácil perceber o desenvolvimento dos alunos neste. Na primeira partida jogando com toda a turma, quase todos os alunos jogaram mais de uma vez. Já na segunda partida não foi possível todos os alunos jogarem, pois, os alunos foram capazes de encontrar os pares com mais facilidade. É importante considerar que já na segunda aula todos os alunos foram capazes de encontrar algum par durante o jogo, demonstrando assim o seu desenvolvimento.

Além do referido jogo, a memória também é trabalhada e desenvolvida através das regras do jogo, sendo que os alunos aprendem as regras e são capazes de replicá-las e até de ensiná-las aos demais colegas. Na segunda aula com o Jogo da Velha, já com a versão menor, o aluno Matias, que estava jogando com uma aluna que havia faltado na primeira aula, relatou para a pesquisadora "tia, a Mônica não sabia jogar, eu tive que ensinar para ela", demonstrando que ele havia apreendido as regras do jogo e que tinha a capacidade de retomálas para ensinar a colega.

\subsubsection{Associação}

A associação é trabalhada especialmente pelo Jogo da Memória e pelo Cara a Cara, tendo em vista a necessidade de distinguir e comparar as imagens do primeiro e de reconhecer características dos personagens do segundo. Desta forma, o desenvolvimento dos alunos quanto à identificação dos pares do Jogo da Memória, bem como na criação de perguntas e capacidade de exclusão de personagens com base nas respostas obtidas, demonstra a evolução deles com relação à associação.

\subsubsection{Pareamento}

O pareamento foi desenvolvido em dois momentos. Com mais clareza é possível percebê-lo no Jogo da Memória, pois a dinâmica do jogo já exige a formação dos pares de imagens semelhantes. Porém, esta habilidade foi trabalhada com mais frequência na aplicação dos jogos em versão menor, quando os alunos necessitavam de formavam duplas para jogar, compondo um pareamento entre os estudantes. 


\subsubsection{Contagem}

Esta habilidade não estava incluída no foco inicial da pesquisa, que buscava desenvolver jogos e atividades sem focar o desenvolvimento de conteúdos matemáticos, mas sim focando em desenvolver habilidades para a aprendizagem matemática. Porém, a contagem foi amplamente trabalhada no decorrer das aulas.

Pode-se notar este desenvolvimento através da contagem das cartas ganhas no Jogo da Memória e dos pontos feitos no jogo Pontinhos. A distribuição das sementes no jogo Mancala, bem como a contagem das sementes coletadas ao final, também estimula esta habilidade, apesar de este jogo não ter sido trabalhado por muitas aulas.

Por fim, a contagem esteve presente em todas as aulas, quando os pontos das equipes ou dos jogadores eram computados.

\subsubsection{Linguagem}

No decorrer das aulas também foi possível perceber o desenvolvimento da linguagem. Os alunos tinham novos vocabulários estimulados pelo jogo, pois aprendiam, além dos nomes destes, palavras relacionadas à sua execução, desenvolvidas a partir da explicação das regras no início de cada aula.

O jogo que mais estimulou a linguagem foi o Cara a Cara, já que os alunos deveriam criar questões com base em características dos personagens disponíveis. Nesta atividade foi possível perceber a evolução, visto que os alunos criavam as perguntas com mais facilidade nas últimas aulas em comparação com as primeiras.

A capacidade de transmitir as regras do jogo a outro colega também estimula o desenvolvimento da linguagem. Como já relatado, em alguns momentos houve a necessidade de um aluno ensinar o outro a jogar, o que eles faziam sem dificuldades.

\subsubsection{Estruturas matemáticas}

A partir da aplicação dos jogos com os alunos, pode-se perceber, além do desenvolvimento de habilidades, também o trabalho com estruturas matemáticas. Lorenzato 
(2011) elenca sete estruturas matemáticas percebidas na educação infantil: correspondência, comparação, classificação, sequenciação, seriação, inclusão e conservação. Destes, cinco foram notados pela pesquisadora no decorrer desta pesquisa.

A correspondência, definida como a percepção da relação um a um, como já exposto, é claramente notada no Jogo da Memória, onde cada carta tem o seu par, mas também pode ser percebida na formação de pares para jogar, pois cada aluno precisa do seu parceiro. Além destes momentos, ela pode ser percebida na distribuição dos materiais, como por exemplo um tabuleiro para cada dupla ou um pincel para cada jogador. Também quando se pensa em equipes há a presença da correspondência, pois há uma forma de sinalização para cada equipe, no Jogo da Velha, por exemplo, são utilizados os sapos e joaninhas, e no jogo Pontinhos, as letras identificando cada jogador.

A comparação pode ser exercitada através da comparação dos pontos marcados pelas equipes ou participantes durante os jogos, estabelecendo assim o vencedor de cada dia. Esta também era utilizada em alguns jogos para definir o vencedor de cada partida. No Jogo da Memória, quando ao final os alunos comparavam a quantidade de cartas coletadas. O Mancala também exigia a contagem das sementes e comparação para estabelecer o vencedor. No jogo Pontinhos, assim como os demais, os alunos comparavam os pontos ganhos, marcados com suas letras, para determinar o vencedor.

Em todos os jogos mencionados, a comparação poderia ser baseada na contagem ou apenas com base na percepção visual. No jogo de memória, em alguns casos os alunos comparavam a altura dos montinhos de cartas coletados. Já no Mancala e no Pontinhos, em algumas partidas a diferença de pontuação era tão grande que podia ser percebida com clareza. Na terceira aula do jogo Pontinhos a aluna Alice, jogando com sua dupla, ao final do jogo levou o tabuleiro para a pesquisadora para mostrar que este estava "com muitos quadradinhos vermelhos e poucos azuis", percebendo assim a sua vitória, já que nesta partida ela estava utilizando um pincel vermelho e sua colega um azul.

Como a comparação também pode ser definida como a capacidade de reconhecer semelhanças e diferenças, tal habilidade também é bastante presente no Jogo da Memória, onde há a necessidade de comparar as imagens para definir se formam ou não um par, e no jogo Cara a Cara, onde os personagens são comparados com a informação adquirida, sendo eliminados quando há divergência ou mantidos identificando a semelhança. Pode-se considerar que no jogo Cara a Cara o aluno precisa comparar as imagens de que ele dispõe 
com uma escolhida pelo seu adversário sem ter acesso a esta, sendo tal ação amparada pelas perguntas criadas.

A classificação foi percebida para além da aplicação dos jogos, uma vez que a divisão da turma em equipes já configura uma forma de classificação, pois foi realizada seguindo um critério pré-estabelecido selecionado pelos alunos, a divisão entre meninos e meninas. Esta habilidade também foi desenvolvida por meio de alguns jogos, como o Cara a Cara e o Pontinhos. No Cara a Cara a classificação era utilizada quando o aluno excluía os personagens a partir de um critério estabelecido por ele por meio de uma pergunta e confirmado ou refutado pela resposta do colega. No Pontinhos era possível perceber tal habilidade na divisão dos quadrados, já que estes eram marcados com letras que podiam ser escritas com a mesma cor, ou mesmo, em alguns casos, a partir de cores distintas. Posteriormente, ao contar os pontos, os alunos se pautavam nesta marcação para classificar os seus pontos e os pontos do seu adversário.

A sequenciação foi trabalhada no decorrer de toda a dinâmica da aula. Tal estrutura seria a capacidade de propor uma sucessão de um elemento a outro, sem se basear em uma ordem. Este trabalho era percebido na alternância entre os jogadores durante uma partida, onde os alunos se sucediam variando os times, mas esta sucessão era mutável, uma vez que dependia da presença das crianças ou de onde elas estariam sentadas. A sequência de ações para o desenvolvimento da aula ou do jogo também estimulam a sequenciação, já que os alunos compreendiam que para jogar com o jogo em duplas era necessário inicialmente interagir com toda a turma, além de haver uma sequência de ações para tornar o jogo possível.

Em muitos momentos a contagem foi requerida, como descrito no item anterior. Alguns destes contavam com a presenças de materiais concretos, levando os alunos a perceber a relação entre número e quantidade, podendo trabalhar e refletir sobre esta. Apesar de muitas vezes a diferença entre quantidade ser perceptível, os alunos eram estimulados a contar, como forma de confirmar a informação. Desta forma a conservação, que seria a percepção de que uma quantidade independe da organização do material, também foi trabalhada através dos jogos propostos. 


\subsubsection{Habilidades desenvolvidas por cada jogo}

A partir da aplicação dos jogos em sala com os alunos, foi possível perceber que as habilidades matemáticas trabalhadas. Inicialmente esperava-se que os jogos desenvolvessem as habilidades conforme listadas abaixo:

f) Jogo da Velha: pensamento lógico, reflexão, a atenção, a discriminação visual e a estratégia.

g) Jogo da Memória: memória, a associação, o pareamento, a discriminação visual, a contagem e o pensamento lógico e as estruturas matemáticas comparação e correspondência.

h) Cara a Cara: linguagem, a discriminação visual, a atenção e a classificação. Além disso, também estimula o pensamento lógico, a estratégia, a reflexão e a comparação.

i) Mancala: construção de estratégias e a contagem. Este também estimula a reflexão, a atenção e o pensamento lógico.

j) Pontinhos: construção de estratégias e a contagem, além de a reflexão, a atenção e o pensamento lógico.

Após a observação da interação dos alunos com os jogos, percebeu-se que cada jogo estimulou mais habilidades do que era esperado.

Assim como planejado, o pensamento lógico foi trabalhado por meio de todos os jogos, mas houveram outras habilidades desenvolvidas por todos os jogos que inicialmente imaginava-se que seriam trabalhadas apenas por alguns. Foi o caso da memória, contagem, reflexão, atenção e estratégia.

Ao analisar os jogos, acreditou-se que a memória era desenvolvida apenas através do Jogo da Memória. A contagem foi percebida no Jogo da Memória, Mancala e Pontinhos, e a possibilidade de estimular a reflexão, atenção e estratégia foi notada apenas nos jogos Jogo da Velha, Cara a Cara, Mancala, Pontinhos.

Porém, tais habilidades foram estimuladas em todos os jogos, algumas vezes pela proposta do jogo, mas em outros momentos foram trabalhadas pela dinâmica necessária para jogar. A necessidade de seguir as regras e repassá-las aos colegas estimulou a linguagem e a memória, e a contagem e comparação dos pontos ganhos em cada partida e ao final de cada aula trabalhou a contagem. Tal obrigação com as regras também exigiu dos alunos atenção e reflexão, além da criação de estratégias. 
Desta forma, todos os jogos provocaram um desenvolvimento maior do que o esperado, o que pode ser verificado no quadro a seguir.

\begin{tabular}{|c|c|c|}
\hline JOGO & $\begin{array}{l}\text { HABILIDADES } \\
\text { ESPERADAS }\end{array}$ & $\begin{array}{l}\text { HABILIDADES } \\
\text { ESTIMULADAS }\end{array}$ \\
\hline $\begin{array}{l}\text { Jogo da } \\
\text { Velha }\end{array}$ & $\begin{array}{c}\text { Reflexão, atenção, } \\
\text { discriminação visual, } \\
\text { pensamento lógico, estratégia. }\end{array}$ & $\begin{array}{l}\text { Pensamento lógico, reflexão, } \\
\text { atenção, discriminação visual, } \\
\text { estratégia, memória, contagem, } \\
\text { linguagem. }\end{array}$ \\
\hline $\begin{array}{l}\text { Jogo da } \\
\text { Memória }\end{array}$ & $\begin{array}{c}\text { Memória, associação, } \\
\text { pareamento, discriminação } \\
\text { visual, contagem, pensamento } \\
\text { lógico. }\end{array}$ & $\begin{array}{l}\text { Pensamento lógico, reflexão, } \\
\text { atenção, discriminação visual, } \\
\text { estratégia, memória, associação, } \\
\text { pareamento, contagem, linguagem. }\end{array}$ \\
\hline Cara a Cara & $\begin{array}{l}\text { Linguagem, discriminação } \\
\text { visual, atenção, classificação, } \\
\text { pensamento lógico, estratégia, } \\
\text { reflexão e comparação. }\end{array}$ & $\begin{array}{l}\text { Pensamento lógico, reflexão, } \\
\text { atenção, discriminação visual, } \\
\text { estratégia, memória, associação, } \\
\text { contagem, linguagem, linguagem. }\end{array}$ \\
\hline Mancala & $\begin{array}{l}\text { Estratégia, contagem, reflexão, } \\
\text { atenção e pensamento lógico. }\end{array}$ & $\begin{array}{l}\text { Pensamento lógico, reflexão, } \\
\text { atenção, estratégia, memória, } \\
\text { contagem, linguagem. }\end{array}$ \\
\hline Pontinhos & $\begin{array}{l}\text { Estratégia, contagem, reflexão, } \\
\text { atenção e pensamento lógico }\end{array}$ & $\begin{array}{l}\text { Pensamento lógico, reflexão, } \\
\text { atenção, discriminação visual, } \\
\text { estratégia, memória, contagem, } \\
\text { linguagem. }\end{array}$ \\
\hline
\end{tabular}

Quadro 7: Comparação das habilidades esperadas e estimuladas pelos jogos.

\subsection{Avaliações individuais}

Como já relatado nesta dissertação, as avaliações individuais foram aplicadas antes do início das aulas com os jogos e reaplicadas ao final, possibilitando assim a comparação dos resultados para verificar o desenvolvimento dos alunos no decorrer deste período. 
É importante salientar que houve um intervalo de três meses entre as aplicações e que apenas dois alunos demonstraram se recordar do material utilizado pela pesquisadora, sendo que o uso do mesmo material ao início e ao final não interferiu nas respostas dadas pelas crianças.

\subsubsection{Avaliações individuais iniciais}

A avaliação inicial foi realizada em três dias distintos e seguindo a ordem: Avaliação do conceito de número do grupo CIMETE, quebra-cabeças e imagem para encontrar figuras escondidas. Estes itens são descritos no capítulo 4 desta dissertação.

Após a aplicação e análise das anotações da pesquisadora e dos registros em vídeo, foi possível estabelecer os dados relacionados a seguir.

$\mathrm{Na}$ avaliação do conceito de número, foi solicitado aos alunos que descrevessem a situação proposta. Em geral os alunos diziam que havia bichos de pelúcia, relatando o nome dos animais e diziam que eles tinham recebido fichas. Posteriormente, foram realizadas duas questões. A primeira questionava qual dos animais tinha mais fichas. Esta foi respondida corretamente por todos os alunos, que não necessitaram de intervenção. A questão seguinte, que solicitava que os alunos deixassem todos os animais com a mesma quantidade de elementos, poderia ser respondida de duas maneiras, utilizando mais fichas disponibilizadas pela pesquisadora ou reorganizando aquelas que já estavam dispostas na mesa. Esta questão foi respondida corretamente por nove alunos, sendo que destes, três alunos conseguiram responde-la apenas de uma maneira e seis apresentaram duas respostas distintas. Cinco alunos não foram capazes de encontrar nenhuma solução para o desafio. Dentre os alunos, apenas cinco não necessitaram de intervenção da pesquisadora, que precisou mediar a questão para os demais nove alunos.

A atividade do quebra-cabeças era composta por um triângulo e um quadrado, sendo que haviam 3 soluções possíveis para o quadrado e duas para o triângulo. Na avaliação inicial todos os alunos conseguiram montar pelo menos uma das figuras. Sendo que um aluno montou apenas o quadrado uma vez. Dois alunos conseguiram montar a imagem inteira, mas apenas uma vez. Oito alunos montaram o quadrado duas vezes e o triângulo uma vez. Por fim, dois alunos montaram tanto o triângulo quanto o quadrado duas vezes. Os alunos levaram em média 20 segundos para encontrar a primeira solução. Os alunos não apresentaram dificuldade 
ao encontrar a primeira solução para o quebra-cabeça, apesar de poucos terem conseguido montar as partes novamente.

A última avaliação era feita utilizando uma imagem e solicitando que os alunos encontrassem seis figuras específicas. Dos 14 alunos, apenas três foram capazes de indicar corretamente todas as figuras solicitas. 10 alunos encontraram apenas 5 imagens, sendo que todos confundiram a mesma imagem. Um aluno indicou corretamente apenas três imagens. Os alunos levaram em média 38 segundos para indicar todas as imagens, certas ou erradas.

\subsubsection{Avaliações individuais finais}

A avaliação final seguiu a mesma sequência da inicial, começando com a avaliação do conceito de número. Foi possível perceber uma grande evolução dos alunos com a replicação das atividades.

$\mathrm{Na}$ avaliação do conceito de número, após os alunos descreverem a situação proposta, o que foi feito de maneira similar à avaliação inicial, foi proposta a primeira questão. Novamente todos os alunos foram capazes de identificar qual dos animais havia recebido mais fichas. Com relação à segunda questão, para deixar todos os bichos com a mesma quantidade de fichas, apenas um aluno não conseguiu responder corretamente, sendo que 13 alunos foram capazes de encontrar solução para o problema proposto. Destes, um encontrou apenas uma solução e 12 alunos encontraram duas soluções. Entre os 14 alunos, apenas três necessitaram de intervenção, sendo que os outros 11 responderam de maneira autônoma.

Com a repetição do quebra-cabeças, todos os alunos se demonstraram capazes de montar as duas partes, triângulo e quadrado, pelo menos uma vez e levaram em média 22 segundos para encontrar a primeira solução. Entre os 14 alunos, três montaram as duas partes apenas uma vez cada, oito encontraram a solução para o quadrado duas vezes e para o triângulo uma vez, um aluno montou as duas partes duas vezes e dois alunos montaram o triângulo duas vezes e o quadrado três, todas as opções possíveis.

A imagem foi apresentada novamente aos alunos, solicitando que encontrassem as seis figuras indicadas. Desta vez, todos os alunos conseguiram encontrar pelo menos cinco imagens, sendo que todos confundiram a mesma imagem da avaliação inicial. Oito alunos foram capazes de encontrar todas as imagens propostas. Os alunos levaram em média 37 segundos para indicar todas as imagens solicitadas, estando estas corretas ou não. 


\subsubsection{Dados comparativos das avaliações}

A partir da comparação entre os resultados da avaliação inicial e final foi possível perceber o crescimento e desenvolvimento dos alunos no período de aplicação desta pesquisa. Tal desenvolvimento reflete e confirma o que foi observado pela pesquisadora no decorrer das aulas ministradas com os jogos.

Com a avaliação do grupo CIMETE, esperava-se avaliar a evolução da formação do conceito de número. Percebe-se, comparando as avaliações individuais, que houve um desenvolvimento dos alunos com relação a esta evolução. A questão que solicitava que os alunos igualassem as quantidades de fichas distribuídas aos animais foi respondida corretamente por nove alunos na avaliação inicial, sendo que destes, três alunos só encontraram uma solução. Já na avaliação final, 13 alunos solucionaram o problema, e apenas um deste não encontrou duas soluções. A partir desta evolução, fica claro o crescimento da capacidade dos alunos de resolver problemas e lidar com números e quantidades. Também a quantidade de alunos que necessitaram de intervenção apresentou uma redução significativa, demonstrando um aumento da autonomia dos alunos.

Com relação ao quebra-cabeças, houve um acréscimo pequeno da avaliação inicial para a final. Considerando cada parte separadamente, o quadrado e o triangulo, e computando quantas vezes cada aluno conseguiu encontrar as peças que se encaixavam em cada parte, verifica-se especialmente que na avaliação final todos os alunos foram capazes de montar pelo menos duas partes, e dois alunos encontraram todas as soluções possíveis, sendo que na avaliação inicial um aluno só encontrou uma solução e nenhum aluno conseguiu as cinco soluções disponíveis. A variação de tempo foi pequena, porém os alunos demoraram mais a resolver a atividade na avaliação final, o que pode demonstrar uma maior reflexão dos alunos. Apesar de o crescimento mensurável nesta atividade ser modesto, demonstra o desenvolvimento dos alunos com relação ao seu raciocínio, reflexão, estratégia, e pensamento lógico, uma vez que é necessária a utilização destas habilidades para encontrar a solução de um problema ou desafio proposto.

A comparação entre a avaliação inicial e final com relação à atividade da imagem também demonstra um crescimento significativo dos alunos. Mais da metade dos alunos, oito entre 14, foram capazes de encontrar todas as imagens na avaliação final, sendo que apenas 
três haviam indicado todas corretamente na avaliação inicial. Nenhum aluno encontrou menos de 5 imagens na avaliação final. É importante considerar que a mesma imagem confundiu os alunos tanto na avaliação inicial quanto na final. Este resultado demonstra o desenvolvimento dos alunos com relação à atenção, a discriminação visual, a comparação e a orientação espacial.

Por fim, a análise dos resultados das avaliações individuais inicial e final confirmam o que foi percebido através da observação no decorrer da aplicação dos jogos, que houve desenvolvimento dos alunos com relação às habilidades mencionadas, o que contribui para a aprendizagem matemática.

\subsection{Entrevista com a professora}

A entrevista com a professora foi realizada para que a profissional que acompanha diariamente as crianças pudesse opinar a respeito da proposta da pesquisa e relatar desenvolvimentos e comportamentos que ela pode observar dos alunos. O relato é de grande importância, já que, estando em contato diretamente com os alunos por um tempo maior do que a pesquisadora tem possibilidade, e propondo aos alunos diversas atividades, ela conhece melhor seus alunos e pode observar com mais clareza seu desenvolvimento. Também foram feitas questões para conhecer a professora, seu perfil e opinião acerca dos materiais usados e conceitos trabalhados na pesquisa.

Vale destacar que a professora esteve presente em sala em todas as aulas. Apesar de não estar em evidencia, deixando que a pesquisadora conduzisse as aulas com liberdade, esteve disponível para auxiliar aos alunos quando necessário e para proporcionar o suporte necessário à pesquisa, tanto pessoal quanto material.

A entrevista, realizada em sala ao final do horário da aula e registrada em áudio, pode ser acompanhada através do quadro a seguir.

\begin{tabular}{|l|l|}
\hline \multicolumn{1}{|c|}{ QUESTÕES } & \multicolumn{1}{c|}{ RESPOSTAS } \\
\hline Qual é a sua idade? & Tenho 43 anos. \\
\hline $\begin{array}{l}\text { Você tem graduação em } \\
\text { pedagogia, certo? }\end{array}$ & Sim. \\
\hline E tem alguma pós-graduação? & Tenho, em psicopedagogia. \\
\hline
\end{tabular}




\begin{tabular}{|c|c|}
\hline Há quanto tempo você dá aulas? & Há 22 anos \\
\hline $\begin{array}{l}\text { E nesta escola, você está há } \\
\text { quanto tempo? }\end{array}$ & Já tem 9 anos que eu trabalho aqui. \\
\hline $\begin{array}{l}\text { Você tem o costume de usar } \\
\text { jogos em sala de aula? }\end{array}$ & $\begin{array}{l}\text { Sim, eu já utilizo jogos em sala de aula. Gosto de } \\
\text { utilizá-los para introduzir, fixar um conteúdo, ou } \\
\text { simplesmente por diversão, para que as crianças } \\
\text { sintam prazer em jogar. }\end{array}$ \\
\hline $\begin{array}{l}\text { E para ensinar matemática, você } \\
\text { já usou algum jogo? }\end{array}$ & $\begin{array}{l}\text { Já utilizei e ainda utilizo jogos em matemática, } \\
\text { acredito que jogando a criança desenvolve a } \\
\text { capacidade de raciocínio e contração e com isso } \\
\text { há melhor desenvolvimento tanto em matemática, } \\
\text { quanto nas outras disciplinas. }\end{array}$ \\
\hline Ótimo, que jogos você utiliza? & $\begin{array}{l}\text { Uso quebra-cabeças, Jogo da Velha, Jogo da } \\
\text { Memória, jogo dos erros, entre outros. }\end{array}$ \\
\hline $\begin{array}{l}\text { Você acha que o uso de jogos } \\
\text { em sala de aula importante para } \\
\text { educação infantil? }\end{array}$ & $\begin{array}{l}\text { Acho muito importante, pois assim, as crianças } \\
\text { desenvolvem-se socialmente, aprendem a dividir, } \\
\text { a competir, entre outros pontos já citados na } \\
\text { questão anterior. }\end{array}$ \\
\hline $\begin{array}{lrr}\text { No decorrer das aulas os alunos } \\
\text { comentaram sobre } & \text { os } & \text { jogos } \\
\text { desenvolvidos } & \text { com } & \text { a } \\
\text { pesquisadora? } & \text { Como } & \text { eles } \\
\text { reagiram? } & & \end{array}$ & $\begin{array}{l}\text { Durante as aulas, as crianças comentaram sobre os } \\
\text { jogos e aguardavam ansiosas a chegada da } \\
\text { pesquisadora. Elas reagiram de maneira positiva, } \\
\text { amavam os dias em que aconteciam os jogos. Foi } \\
\text { uma experiência prazerosa. }\end{array}$ \\
\hline $\begin{array}{l}\text { Eu queira saber agora sua } \\
\text { opinião sobre alguns aspectos do } \\
\text { desenvolvimento dos alunos } \\
\text { sobre a pesquisa. Você notou } \\
\text { desenvolvimento deles quanto à } \\
\text { socialização? }\end{array}$ & $\begin{array}{l}\text { Sim, notei que os alunos se tornaram mais amigos } \\
\text { e solidários. Aprenderam a competir e se tornaram } \\
\text { mais independentes. }\end{array}$ \\
\hline $\begin{array}{l}\text { E em relação ao raciocínio e à } \\
\text { aprendizagem? }\end{array}$ & $\begin{array}{l}\text { Com os jogos, eles estão conseguindo se } \\
\text { concentrar melhor, chegando à um melhor } \\
\text { desempenho nas atividades. }\end{array}$ \\
\hline
\end{tabular}




\begin{tabular}{|l|l|}
\hline E a matemática, você notou & $\begin{array}{l}\text { Sim, percebo que eles estão mais independentes, } \\
\text { buscando vários caminhos para chegar às soluções }\end{array}$ \\
desenvolvimento dos alunos & $\begin{array}{l}\text { das atividades, estão resolvendo seus conflitos e } \\
\text { neste aspecto? }\end{array}$ \\
situações problema de maneira independente.
\end{tabular}

Quadro 7: Questionário aplicado à professora.

Inicialmente percebe-se tratar de uma profissional experiente, não apenas na profissão que exerce, mas também na escola onde está atualmente. A professora em questão acompanhou esta mesma turma no ano anterior, quando ainda cursavam o $1^{\circ}$ período. Também apresenta boa formação, buscando dar continuidade aos seus estudos por meio de uma pós-graduação.

A professora reconhece a importância e necessidade da utilização de jogos em sala de aula, especialmente para a educação infantil, e relata utilizar os jogos para o ensino da matemática. Ao solicitar que dissesse alguns jogos com os quais já havia trabalhado, a professora destaca “quebra-cabeças, Jogo da Velha, Jogo da Memória, jogo dos erros”, sendo que entre estes, três também foram utilizados por esta pesquisa. Ela relata acreditar que “jogando a criança desenvolve a capacidade de raciocínio e contração e com isso há melhor desenvolvimento tanto em matemática, quanto nas outras disciplinas", demonstrando acreditar no proposto por esta dissertação. Observando a sala de aula, percebe-se que há um incentivo ao uso dos jogos, pois em todas as salas há uma grande variedade de jogos educativos disponibilizados pela direção da escola.

Ao responder sobre a reação dos alunos com relação aos jogos propostos, a professora disse que eles "comentaram sobre os jogos e aguardavam ansiosos a chegada da pesquisadora. Elas reagiram de maneira positiva, amavam os dias em que aconteciam os jogos. Foi uma experiência prazerosa.”. Este relato reforça a presença da ludicidade na pesquisa, demonstrando que as aulas despertaram o prazer dos alunos em jogar, e que ele o faziam por vontade própria, demonstrando a vontade da repetição.

Ao ser questionada sobre o desenvolvimento dos alunos, a professora coloca que, com relação à socialização, eles se tornaram mais amigos, solidários e independentes, além de aprender a competir.

Ao falar a respeito da aprendizagem e raciocínio dos alunos, a professora reconhece o desenvolvimento destes, relatando que "eles estão conseguindo se concentrar melhor, chegando à um melhor desempenho nas atividades". Por fim, a professora também reconhece 
desenvolvimento no que se refere à matemática, citando que os alunos estão “ buscando vários caminhos para chegar às soluções das atividades, estão resolvendo seus conflitos e situações problema de maneira independente".

A fala da professora confirma o observado nas aulas e através da avaliação inicial e final dos alunos. O trabalho com os jogos proporcionou aos alunos o desenvolvimento de diversas habilidades que influenciam na aprendizagem matemática, onde a professora também pode observar crescimento dos alunos. Os jogos fizeram com que os alunos ficassem mais atentos, concentrados e independentes, refletindo positivamente em sua aprendizagem e desenvolvimento. 


\section{CONCLUSÕES}

O desenvolvimento desta pesquisa possibilitou a reflexão sobre questões importantes envolvendo a aprendizagem dos alunos, em especial a aprendizagem matemática na educação infantil.

Inicialmente foi explorado o conceito de ludicidade. Após a pesquisa bibliográfica, concluiu-se que a ludicidade é um conceito subjetivo, que não está em um objeto, pessoa ou atividade, mas sim na relação do indivíduo com estes elementos. A ludicidade desperta o prazer da atividade, e faz com que a pessoa deseje repeti-la pelo prazer da repetição.

Também foi elaborado o conceito de Jogos de Reflexão Pura, sendo que este é um tema não muito trabalhado na literatura nacional, havendo um número reduzido de ocorrências nas pesquisas bibliográficas realizadas, o que o torna pouco conhecido por estudiosos e profissionais da educação. O estudo corroborou na proposição de quatro características básicas necessárias para classificar um jogo como Jogo de Reflexão Pura. Estes quesitos são: desenvolver estruturas matemáticas; não apresentar conteúdos específicos; promover a competição entre dois jogadores ou duas equipes; e não apresentar o aspecto do azar. Observando estes quesitos formou-se então o conceito de Jogos de Reflexão Pura como um tipo de jogos de estratégia construído sobre bases matemáticas, mas que não apresentam um conteúdo matemático específico, e que buscam promover a competição entre dois adversários.

Os conceitos trabalhados foram relacionados à aprendizagem matemática na educação infantil, observando-se e concluindo-se que os Jogos de Reflexão Pura poderiam desenvolver de forma lúdica diversas habilidades e estruturas essenciais para a aprendizagem matemática.

Partiu-se então para a escolha dos jogos, o que se se constituiu como uma difícil tarefa, visto que há poucas opções de jogos voltados para a faixa etária selecionada na pesquisa e, dentre estes, uma parcela ainda menor atende às características necessárias para ser considerado um Jogo de Reflexão Pura. Houve necessidade de selecionar jogos destinados para crianças maiores e adaptá-los para os alunos da educação infantil.

Escolhidos os jogos, foi realizado o contato com a escola. A equipe da escola selecionada recebeu a pesquisa proposta com disponibilidade e boa vontade, proporcionando todo o suporte necessário para o seu desenvolvimento. Além de disponibilizar o tempo e 
espaço para a pesquisa, sempre que necessário também eram fornecidos materiais, como folhas brancas, cartolinas e pinceis para quadro branco. $\mathrm{O}$ apoio da escola demonstrou o interesse de seus profissionais em proporcionar a evolução da educação e o fato de estarem sempre disponíveis a conhecer novos métodos e materiais para se trabalhar com a educação infantil.

Inicialmente a pesquisa deveria ser registrada em áudio, porém percebeu-se logo na primeira aula que o comportamento dos alunos inviabilizava tal registro. Além de as crianças falarem alto, provocando muito barulho em sala, as falas dos alunos eram pouco expressivas com relação ao jogo, sendo que o mais importante era observar suas ações. Assim, a gravação de áudio se mostrou ineficaz, sendo substituída pelo vídeo, o que foi essencial para a análise.

Através da análise das informações produzidas no decorrer da pesquisa foi possível chegar à resposta das questões que serviram como base para sua elaboração.

A primeira questão proposta era "como trabalhar com Jogos de Reflexão Pura em sala de aula?". A proposta inicial era trabalhar com uma turma convencional da educação infantil, composta por 24 alunos, porém, ao abordar a escola, o contato foi realizado com uma turma de inclusão, onde haviam 14 alunos matriculados. No decorrer de todo o processo a pesquisadora pode contar com o apoio da professora e, em diversas aulas, da auxiliar de turma, mas ficou claro que a quantidade de alunos é determinante para a dinâmica em sala. Apesar de estar com uma turma reduzida, com a agitação natural dos alunos houve dificuldade no acompanhamento de todas as crianças quando o jogo em duplas era distribuído. Percebe-se que a pesquisa poderia ter sido prejudicada se fosse em uma turma com 24 alunos, pois poderia comprometer a construção de dados e o acompanhamento dos alunos.

Para contornar a dificuldade de acompanhar os alunos no jogo em versão reduzida, a pesquisadora decidiu utilizar o jogo com toda a turma por mais tempo a cada aula. Nestes momentos era possível observar o modo como cada criança jogava e intervir quando necessário. Os momentos de jogos em duplas foram utilizados para observar como os alunos agiam autonomamente e planejar a intervenção da aula seguinte, que era aplicada quando os alunos estavam jogando em duplas. Em alguns momentos a pesquisadora chamava as duplas para jogar, podendo observar melhor cada aluno, sendo possível também intervir se necessário. 
Para que o jogo flua bem em sala esta é uma dinâmica que pode ser reaplicada. O uso do jogo em versão maior para que todos os alunos tivessem acesso e pudessem jogar juntos foi de grande valia para sua apresentação e desenvolvimento. Assim, foi possível acompanhar os alunos enquanto eles aprendiam as regras de um novo jogo e todos podiam ver e interagir com o material com facilidade. Os momentos com os jogos em versão menor eram importantes para que as crianças trabalhassem o que haviam aprendido, e para observar suas ações, mas sempre havia necessidade de voltar ao jogo em equipes para ampliar o conhecimento e desenvolvimento deles com relação à atividade proposta.

Assim, com base nesta pesquisa é possível afirmar que um modo efetivo de trabalhar com Jogos de Reflexão Pura é utilizando uma versão maior do jogo para introduzir as regras e reforça-las diariamente com os alunos, mas possibilitando momentos em que as crianças possam interagir e explorar o jogo de maneira independente.

Para responder à questão "de que modo Jogos de Reflexão Pura podem se constituir como uma ferramenta lúdica?", é necessário observar o comportamento dos alunos com relação às atividades propostas. Reforçando-se que a ideia de ludicidade está relacionada ao prazer que a atividade proporciona e ao desejo de repeti-la, foi possível perceber que o jogo despertou este sentimento nos alunos.

A partir das observações e relatos da professora é possível perceber que os alunos demonstravam gosto pelos jogos e pelas aulas, expressando ansiedade e entusiasmo enquanto aguardavam seu início. Tal fato também deixa claro o desejo de repetição dos jogos, visto que o sentimento permanecia mesmo com a retomada dos jogos, bem como a cobrança dos alunos de continuar o projeto após o seu término.

Quase todos momentos da pesquisa, tanto as avaliações quanto as aplicações de jogos, despertaram nos alunos o espírito lúdico. Porém, percebe-se que o desenvolvimento de um jogo que estava além da capacidade dos alunos, o jogo Mancala, não foi capaz de prender a atenção das crianças, que se cansaram e não quiseram retoma-lo na aula seguinte, não quiseram repeti-lo. A partir deste relato, pode-se concluir que uma característica importante para que o jogo seja considerado lúdico é estar adequado ao nível de desenvolvimento do jogador. O profissional que pretende trabalhar com este tipo de material deve estar disposto a analisar as reações dos seus alunos, lembrando que a imposição da atividade não condiz com a ludicidade. Com relação a esta pesquisa, a possibilidade de os alunos experimentarem um jogo novo e opinarem sobre este, solicitando a sua mudança, também pode ser visto como 
uma característica lúdica. O material apresentado no jogo Mancala despertou o interesse dos alunos, que desejaram interagir com ele. Mas no momento em que a atividade se tornou maçante, as crianças puderam optar por não mais realiza-la.

Assim, é possível afirmar que os Jogos de Reflexão Pura se constituem como uma ferramenta lúdica a medida que os alunos o consideram não uma tarefa escolar, mas sim um momento de diversão, pelo qual aguardavam ansiosamente a cada semana e participavam de forma espontânea, tendo a possibilidade de explorar e opinar sobre as atividades propostas.

Esta pesquisa também propõe a reflexão de como o uso de Jogos de Reflexão Pura pode auxiliar a aprendizagem matemática. Como já debatido, os Jogos de Reflexão Pura não trabalham conteúdos específicos, o que pode provocar a sensação de que não desenvolvem a matemática. Porém, tais jogos foram elaborados sobre bases matemáticas, sendo que desta forma, a sua execução já provoca a mobilização do pensamento matemático no indivíduo. Além disso, esta pesquisa pode comprovar que diversas habilidades e estruturas matemáticas são desenvolvidas por este tipo de atividade. Assim, os Jogos de Reflexão Pura não trabalham conteúdos matemáticos específicos, mas trabalha bases para que posteriormente os alunos possam construir e compreender tais conteúdos com mais facilidade.

Tal reflexão leva a resposta de outra questão proposta: quais são as estruturas matemáticas trabalhadas por meio dos Jogos de Reflexão Pura? Foi possível comprovar no decorrer desta pesquisa que muitas são as estruturas matemáticas trabalhadas pelos jogos propostos.

No decorrer das aulas os alunos mostraram inicialmente um desenvolvimento em sua postura com relação ao jogo. Estavam mais atentos e concentrados em sua execução e buscando meios de alcançar a vitória. O cuidado com o material entregue também apresentou desenvolvimento, comprovando o exposto por Negrine (2001) e Sommerhalder e Alves (2011) de que a habilidade de lidar com elementos lúdicos é desenvolvida a partir do contato dos alunos com estas.

Também era possível perceber a cada jogada a mobilização de habilidades que influenciam na aprendizagem matemática. Os alunos desenvolveram sua reflexão e atenção a cada jogo, bem como expressaram sua memória e apresentaram movimentos e jogadas onde eram evidentes a estratégia e o pensamento lógico.

Outras habilidades foram desenvolvidas em segundo plano, como era o caso da associação, pareamento e linguagem, usadas diariamente, mas de forma mais sutil. Por fim, os 
alunos tiveram oportunidade de trabalhar a discriminação visual e a contagem durante as atividades, apresentando no decorrer das aulas seu desenvolvimento com relação a estas.

Além das habilidades, era claro o desenvolvimento de algumas das estruturas matemáticas propostas por Lorenzato (2011): a correspondência, a comparação, a classificação, a sequenciação e a conservação. Tais habilidades eram trabalhadas através dos jogos e era perceptível o desenvolvimento dos alunos com relação a estas. As demais habilidades trabalhadas pelo autor não foram percebidas com tanta clareza pela pesquisadora, porém, esta acredita que, de alguma forma, a aplicação dos jogos também alcançou seu desenvolvimento, mesmo que em segundo plano.

Com a aplicação das avaliações iniciais e finais fica claro o desenvolvimento dos alunos com relação ao conceito de número. As atividades propostas foram realizadas com um maior aproveitamento na avaliação final do que na inicial. Assim, mesmo considerando o trabalho da professora com a turma no decorrer do período da pesquisa, pode-se afirmar que a aplicação dos jogos contribuiu para este resultado.

É importante também ressaltar que o desenvolvimento provocado pelos jogos propostos vai além do matemático. A mobilização das bases e estruturas promove habilidades que podem ser usadas na aquisição de conhecimentos em qualquer área. A capacidade de reflexão, atenção, memória e pensamento lógico, por exemplo, pode auxiliar na compreensão de qualquer conteúdo com que o aluno tenha contato, facilitando o seu aprendizado. As bases provocadas pelos Jogos de Reflexão Pura auxiliarão a estimular a aprendizagem do indivíduo por toda a vida.

Além destes aspectos, a linguagem, que não é uma habilidade essencialmente matemática, foi um elemento amplamente desenvolvido durante a pesquisa por meio da aquisição de novos vocabulários e o estímulo a criação e replicação de frases, bem como o próprio incentivo a participação para que os alunos expressassem suas opiniões.

Além da resposta às questões inicialmente propostas, a aplicação desta pesquisa proporcionou também outras reflexões.

O desenvolvimento do aluno Marcos, com necessidades educacionais especiais, merece destaque. $\mathrm{O}$ atendimento a alunos portadores de necessidade educacionais especiais não era o foco da presente pesquisa, mas ficou evidente que a aplicação de jogos também proporciona o seu desenvolvimento. $\mathrm{O}$ aluno em questão apresentou um grande avanço nas habilidades e estruturas analisadas, bem como uma relação de ludicidade com os jogos 
propostos. É importante, porém, colocar que tal desenvolvimento foi possível graças ao auxílio da monitora de classe, que se dispôs a trabalhar os jogos com o aluno. Assim, percebese que os Jogos de Reflexão Pura também podem ser utilizados para promover a aprendizagem dos alunos com necessidade educacionais especiais, desde que haja uma mediação adequada.

Como relatado anteriormente, esta pesquisa apresenta características da pesquisa-ação, e, desta forma, deve proporcionar ao pesquisador uma reflexão que provoque mudança em sua prática. Pode-se afirmar que este processo de reflexão e mudança da prática ocorriam em cada aula. A partir da observação da relação dos alunos com os jogos a pesquisadora modificava a dinâmica e o planejamento das aulas seguintes, adequando às necessidades dos alunos, o que impactou em uma mudança em sua prática, não apenas no decorrer do processo, mas também como profissional. Essa possibilidade de mudança é essencial em sala, o professor deve sempre buscar adequar sua prática para alcançar o aluno.

Percebe-se também a necessidade de prosseguimento da pesquisa, sendo possível analisar o alcance dos Jogos de Reflexão Pura para além do desenvolvimento matemático, buscando perceber como este pode auxiliar os alunos na aprendizagem das demais áreas do conhecimento.

Assim, esta pesquisa reforça a importância da ludicidade no ambiente escolar, evidenciando que os Jogos de Reflexão Pura são capazes de promover o espírito lúdico, mesmo em alunos da educação infantil, enquanto desenvolve a aquisição de estruturas e habilidades básicas para a aprendizagem matemática.

$\mathrm{O}$ ambiente criado pela pesquisadora, proporcionando uma relação afetiva de respeito e amizade entre ela e os alunos, além da possibilidade destes de expor suas ideias e agir segundo a sua vontade foi de grande importância para o desenvolvimento da ludicidade. Assim, os alunos puderam interagir com os jogos segundo a sua vontade, criando uma relação prazerosa e significativa, o que impactou na aprendizagem matemática. É importante ressaltar que, apesar de alcançar resultados significativos, esta pesquisa foi desenvolvida em um curto período de tempo, sendo que sua reaplicação em um período maior poderia promover a descoberta de novos aspectos sobre o desenvolvimento matemático proporcionado pelos jogos utilizados, visto que para a aprendizagem o aluno precisa de tempo, pois cada um se desenvolve a seu modo, segundo o seu ritmo. 
A aprendizagem está em constante desenvolvimento, e um ambiente estimulador, com atividades convidativas e desafiadoras é peça essencial neste processo. É neste contexto que o lúdico se insere, pois este permite ao aluno a experimentação e possibilidade de acertar ou errar sem culpa. Por meio do lúdico o professor assume o papel de mediador do conhecimento, pois passa a proporcionar espaços em que os alunos possam construir e experimentar, estimulando-os a aprender e a buscar o aprendizado.

A ludicidade tem a possibilidade de despertar o prazer do aluno pela aprendizagem. Por meio desta pesquisa, pode-se comprovar que não há necessidade de um ambiente rígido e impositor para que o aluno se desenvolva, sendo mais significativo e duradouro o conhecimento e desenvolvimento adquiridos por opção do sujeito.

Os Jogos de Reflexão Pura devem ser encarados pelos professores, não apenas da educação infantil, mas de todas etapas do ensino, como um valioso aliado na promoção da aprendizagem matemática, bem como uma possibilidade de promover uma relação prazerosa do aluno com esta área do conhecimento, frequentemente vista por eles com receio.

Por fim, este trabalho foi capaz de demonstrar, não apenas a importância de se trabalhar com a ludicidade em sala de aula, destacando que o aspecto lúdico atraia os alunos para a atividade e fazia com que eles desejassem repeti-la, ampliando assim o seu desenvolvimento, mas que é possível alcançar o espirito lúdico com o tipo de jogo escolhido. Concluiu-se também que os Jogos de Reflexão Pura podem contribuir com a aprendizagem matemática dos alunos da educação infantil de forma lúdica e significativa.

Promover o prazer de aprender deve ser a meta de todo profissional da educação, pois quando o aluno perceber o quão prazeroso pode ser o processo de aprendizagem, ele o buscará por si só. Neste processo o professor deve se enquadrar apenas como um mediador, que apresenta aos alunos elementos que o auxiliarão nesta jornada, possibilitando assim o desenvolvimento integral do indivíduo. 


\section{REFERÊNCIAS}

AZEVEDO, Priscila Domingues de. O conhecimento matemático na educação infantil: o movimento de um grupo de professoras em processo de formação continuada. $242 \mathrm{f}$. Tese (Doutorado em Educação) - Universidade Federal de São Carlos. São Paulo, 2012.

AZEVEDO, Priscila Domingues de. Educação matemática na infância: práticas pedagógicas de um grupo de professoras da educação infantil. Anais XI Enem. Curitiba: Sociedade Brasileira de Educação Matemática, 2013.

AZEVEDO, Priscila Domingues de. Narrativas de práticas pedagógicas de professoras que ensinam matemática na educação infantil. Bolema. São Paulo. v. 28, n. 49, p. 857-874. 2014.

BARBIER, René. A pesquisa-ação. Trad.: Lucie Didio. Brasília: Liber Livro, 2007.

BARROSO, Ana Brauna Souza. Jogos cooperativos na educação infantil e suas implicações para o espaço da sala de aula. 181 f. Dissertação (Mestrado em Educação) Universidade de Brasília. Brasília, 2016.

BORTONI-RICARDO, Stella Maris. O professor pesquisador: introdução à pesquisa qualitativa. São Paulo: Parábola, 2008.

BOSCARIOL, Fabiana. Uma proposta de software de educação matemática para educação infantil. 83 f. Dissertação (Mestrado em Educação) - Universidade Estadual de Campinas. São Paulo, 2004.

BRASIL. Ministério da Educação. Secretaria de Estado de Educação do Distrito Federal. Currículo em movimento da educação básica: educação infantil. Brasília: MEC, SEB, 2010.

BRENELLI, Rosely Palermo. O jogo como espaço para pensar: a construção de noções lógicas e aritméticas. 8. ed. São Paulo: Papirus, 2008.

BROUGÈRE, Gilles. A criança e a cultura lúdica. Em: KISHIMOTO, Tizuko Morchida (Org.). O brincar e suas teorias. São Paulo: Cengage Learning, 2014. 
CAILLOIS, Roger. Os jogos e os homens: a máscara e a vertigem. Trad.: José Garces Palha. Lisboa: Cotovia, 1967

CANI, Olímpio Prada; PEREIRA, Ryan Eduardo Tonet; MOSER, Cinara; SCOTINI, Ana Paula. Jogos matemáticos e a questão da reciclagem: um repensar indispensável à humanidade. Educação Matemática em Revista. n. 50. 2016.

CARCANHOLO, Flávia Pimenta de Souza. A importância dos jogos na perspectiva históricocultural para a aprendizagem e desenvolvimento da criança na educação infantil. Educação Matemática em Revista. n. 45. 2015.

CARNIEL, Ana Luiza; RENKEN, Artur; SCHNEIDER, Simone Vieira; FORTUNATO, Vaneide. Educação infantil e a matemática na alimentação saudável. Educação Matemática em Revista. n. 50. 2016.

CHIAROTTINO, Zélia Ramozzi. Piaget segundo seus próprios argumentos. Psicologia USP. São Paulo. v. 21, n. 1. São Paulo, 2010.

CUNHA, Nylse Helena Silva; NASCIMENTO, Sandra Kraft do. Brincando aprendendo e desenvolvendo o pensamento matemático. Petrópolis: Vozes, 2005.

FÁVERO, Maria Helena. Avaliação das competências e dificuldades conceituais sobre número. Curso de especialização em psicopedagogia clínica e institucional. Universidade de Brasília. Brasília, 2012.

FERNÁNDEZ, Alicia. O saber em jogo: a psicopedagogia proporcionando autorias de pensamento. Porto Alegre: Artes Médicas, 2001.

GIL, Antônio Carlos. Como elaborar projetos de pesquisa. 4. ed. São Paulo: Atlas, 2009.

GIL, Antônio Carlos. Métodos e técnicas de pesquisa social. 6. ed. São Paulo: Atlas, 2011.

GOMES, Luciano Carvalhais; BELLINI, Luzia Marta. Uma revisão sobre aspectos fundamentais da teoria de Piaget: possíveis implicações para o ensino de física. Revista Brasil Ensino. São Paulo. v. 31, n. 2. 2009. 
GRANDO, Regina Célia; NACARATO, Adair Mendes. Educadoras da infância pesquisando e refletindo sobre a própria prática em matemática. Educar. Curitiba. n. 30, p. 211-234. 2007.

HUIZINGA, Johan. Homo Ludens. Trad.: João Paulo Monteiro. São Paulo: Perspectiva, 2007.

KAMII, Constance. A Criança e o Número. 39. ed. Campinas: Papirus, 2012.

KISHIMOTO, Tizuko Morchida. Jogos tradicionais infantis: o jogo, a criança e a educação. Petrópolis: Vozes, 1993.

KISHIMOTO, Tizuko Morchida (Org.). Jogo, brinquedo, brincadeira e a educação. 4. ed. São Paulo: Cortez, 2000.

LORENZATO, Sergio. Educação infantil e percepção matemática. 3. ed. São Paulo: Autores Associados, 2011.

LÜDKE, Menga; ANDRÉ, Marli E. D. A. Pesquisa em Educação: Abordagens Qualitativas. São Paulo: EPU, 1986.

MACEDO, Lino de; PETTY, Ana Lúcia Sícoli; PASSOS, Norimar Christe. Os jogos: o lúdico na aprendizagem escolar. Porto Alegre: Artmed, 2005.

MELO, Glória Maria Leitão de Souza; BRANDÃO, Soraya Maria Barros de Almeida; ARRUDA, Maria do Socorro Araújo de. Matematicando na educação infantil: a prática docente e a ludicidade no ensino da matemática. Anais X Enem. Salvador: Sociedade Brasileira de Educação Matemática, 2010.

MENESTRINA, Tatiana Comiotto; MANDLER, Marnei Luis; LEONARDO, Pamela Paola. A educação infantil e o ensino de matemática: experiências piagetianas com crianças de cinco anos. Anais XI Enem. Curitiba: Sociedade Brasileira de Educação Matemática, 2013.

MEZZAROBA, Cristiane Dorst. Problemas de lógica como motivadores no fazer matemática no sexto ano. 145 f. Dissertação (Mestrado em Educação) - Universidade de Brasília. Brasília, 2009.

MIRANDA, Simão de. Oficina de ludicidade na escola. São Paulo: Papirus, 2014. 
MOREIRA, Marco Antônio. Teorias da aprendizagem. São Paulo: EPU, 1999.

MUNIZ, Cristiano Alberto. Brincar e jogar: enlaces teóricos e metodológicos no campo da educação matemática. Belo Horizonte: Autêntica, 2010.

NASCIMENTO, Noemia Fabíola Costa do. A resolução de problemas de estrutura aditiva por crianças da educação infantil: o uso de jogos e problemas escolares. $128 \mathrm{f}$. Dissertação (Mestrado em Educação) - Universidade Federal de Pernambuco. Recife, 2007.

NEGRINE, Airton. A ludicidade como ciência. Em: SANTOS, Santa Marli Pires dos (Org). A ludicidade como ciência. Rio de Janeiro: Vozes, 2001.

NUNES, Terezinha; BRYANT, Peter. Crianças fazendo matemática. Porto Alegre: Artmed, 1997.

PEREIRA, Aldaiza Sudré; MAFRA, José Ricardo e Souza. Pesquisa e produção de material de apoio regional aos docentes da educação infantil e séries iniciais. Anais $\mathbf{X}$ Enem. Salvador: Sociedade Brasileira de Educação Matemática, 2010.

PIAGET, Jean; GRÉCO, Pierre. Aprendizagem e conhecimento. São Paulo: Livraria Freita Bastos, 1974.

PIAGET, Jean. O estruturalismo. Trad.: Moacir Renato de Amorim. 3. ed. São Paulo: Difel, 1979.

PIAGET, Jean. Gênese das estruturas lógicas elementares. 3. ed. Rio de Janeiro: Zahar, 1983.

PIAGET, Jean. A formação do símbolo na criança: imitação, jogo e sonho, imagem e representação. 3. ed. Rio de Janeiro: LTC, 1990.

PIAGET, Jean. Seis estudos de psicologia. 25. ed. Rio de Janeiro: Forense Universitátia, 2015.

RODRIGUES, Neiva Inês. Matemática, educação infantil e jogos de linguagem: um estudo etnomatemático. 84 f. Dissertação (Mestrado em Educação) - Centro Universitário Univates. Lajeado, 2010. 
SAIZ, Irma. Dividir com dificuldade ou a dificuldade de dividir. Em: PARRA, Cecília; SAIZ, Irma (Orgs). Didática da matemática: reflexões psicopedagógicas. Porto Alegre: Artes Médicas, 1996.

SANDES, Joana Pereira. O desenho como representação do pensamento matemático da criança no início do processo de alfabetização. 115 f. Dissertação (Mestrado em Educação) - Universidade de Brasília. Brasília, 2009.

SILVA, Silem Santos. Matemática na infância: uma construção, diferentes olhares. 236 f. Dissertação (Mestrado em Educação) - Universidade de São Paulo. São Paulo, 2008.

SILVA, Ana Paula Perovano dos Santos; BORTOLOTI, Roberta D’Angela Menduni. Um estudo de caso sobre a matemática na alfabetização em Jequié - BA. Anais X Enem. Salvador: Sociedade Brasileira de Educação Matemática, 2010.

SOMMERHALDER, Aline; ALVES, Fernando Donizete. Jogo e a educação da infância: muito prazer em aprender. Curitiba: CRV, 2011.

SPADA, Arlene Buzatto Delabary. A construção de jogos de regras na formação dos professores de matemática. Dissertação (Mestrado em Educação) - Universidade de Brasília. Brasília, 2009.

TRIVINOS, Augusto Nibaldo Silva. Introdução à pesquisa em ciências sociais: a pesquisa qualitativa em educação. São Paulo: Atlas, 1987.

VIEIRA, Sônia. Como elaborar questionários. São Paulo: Atlas, 2009. 


\section{ANEXO A: QUADRO ORGANIZATIVO - LINGUAGEM MATEMÁTICA - CURRICULO EM MOVIMENTO DA EDUCAÇÃO BÁSICA (EDUCAÇÃO INFANTIL)}

\begin{tabular}{|c|c|c|c|c|}
\hline & & $\mathrm{CRE}$ & & $\begin{array}{l}\text { PRE- } \\
\text { ESCOLA }\end{array}$ \\
\hline & LINGUAGEIM MAIEIAAICA & $\begin{array}{l}0 \text { a } 2 \\
\text { anos }\end{array}$ & $\begin{array}{l}3 \\
\text { anos }\end{array}$ & $\begin{array}{l}4 \text { a } 5 \\
\text { anos }\end{array}$ \\
\hline & Nûmeros e Operaçōes & & & \\
\hline 岁 & Identificaçào e nomeação dos nùmeros. & & $\mathrm{x}$ & $\mathrm{X}$ \\
\hline & $\begin{array}{l}\text { Reconhecimento de números em vários portadores de } \\
\text { texto, diferenciando-os de outras marcas gráficas. }\end{array}$ & & $\mathrm{X}$ & $\mathrm{X}$ \\
\hline 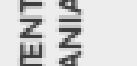 & Realizaçào de contagem oral em situaçoes diversas. & $\mathrm{X}$ & $\mathrm{X}$ & $\mathrm{X}$ \\
\hline 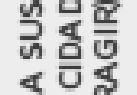 & $\begin{array}{l}\text { Desenvolvimento de nocòes simples de estimativa e de } \\
\text { cálculos mentais elementares. }\end{array}$ & & $\mathrm{X}$ & $\mathrm{X}$ \\
\hline 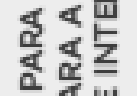 & $\begin{array}{l}\text { Desenvolvimento de estratégias pessoais para a resoluçào } \\
\text { de situaçdes problema. }\end{array}$ & $\mathrm{X}$ & $\mathrm{X}$ & $\mathrm{X}$ \\
\hline$\frac{1}{4} \frac{\alpha}{4}$ & $\begin{array}{l}\text { Atividades que trabalhem o raciocinio lógico por meio de } \\
\text { situaçoes-problema e histórias. }\end{array}$ & & $\mathrm{X}$ & $\mathrm{X}$ \\
\hline 马马ํํำ & $\begin{array}{l}\text { Representaçao com desenhos das estratégias utilizadas } \\
\text { para a resoluçăo de uma situaça proposta. }\end{array}$ & & & $\mathrm{X}$ \\
\hline 岁记 & Identificaçào de quantidades (oral e escrita numérica). & & $\mathrm{X}$ & $\mathrm{X}$ \\
\hline 员这出 & $\begin{array}{l}\text { Reconhecimento da ordem numérica (o que vem antes e } \\
\text { depois). }\end{array}$ & & $\mathrm{X}$ & $\mathrm{X}$ \\
\hline 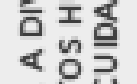 & $\begin{array}{l}\text { Reconhecimento da relaçào entre o número (falado e } \\
\text { escrito) e a quantidade que ele representa. }\end{array}$ & & $\mathrm{X}$ & $\mathrm{X}$ \\
\hline$\frac{\alpha}{\alpha} \frac{\bar{q}}{\underline{\alpha}}$ & $\begin{array}{l}\text { Desenvolvimento de noçòes de operaçdes matemáticas em } \\
\text { situaçodes concretas. }\end{array}$ & & $\mathrm{X}$ & $\mathrm{X}$ \\
\hline 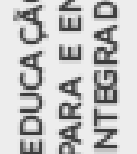 & $\begin{array}{l}\text { Realizaçào e compreensäo de agrupamentos, tendo como } \\
\text { critério a quantidade, priorizando algumas relaçóes como } \\
\text { um, nenhum, muito, pouco, tem mais, tem menos, tem a } \\
\text { mesma quantidade etc. }\end{array}$ & & $\mathrm{X}$ & $\mathrm{X}$ \\
\hline ïำ & $\begin{array}{l}\text { Comparaçào de quantidades, utilizando recursos pessoais, } \\
\text { como desenho e correspondéncia um a um. }\end{array}$ & & $\mathrm{x}$ & $\mathrm{X}$ \\
\hline$\sum_{0}^{ \pm}$ & Identificaçâo visual de alguns nùmeros. & & $\mathrm{X}$ & $\mathrm{X}$ \\
\hline$\stackrel{\mathbb{q}}{\stackrel{\leftrightarrow}{\rightleftarrows}}$ & $\begin{array}{l}\text { Utilizaçao das linguagens oral e pictórica para comunicar } \\
\text { ideias matemáticas. }\end{array}$ & & $\mathrm{X}$ & $\mathrm{X}$ \\
\hline ช̆ & Colocaça de um elemento em uma série ordenada $\left(1^{n}, 2^{n}, 3^{n} \ldots\right)$. & & $\mathrm{X}$ & $\mathrm{X}$ \\
\hline & Grandezas e Medidas & & & \\
\hline & $\begin{array}{l}\text { Desenvolvimento das noçes matemáticas de altura (alto } \\
\text { /baixo). largura (largo/fino), comprimento (comprido/ } \\
\text { curto), tamanho (grande/pequeno). peso (pesado /leve), } \\
\text { volume (cheio/ vazio), distancia (longe /perto), temperatura } \\
\text { (quente/frio) e tempo (rápido/ devagar), de maneira lúdica. }\end{array}$ & & $\mathrm{X}$ & $\mathrm{X}$ \\
\hline
\end{tabular}




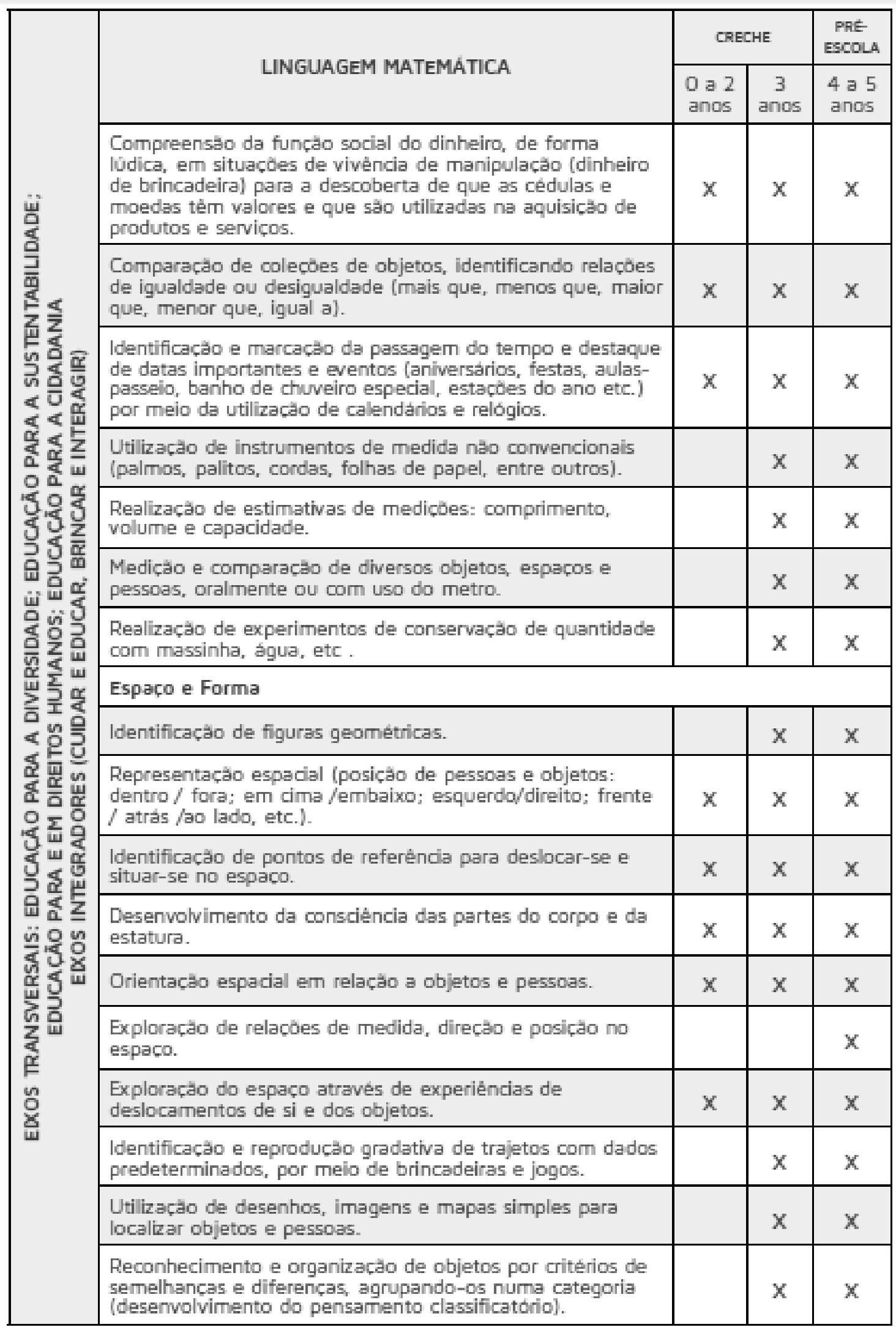




\begin{tabular}{|c|c|c|c|c|c|}
\hline \multirow{2}{*}{\multicolumn{2}{|c|}{ 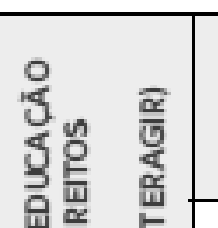 }} & \multirow{2}{*}{ LINGUAGEM MATEMÁTICA } & \multicolumn{2}{|c|}{ CRECHE } & \multirow{2}{*}{$\begin{array}{c}\begin{array}{c}\text { PRE- } \\
\text { ESCOLA }\end{array} \\
4 \text { a } 5 \\
\text { anos }\end{array}$} \\
\hline & & & $\begin{array}{l}0 \text { a } 2 \\
\operatorname{anos}\end{array}$ & $\begin{array}{c}3 \\
\text { anos }\end{array}$ & \\
\hline \multirow{8}{*}{\multicolumn{2}{|c|}{ 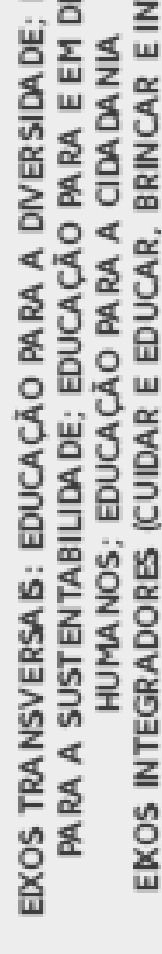 }} & $\begin{array}{l}\text { Seriaça de trés ou mais objetos, posicionando-os do } \\
\text { menor para o maior, do mais alto para o mais baixo, do } \\
\text { mais largo para o menos largo ou vice-versa. }\end{array}$ & & $x$ & $x$ \\
\hline & & $\begin{array}{l}\text { Identificacáo e manipulaça de formas geometricas no } \\
\text { cotidiano, por meio da observaço e manipulaça de } \\
\text { objetos, elementos da natureza, entre outros. }\end{array}$ & & $x$ & $x$ \\
\hline & & $\begin{array}{l}\text { Percepcào, identificaça e nomeaçäo das cores nos } \\
\text { ambientes, na natureza, nos materiais e nos objetos. }\end{array}$ & $x$ & $x$ & $x$ \\
\hline & & $\begin{array}{l}\text { Relaça entre a cor dos objetos e materiais e as cores } \\
\text { presentes na natureza. }\end{array}$ & & $\mathrm{x}$ & $\mathrm{x}$ \\
\hline & & \multicolumn{4}{|l|}{ Tratamento da Informaçăo } \\
\hline & & Auxilio na coleta e organizaçăo de dados. & & $x$ & $x$ \\
\hline & & $\begin{array}{l}\text { Participaça na construçăo de listas, tabelas e gráficos } \\
\text { (pictoricos e corporais), com o registro do professor em } \\
\text { variados suportes. }\end{array}$ & & & $\mathrm{x}$ \\
\hline & & $\begin{array}{l}\text { Analise oral de listas, tabelas e graficos (pictoricos e } \\
\text { corporais),com o registro do professor em variados } \\
\text { suportes. }\end{array}$ & & & $x$ \\
\hline
\end{tabular}




\section{ANEXO B: AVALIAÇÃO DAS COMPETÊNCIAS E DIFICULDADES CONCEITUAIS SOBRE O NÚMERO}

Trata-se de uma avaliação individual, que pode também ser utilizada na situação escolar. O material a ser utilizado é simples e o tempo para abordar cada um dos seus itens é pequeno.

\section{1- MATERIAL}

- 40 fichas da mesma cor e tamanho (ou grandes botões, tampinhas de garrafas todas da mesma cor e do mesmo tamanho, etc.).

- Três figurinhas (ou miniaturas encontradas em lojas de brinquedo: um gato, um cachorro e um coelhinho, ou semelhante).

- Uma caixa de reserva (uma caixa de sapato, por exemplo).

\section{2- DESCRIÇÃO DA SITUAÇÃO}

Devemos acomodar em uma mesa ou mesinha de pré-escola, ou no chão, com o sujeito preferencialmente acomodado ao nosso lado. Como em toda situação que envolve avaliação, precisamos ter o cuidado de estabelecer um contato inicial com o sujeito, adaptando nossa conversação a depender da sua idade. Uma conversa que gire em torno das atividades que mais gosta de fazer, por exemplo, pode, além de servir como um momento de descontração, nos fornecer dados complementares sobre a noção de tempo, espaço, quantidade, sobre a rotina cotidiana e também sobre os interesses do sujeito.

Durante o desenvolvimento da avaliação, item a item, devemos: lhe permitir toda e qualquer manipulação do material; questioná-lo para que justifique suas respostas; anotar suas ações com detalhes (contagens eventuais, etc.), suas justificativas, suas estratégias espontâneas ou provocadas, suas verbalizações, etc.

\section{3- DESENVOLVIMENTO DA PROVA}

\subsection{Configurações de partida}

Colocamos diante do sujeito três punhados de fichas que são distribuídas a cada uma das três figuras (aqui vamos nos referir a gato, cachorro e coelho) como abaixo. Uma caixa de reserva com 20 fichas é colocada à sua disposição.

- 2 fichas para o gato;

- 3 fichas para o cachorro;

- 7 fichas para o coelho.

\subsection{Os itens}

\section{Item 1 - DESCREVER A SITUAÇÃO}

"Aqui está o gato, aqui o cachorro e aqui o coelho; aqui estão as fichas de cada um. O que podemos dizer sobre o que temos aqui?". 


\section{Item 2 - QUEM TEM MAIS?}

"Quem tem mais fichas? Como você sabe?".

Em caso de dificuldade, colocam-se as mesmas questões diante de pares no lugar do trio: por exemplo, o gato e o cachorro. E se retoma a questão:

"Quem tem mais? Como você sabe?".

\section{Item 3 - TODOS PARECIDOS}

"O que podemos fazer para que todos eles tenham a mesma quantidade de fichas?".

Qualquer que seja a resposta do sujeito e, sobretudo no caso de sucesso, três saídas são propostas para incitá-lo a mudar a estratégia. Por exemplo, se ele juntar àquele que tem menos, perguntar: fichas?".

"Você poderia fazer diferente para que eles todos fiquem com o mesmo tanto de

Fonte: FÁVERO, Maria Helena. Avaliação das competências e dificuldades conceituais sobre número. Curso de especialização em psicopedagogia clínica e institucional. Universidade de Brasília. Brasília, 2012. 


\section{APÊNDICE A: PLANEJAMENTO DA PESQUISA (DIA A DIA)}

\begin{tabular}{|c|c|}
\hline DATA/HORA & JOGO/ATIVIDADE \\
\hline $16 / 03 / 2016$ & - Envio do TCLE aos pais. \\
\hline $\begin{array}{c}17 / 03 \mathrm{a} \\
24 / 03 / 2016\end{array}$ & $\begin{array}{l}\text { - Avaliação individual inicial dos alunos ( } 4 \text { a } 6 \text { alunos por dia, } 30 \\
\text { minutos com cada aluno). }\end{array}$ \\
\hline $\begin{array}{l}29 / 03 / 2016 \\
10 \mathrm{~h} \text { às } 11 \mathrm{~h}\end{array}$ & $\begin{array}{l}\text { Jogo: Jogo da Velha. } \\
\text { Atividade: Apresentar o jogo em tamanho grande na caixa surpresa. } \\
\text { Explicar as regras iniciais do jogo. Jogo com toda a turma. }\end{array}$ \\
\hline $\begin{array}{l}31 / 03 / 2016 \\
10 \mathrm{~h} \text { às } 11 \mathrm{~h}\end{array}$ & $\begin{array}{l}\text { Jogo: Jogo da Velha. } \\
\text { Atividade: Relembrar as regras iniciais com material em tamanho } \\
\text { grande e distribuir jogos em tamanho reduzido aos alunos para que } \\
\text { joguem em grupos. }\end{array}$ \\
\hline $\begin{array}{l}05 / 04 / 2016 \\
10 \mathrm{~h} \text { às } 11 \mathrm{~h}\end{array}$ & $\begin{array}{l}\text { Jogo: Jogo da Velha. } \\
\text { Atividade: Relembrar as regras iniciais com material em tamanho } \\
\text { grande e distribuir jogos em tamanho reduzido aos alunos para que } \\
\text { joguem em grupos. }\end{array}$ \\
\hline $\begin{array}{l}07 / 04 / 2016 \\
10 \mathrm{~h} \text { às } 11 \mathrm{~h}\end{array}$ & $\begin{array}{l}\text { Jogo: Jogo da Velha. } \\
\text { Atividade: Distribuir jogos em tamanho reduzido aos alunos para que } \\
\text { joguem em grupos. }\end{array}$ \\
\hline $\begin{array}{l}12 / 04 / 2016 \\
10 \mathrm{~h} \text { às } 11 \mathrm{~h}\end{array}$ & $\begin{array}{l}\text { Jogo: Jogo da Velha. } \\
\text { Atividade: Distribuir jogos em tamanho reduzido aos alunos para que } \\
\text { joguem em grupos. } \\
\text { Conversa em "rodinha" sobre o jogo proposto e possíveis } \\
\text { aprendizagens. }\end{array}$ \\
\hline $\begin{array}{l}14 / 04 / 2016 \\
10 \mathrm{~h} \text { às } 11 \mathrm{~h}\end{array}$ & $\begin{array}{l}\text { Jogo: Jogo da Memória. } \\
\text { Atividade: Apresentar o jogo em tamanho grande na caixa surpresa. } \\
\text { Explicar as regras iniciais do jogo. Jogo com toda a turma. }\end{array}$ \\
\hline $\begin{array}{l}19 / 04 / 2016 \\
10 \mathrm{~h} \text { às } 11 \mathrm{~h}\end{array}$ & $\begin{array}{l}\text { Jogo: Jogo da Memória. } \\
\text { Atividade: Relembrar as regras iniciais com material em tamanho } \\
\text { grande e distribuir jogos em tamanho reduzido aos alunos para que } \\
\text { joguem em grupos. }\end{array}$ \\
\hline $\begin{array}{l}\text { 20/04/2016 } \\
10 \mathrm{~h} \text { às } 11 \mathrm{~h}\end{array}$ & $\begin{array}{l}\text { Jogo: Jogo da Memória. } \\
\text { Atividade: Relembrar as regras iniciais com material em tamanho } \\
\text { grande e distribuir jogos em tamanho reduzido aos alunos para que } \\
\text { joguem em grupos. }\end{array}$ \\
\hline $\begin{array}{l}\text { 26/04/2016 } \\
10 \mathrm{~h} \text { às } 11 \mathrm{~h}\end{array}$ & $\begin{array}{l}\text { Jogo: Jogo da Memória. } \\
\text { Atividade: Distribuir jogos em tamanho reduzido aos alunos para que } \\
\text { joguem em grupos. }\end{array}$ \\
\hline $\begin{array}{l}28 / 04 / 2016 \\
10 \mathrm{~h} \text { às } 11 \mathrm{~h}\end{array}$ & $\begin{array}{l}\text { Jogo: Jogo da Memória. } \\
\text { Atividade: Distribuir jogos em tamanho reduzido aos alunos para que } \\
\text { joguem em grupos. }\end{array}$ \\
\hline $\begin{array}{l}03 / 05 / 2016 \\
10 \mathrm{~h} \text { às } 11 \mathrm{~h}\end{array}$ & $\begin{array}{l}\text { Jogo: Cara a Cara. } \\
\text { Atividade: Apresentar o jogo em tamanho grande na caixa surpresa. } \\
\text { Explicar as regras iniciais do jogo. Jogo com toda a turma. }\end{array}$ \\
\hline
\end{tabular}




\begin{tabular}{|c|c|}
\hline $\begin{array}{c}05 / 05 / 2016 \\
10 \mathrm{~h} \text { às } 11 \mathrm{~h}\end{array}$ & $\begin{array}{l}\text { Jogo: Cara a Cara. } \\
\text { Atividade: Relembrar as regras iniciais com material em tamanho } \\
\text { grande e distribuir jogos em tamanho reduzido aos alunos para que } \\
\text { joguem em grupos. }\end{array}$ \\
\hline $\begin{array}{c}\text { 10/05/2016 } \\
10 \mathrm{~h} \text { às } 11 \mathrm{~h}\end{array}$ & $\begin{array}{l}\text { Jogo: Cara a Cara. } \\
\text { Atividade: Relembrar as regras iniciais com material em tamanho } \\
\text { grande e distribuir jogos em tamanho reduzido aos alunos para que } \\
\text { joguem em grupos. }\end{array}$ \\
\hline $\begin{array}{c}12 / 05 / 2016 \\
10 h \text { às } 11 \mathrm{~h}\end{array}$ & $\begin{array}{l}\text { Jogo: Cara a Cara. } \\
\text { Atividade: Distribuir jogos em tamanho reduzido aos alunos para que } \\
\text { joguem em grupos. }\end{array}$ \\
\hline $\begin{array}{c}17 / 05 / 2016 \\
10 h \text { às } 11 \mathrm{~h}\end{array}$ & $\begin{array}{l}\text { Jogo: Cara a Cara. } \\
\text { Atividade: Distribuir jogos em tamanho reduzido aos alunos para que } \\
\text { joguem em grupos. }\end{array}$ \\
\hline $\begin{array}{c}\text { 19/05/2016 } \\
10 \text { às } 11 \mathrm{~h}\end{array}$ & $\begin{array}{l}\text { Jogo: Sudoku }(2 \times 2) \text {. } \\
\text { Atividade: Apresentação do jogo em tamanho grande na caixa } \\
\text { surpresa. Explicação das regras iniciais do jogo. Jogo com toda a } \\
\text { turma. }\end{array}$ \\
\hline $\begin{array}{c}24 / 05 / 2016 \\
10 h \text { às } 11 \mathrm{~h}\end{array}$ & $\begin{array}{l}\text { Jogo: Sudoku }(2 \times 2) \text {. } \\
\text { Atividade: Relembrar as regras iniciais com material em tamanho } \\
\text { grande e distribuir jogos em tamanho reduzido aos alunos para que } \\
\text { joguem em grupos. }\end{array}$ \\
\hline $\begin{array}{c}25 / 05 / 2016 \\
10 h \text { às } 11 \mathrm{~h}\end{array}$ & $\begin{array}{l}\text { Jogo: Sudoku }(3 \times 3) \text {. } \\
\text { Atividade: Apresentação do jogo em tamanho grande. Explicação das } \\
\text { regras iniciais do jogo. Jogo com toda a turma. }\end{array}$ \\
\hline $\begin{array}{l}31 / 05 / 2016 \\
10 \mathrm{~h} \text { às } 11 \mathrm{~h}\end{array}$ & $\begin{array}{l}\text { Jogo: Sudoku }(3 \times 3) \text {. } \\
\text { Atividade: Relembrar as regras iniciais com material em tamanho } \\
\text { grande e distribuir jogos em tamanho reduzido aos alunos para que } \\
\text { joguem em grupos. }\end{array}$ \\
\hline $\begin{array}{l}\text { 02/06/2016 } \\
10 \mathrm{~h} \text { às } 11 \mathrm{~h}\end{array}$ & $\begin{array}{l}\text { Jogo: Sudoku ( } 2 \times 2 \text { e } 3 \times 3) \text {. } \\
\text { Atividade: Distribuir jogos em tamanho reduzido aos alunos para que } \\
\text { joguem em grupos, deixando que eles escolham qual querem jogar. }\end{array}$ \\
\hline $\begin{array}{c}06 / 06 \text { a } \\
09 / 06 / 2016\end{array}$ & aliação individual final. \\
\hline $09 / 06 / 2016$ & sta com a professora \\
\hline
\end{tabular}




\section{APÊNDICE B: TERMO DE CONSENTIMENTO LIVRE E ESCLARECIDO (TCLE) -}

\section{ALUNOS}

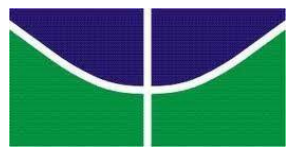

UNIVERSIDADE DE BRASÍLIA

FACULDADE DE EDUCAÇÃO

PROGRAMA DE PÓS-GRADUAÇÃO EM EDUCAÇÃO

\section{TERMO DE CONSENTIMENTO LIVRE E ESCLARECIDO}

Prezado Pai/Responsável,

Solicito autorização para desenvolver a pesquisa descrita abaixo, para a qual será necessária a colaboração voluntária de seu(sua) filho(a). Esta colaboração consistirá em participar da aplicação de jogos em sala e de entrevista e avaliações, o que ocorrerá no horário normal de aula. No decorrer da pesquisa poderão ser utilizados registros fotográficos e em áudio e vídeo, que servirão apenas para análise, não sendo divulgados.

Comprometo-me a fornecer todas as informações sobre a referida pesquisa antes, durante e após a construção dos dados.

Título da pesquisa: Jogos de Reflexão Pura como ferramenta lúdica para a aprendizagem matemática.

Pesquisadora responsável: Virgínia Perpetuo Guimarães Pin - FE/UnB

Orientador: Professor Dr. Antônio Villar Marques de Sá - FE/UnB

Garantia de acesso: em qualquer etapa do estudo você terá acesso à pesquisadora responsável pela pesquisa através do e-mail: virginiaperg@gmail.com.

Objetivo do estudo: Compreender os Jogos de Reflexão Pura na aprendizagem matemática da educação infantil.

Benefício da pesquisa: Contribuir para a aprendizagem matemática de alunos da educação infantil.

Custo/Reembolso: A participação será totalmente espontânea e gratuita não havendo nenhuma cobrança com o que será realizado ou pagamento por sua colaboração.

Sigilo: As informações fornecidas serão usadas somente para efeito desta pesquisa, sem identificação da instituição e dos interlocutores, isto é, os nomes não serão mencionados em nenhum momento e as imagens não serão divulgadas.

$\mathrm{Eu}$, RG abaixo assinado, responsável por , autorizo sua participação no projeto de pesquisa JOGOS DE REFLEXÃO PURA COMO FERRAMENTA LÚDICA PARA A PROMOÇÃO DA APRENDIZAGEM MATEMÁTICA, como sujeito. Fui devidamente informado(a) e esclarecido(a) pela pesquisadora sobre a pesquisa e os procedimentos nela envolvidos. Foi-me garantido que posso retirar meu consentimento a qualquer momento, sem qualquer penalidade ou interrupção do acompanhamento prestado ao sujeito pesquisado.

Brasília, DF, de de 2016. 


\section{APÊNDICE C: TERMO DE CONSENTIMENTO LIVRE E ESCLARECIDO (TCLE) - PROFESSORA}

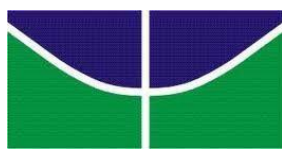

UNIVERSIDADE DE BRASÍLIA

FACULDADE DE EDUCAÇÃO

PROGRAMA DE PÓS-GRÁDUAÇÃO EM EDUCAÇÃO

\section{TERMO DE CONSENTIMENTO LIVRE E ESCLARECIDO}

Prezada Professora,

Solicito autorização para desenvolver a pesquisa descrita abaixo, para a qual será necessária a sua colaboração voluntária. Esta colaboração consistirá em disponibilizar momentos para que a pesquisadora interaja com a turma de sua responsabilidade e responder a uma entrevista. No decorrer da pesquisa poderão ser utilizados registros fotográficos e em áudio e vídeo, que servirão para análise, não sendo divulgados.

Comprometo-me a dar-lhe todas as informações sobre a referida pesquisa antes, durante e após a construção dos dados.

Título da pesquisa: Jogos de Reflexão Pura como ferramenta lúdica para a aprendizagem matemática.

Pesquisadora responsável: Virgínia Perpetuo Guimarães Pin - FE/UnB

Orientador: Professor Dr. Antônio Villar Marques de Sá - FE/UnB

Garantia de acesso: em qualquer etapa do estudo você terá acesso à pesquisadora responsável pela pesquisa através do e-mail: virginia.perg@gmail.com.

Objetivo do estudo: Compreender os Jogos de Reflexão Pura na aprendizagem matemática da educação infantil.

Benefício da pesquisa: Contribuir para a aprendizagem matemática de alunos da educação infantil.

Custo/Reembolso: A participação será totalmente espontânea e gratuita não havendo nenhuma cobrança com o que será realizado ou pagamento por sua colaboração.

Sigilo: As informações fornecidas serão usadas somente para efeito desta pesquisa, sem identificação da instituição e dos interlocutores, isto é, os nomes não serão mencionados em nenhum momento e as imagens não serão divulgadas.

$\mathrm{Eu}$, RG abaixo assinado, concordo em participar do projeto de pesquisa JOGOS DE REFLEXÃO PURA COMO FERRAMENTA LÚDICA PARA A PROMOÇÃO DA APRENDIZAGEM MATEMÁTICA, como sujeito. Fui devidamente informado(a) e esclarecido(a) pela pesquisadora sobre a pesquisa e os procedimentos nela envolvidos. Foi-me garantido que posso retirar meu consentimento a qualquer momento, sem qualquer penalidade ou interrupção do acompanhamento prestado ao sujeito pesquisado.

Brasília, DF, de de 2016. 


\section{APÊNDICE D: TERMO DE AUTORIZAÇÃO PARA REALIZAÇÃO DA PESQUISA}

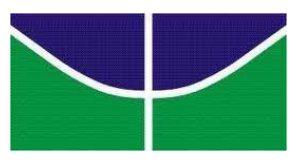

UNIVERSIDADE DE BRASÍLIA

FACULDADE DE EDUCAÇÃO

PROGRAMA DE PÓS-GRADUAÇÃO EMEDUCAÇÃO

\section{TERMO DE AUTORIZAÇÃO PARA REALIZAÇÃO DA PESQUISA}

Título da pesquisa: Jogos de Reflexão Pura como ferramenta lúdica para a aprendizagem matemática.

Pesquisadora responsável: Virgínia Perpetuo Guimarães Pin - FE/UnB

Orientador: Professor Dr. Antônio Villar Marques de Sá - FE/UnB

Garantia de acesso: em qualquer etapa do estudo você terá acesso à pesquisadora responsável pela pesquisa através do $e$-mail: virginia.perg@gmail.com.

Objetivo do estudo: Compreender os Jogos de Reflexão Pura na aprendizagem matemática da educação infantil.

$\mathrm{Eu}$,

diretora do Centro de Educação Infantil 04 de Sobradinho, RG $\mathrm{CPF}-$

AUTORIZO Virgínia Perpetuo Guimarães Pin, RG 2.662.108

SSP/DF, CPF 033.708.351-77, mestranda do programa de pós-graduação em educação da Universidade de Brasília, a aplicar jogos para uma turma de alunos desta instituição, e realizar observação e entrevista com os participantes que se voluntariarem para a realização do Projeto de Pesquisa identificado acima.

A pesquisadora acima qualificada se compromete a:

1. Submeter o Projeto de Pesquisa à aprovação do Comitê de Ética em Pesquisa com Seres Humanos.

2. Obedecer às disposições éticas de proteger os participantes da pesquisa, garantindolhes o máximo de benefícios e o mínimo de riscos.

3. Assegurar a privacidade das pessoas citadas nos documentos institucionais e/ou contatadas diretamente, de modo a proteger suas imagens, bem como garantir que não utilizarão as informações coletadas em prejuízo dessas pessoas e/ou da instituição.

Brasília, DF, de de 2016.

Assinatura e carimbo da diretora da instituição. 


\section{APÊNDICE E: ROTEIRO DE ENTREVISTA COM A PROFESSORA}

\section{Dados Pessoais}

1. Idade

2. Graduação

3. Titulação

4. Tempo de docência

5. Tempo de docência nesta instituição de ensino

\section{Questões}

1. Já utilizou ou utiliza jogos em suas aulas? Como os utiliza?

2. Já utilizou jogos para ensinar matemática na educação infantil? Quais jogos já utilizou?

3. Acha importante o uso dos jogos em sala de aula para a educação infantil? Por quê?

4. No decorrer das aulas os alunos comentaram sobre os jogos desenvolvidos com a pesquisadora? Como os alunos reagiram aos jogos?

5. Durante o tempo da pesquisa, notou desenvolvimento dos alunos:
a) quanto à socialização? Como?
b) quanto ao raciocínio e à aprendizagem?
c) quanto à educação matemática? 


\section{APÊNDICE F: CRONOGRAMA DE EXECUÇÃO DA PESQUISA (DIA A DIA)}

\begin{tabular}{|c|c|}
\hline DATA/HORA & JOGO/ATIVIDADE \\
\hline $23 / 03 / 2016$ & - Reunião de pais \\
\hline $24 / 03 / 2016$ & - Envio do TCLE aos pais. \\
\hline $\begin{array}{c}25,28 \mathrm{e} \\
29 / 03 / 2016\end{array}$ & $\begin{array}{l}\text { - Avaliação individual inicial dos alunos: } \\
\text { - } 1^{\circ} \text { Dia: } 4 \text { alunos; } \\
\text { - } 2^{\circ} \text { Dia: } 9 \text { alunos; } \\
\text { - } 3^{\circ} \text { Dia: } 1 \text { aluno. }\end{array}$ \\
\hline $\begin{array}{l}29 / 03 / 2016 \\
10 \mathrm{~h} \text { às } 11 \mathrm{~h}\end{array}$ & $\begin{array}{l}\text { Jogo: Jogo da Velha. } \\
\text { Atividade: Apresentar o jogo em tamanho grande na caixa surpresa. } \\
\text { Explicar as regras iniciais do jogo. Jogo com toda a turma. }\end{array}$ \\
\hline $\begin{array}{l}31 / 03 / 2016 \\
10 \mathrm{~h} \text { às } 11 \mathrm{~h}\end{array}$ & $\begin{array}{l}\text { Jogo: Jogo da Velha. } \\
\text { Atividade: Relembrar as regras iniciais com material em tamanho } \\
\text { grande e distribuir jogos em tamanho reduzido aos alunos para que } \\
\text { joguem em grupos. }\end{array}$ \\
\hline $\begin{array}{l}05 / 04 / 2016 \\
10 \mathrm{~h} \text { às } 11 \mathrm{~h}\end{array}$ & $\begin{array}{l}\text { Jogo: Jogo da Velha. } \\
\text { Atividade: Relembrar as regras iniciais com material em tamanho } \\
\text { grande e distribuir jogos em tamanho reduzido aos alunos para que } \\
\text { joguem em grupos. }\end{array}$ \\
\hline $\begin{array}{l}\text { 07/04/2016 } \\
10 \mathrm{~h} \text { às } 11 \mathrm{~h}\end{array}$ & $\begin{array}{l}\text { Jogo: Jogo da Velha. } \\
\text { Atividade: Relembrar as regras iniciais com material em tamanho } \\
\text { grande e distribuir jogos em tamanho reduzido aos alunos para que } \\
\text { joguem em grupos. }\end{array}$ \\
\hline $\begin{array}{l}12 / 04 / 2016 \\
10 \mathrm{~h} \text { às } 11 \mathrm{~h}\end{array}$ & $\begin{array}{l}\text { Jogo: Jogo da Velha. } \\
\text { Atividade: Competição entre meninos e meninas com toda a turma e } \\
\text { jogo em tamanho grande. }\end{array}$ \\
\hline $14 / 04 / 2016$ & - Aula adiada para a conclusão da confecção do jogo. \\
\hline $\begin{array}{l}19 / 04 / 2016 \\
10 \mathrm{~h} \text { às } 11 \mathrm{~h}\end{array}$ & $\begin{array}{l}\text { Jogo: Jogo da Memória. } \\
\text { Atividade: Apresentação do jogo em tamanho grande na caixa } \\
\text { surpresa. Explicação das regras iniciais do jogo. Jogo com toda a } \\
\text { turma. }\end{array}$ \\
\hline $20 / 04 / 2016$ & - Aula adiada por ser quarta-feira. \\
\hline $\begin{array}{l}26 / 04 / 2016 \\
10 \mathrm{~h} \text { às } 11 \mathrm{~h}\end{array}$ & $\begin{array}{l}\text { Jogo: Jogo da Memória. } \\
\text { Atividade: Relembrar as regras iniciais com material em tamanho } \\
\text { grande e distribuir jogos em tamanho reduzido aos alunos para que } \\
\text { joguem em duplas. }\end{array}$ \\
\hline $\begin{array}{l}28 / 04 / 2016 \\
10 \mathrm{~h} \text { às } 11 \mathrm{~h}\end{array}$ & $\begin{array}{l}\text { Jogo: Jogo da Memória. } \\
\text { Atividade: Relembrar as regras iniciais com material em tamanho } \\
\text { grande e distribuir jogos em tamanho reduzido aos alunos para que } \\
\text { joguem em duplas. }\end{array}$ \\
\hline $\begin{array}{l}\text { 03/05/2016 } \\
10 \mathrm{~h} \text { às } 11 \mathrm{~h}\end{array}$ & $\begin{array}{l}\text { Jogo: Jogo da Memória. } \\
\text { Atividade: Relembrar as regras iniciais com material em tamanho } \\
\text { grande e distribuir jogos em tamanho reduzido aos alunos para que } \\
\text { joguem em duplas. Jogo da pesquisadora com cada uma das duplas. }\end{array}$ \\
\hline
\end{tabular}




\begin{tabular}{|c|c|}
\hline $\begin{array}{c}\text { 05/05/2016 } \\
10 \text { h às } 11 \mathrm{~h}\end{array}$ & $\begin{array}{l}\text { Jogo: Jogo da Memória. } \\
\text { Atividade: Por opção dos alunos, competição entre meninos e meninas } \\
\text { com toda a turma e jogo em tamanho grande. }\end{array}$ \\
\hline $10 / 05 / 2016$ & Escola fechada por causa da infestação de escorpiões. \\
\hline $12 / 05 / 2016$ & Escola fechada por causa da infestação de escorpiões. \\
\hline $\begin{array}{c}\text { 17/05/2016 } \\
10 \mathrm{~h} \text { às } 11 \mathrm{~h}\end{array}$ & $\begin{array}{l}\text { Jogo: Cara a Cara. } \\
\text { Atividade: Apresentar jogo em tamanho grande na caixa surpresa. } \\
\text { Explicar das regras iniciais do jogo. Jogo com toda a turma. }\end{array}$ \\
\hline $\begin{array}{c}\text { 19/05/2016 } \\
10 \mathrm{~h} \text { às } 11 \mathrm{~h}\end{array}$ & $\begin{array}{l}\text { Jogo: Cara a Cara. } \\
\text { Atividade: Relembrar as regras iniciais com material em tamanho } \\
\text { grande, competição entre equipes. }\end{array}$ \\
\hline $\begin{array}{c}\text { 24/05/2016 } \\
10 \mathrm{~h} \text { às } 11 \mathrm{~h}\end{array}$ & $\begin{array}{l}\text { Jogo: Cara a Cara. } \\
\text { Atividade: Relembrar as regras iniciais com material em tamanho } \\
\text { grande e distribuir jogos em tamanho reduzido aos alunos para que } \\
\text { joguem em duplas. }\end{array}$ \\
\hline $\begin{array}{c}25 / 05 / 2016 \\
10 \mathrm{~h} \text { às } 11 \mathrm{~h}\end{array}$ & $\begin{array}{l}\text { Jogo: Cara a Cara. } \\
\text { Atividade: Relembrar as regras iniciais com material em tamanho } \\
\text { grande e distribuir jogos em tamanho reduzido aos alunos para que } \\
\text { joguem em duplas. }\end{array}$ \\
\hline $\begin{array}{c}31 / 05 / 2016 \\
10 h \text { às } 11 \mathrm{~h}\end{array}$ & $\begin{array}{l}\text { Jogo: Cara a Cara. } \\
\text { Atividade: Por opção dos alunos, competição entre meninos e meninas } \\
\text { com toda a turma e jogo em tamanho grande. }\end{array}$ \\
\hline 02/06/2016 & - Aula adiada para a conclusão da confecção do jogo. \\
\hline $\begin{array}{c}\text { 07/06/2016 } \\
10 \mathrm{~h} \text { às } 11 \mathrm{~h}\end{array}$ & $\begin{array}{l}\text { Jogo: Mancala. } \\
\text { Atividade: Apresentação do jogo em tamanho grande na caixa } \\
\text { surpresa. Explicação das regras iniciais do jogo. Jogo com toda a } \\
\text { turma. }\end{array}$ \\
\hline $\begin{array}{c}09 / 06 / 2016 \\
10 h \text { às } 11 \mathrm{~h}\end{array}$ & $\begin{array}{l}\text { Jogo: Mancala. } \\
\text { Atividade: Relembrar as regras iniciais com material em tamanho } \\
\text { grande e distribuir jogos em tamanho reduzido aos alunos para que } \\
\text { joguem em duplas. }\end{array}$ \\
\hline $\begin{array}{c}14 / 06 / 2016 \\
10 h \text { às } 11 \mathrm{~h}\end{array}$ & $\begin{array}{l}\text { Jogo: Pontinhos }(4 \times 4) \text {. } \\
\text { Atividade: Apresentação do jogo em tamanho grande. Explicação das } \\
\text { regras iniciais do jogo. Jogo com toda a turma. }\end{array}$ \\
\hline $\begin{array}{c}16 / 06 / 2016 \\
10 h \text { às } 11 \mathrm{~h}\end{array}$ & $\begin{array}{l}\text { Jogo: Pontinhos }(4 \times 4) \text {. } \\
\text { Atividade: Relembrar as regras iniciais com material em tamanho } \\
\text { grande e distribuir jogos em tamanho reduzido aos alunos para que } \\
\text { joguem em duplas. }\end{array}$ \\
\hline $\begin{array}{c}21 / 06 / 2016 \\
10 \mathrm{~h} \text { às } 11 \mathrm{~h}\end{array}$ & $\begin{array}{l}\text { Jogo: Pontinhos }(4 \times 4) \text {. } \\
\text { Atividade: Relembrar as regras iniciais com material em tamanho } \\
\text { grande e distribuir jogos em tamanho reduzido aos alunos para que } \\
\text { joguem em duplas. }\end{array}$ \\
\hline $\begin{array}{c}22 / 06 / 2016 \\
10 \mathrm{~h} \text { às } 11 \mathrm{~h}\end{array}$ & $\begin{array}{l}\text { Jogo: Pontinhos }(4 \times 4,5 \times 5) \text {. } \\
\text { Atividade: Relembrar as regras iniciais com material em tamanho } \\
\text { grande, introduzir o jogo } 5 \times 5 \text {. Distribuir jogos em tamanho reduzido } \\
\text { aos alunos para que joguem em duplas. }\end{array}$ \\
\hline
\end{tabular}




\begin{tabular}{|c|l|}
\hline $\begin{array}{c}23 / 06 / 2016 \\
10 \mathrm{~h} \text { às } 11 \mathrm{~h}\end{array}$ & $\begin{array}{l}\text { Jogo: Pontinhos }(4 \mathrm{x} 4,5 \times 5) . \\
\text { Atividade: Distribuir jogos em tamanho reduzido aos alunos para que } \\
\text { joguem em grupos, deixando que eles escolham qual querem jogar. }\end{array}$ \\
\hline $\begin{array}{c}\text { 28/06/2016 } \\
10 \mathrm{~h} \text { às } 11 \mathrm{~h}\end{array}$ & $\begin{array}{l}\text { Ultima aula: Disponibilizar todos os jogos trabalhados para que os } \\
\text { alunos, em duplas, escolham e joguem. } \\
\text { Conversa em rodinha sobre os jogos e desenho do jogo que mais } \\
\text { gostaram. }\end{array}$ \\
\hline $\begin{array}{l}30 / 06,05 \text { e } \\
27 / 07 / 2016\end{array}$ & $\begin{array}{r}- \text { Avaliação individual final. } \\
-1^{\circ} \text { Dia: } 9 \text { alunos; } \\
-2^{\circ} \text { Dia: } 3 \text { alunos; } \\
-3^{\circ} \text { Dia: } 1 \text { aluno. }\end{array}$ \\
\hline $07 / 07 / 2016$ & - Entrevista com a professora \\
\hline
\end{tabular}

